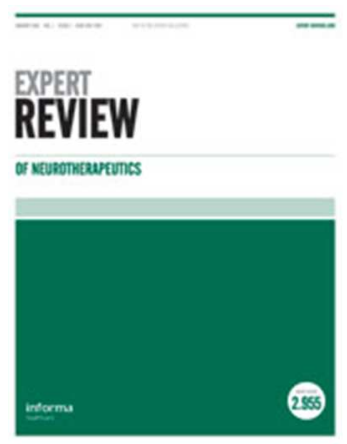

\title{
Technology-based assessment of motor and non-motor phenomena in Parkinson disease
}

\begin{tabular}{|r|l|}
\hline Journal: & Expert Review of Neurotherapeutics \\
\hline Manuscript ID & ERN-2018-0095.R1 \\
\hline Manuscript Type: & Reviews \\
\hline Keywords: & $\begin{array}{l}\text { biomarker, Parkinson, technology, motor symptoms, non-motor symptoms, } \\
\text { trial }\end{array}$ \\
\hline \multicolumn{2}{|l}{} \\
\hline
\end{tabular}

\section{SCHOLARONE"}

Manuscripts 


\title{
Technology-based assessment of motor and non-motor phenomena
}

\section{in Parkinson disease}

\author{
Aristide Merola ${ }^{1}$; Andrea Sturchio ${ }^{1}$; Stephanie Hacker ${ }^{1}$; Santiago Serna ${ }^{1}$; Joaquin A. Vizcarra ${ }^{1}$; \\ Luca Marsili $^{1}$; Alfonso Fasano ${ }^{2}$; Alberto J. Espay ${ }^{1}$ \\ 1. James J and Joan A Gardner Family Center for Parkinson's Disease and Movement \\ Disorders, Department of Neurology, University of Cincinnati, Cincinnati, OH, USA \\ 2. Edmond J. Safra Program in Parkinson's disease and the Morton and Gloria Shulman \\ Movement Disorders Clinic, Toronto Western Hospital, University of Toronto; Krembil \\ Brain Institute, Toronto, ON, Canada
}

\section{Corresponding Author:}

Aristide Merola,

UC Gardner Neuroscience Institute and Gardner Family Center for Parkinson's Disease and Movement Disorders, Department of Neurology, University of Cincinnati, 260 Stetson St, Ste 4300, Cincinnati, OH 45267-0525

Email: merolaae@ucmail.uc.edu 


\section{ABSTRACT}

Introduction: The increasing development and availability of portable and wearable technologies is rapidly expanding the field of technology-based objective measures (TOMs) in neurological disorders, including Parkinson disease (PD). Substantial challenges remain in the recognition of disease phenomena relevant to patients and clinicians, as well as in the identification of the most appropriate devices to carry out these measurements.

Areas Covered: The authors systematically reviewed PubMed for studies employing technology as outcome measures in the assessment of PD-associated motor and non-motor abnormalities.

Expert Commentary: TOMs minimize intra- and inter-rater variability in clinical assessments of motor and non-motor phenomena in PD, improving the accuracy of clinical endpoints. Critical unmet needs for the integration of TOMs into clinical and research practice are the identification and validation of relevant endpoints for individual patients, the capture of motor and non-motor activities from an ecologically-valid environment, the integration of various sensor data into an open-access, common-language platforms, and the definition of a regulatory pathway for approval of TOMs. The current lack of multi-domain, multi-sensor, smart technologies to measure in real time a wide scope of relevant changes remain a significant limitation for the integration of technology into the assessment of PD motor and non-motor functional disability.

Key words: biomarker, Parkinson, technology, motor symptoms, non-symptoms, trial 


\section{INTRODUCTION}

Parkinson disease (PD) is a multisystem neurodegenerative disorder resulting in a complex pattern of disability due to the impairment of both motor (i.e., tremor, bradykinesia, rigidity) and non-motor (i.e., cognition, sleep, autonomic) functional systems [1]. PD-associated clinical features are usually quantified by clinicians using validated clinical scales, such as the Movement Disorder Society Unified Parkinson's disease Rating Scale (MDS-UPDRS) [2], and the Non-Motor Symptoms Scale for Parkinson's disease (NMSS) [3]. These instruments, however, are prone to limitations such as subjectivity, inter-rater variability, and limited accuracy in capturing small variations between and within patients.

Technology advancements have expanded the application of a new generation of technologybased objective measures (TOMs) to detect and monitor a functional range critical for the comprehensive characterization and long-term monitoring of patients with PD [4,5]. TOMs may capture multiple motor activities, such as frequency and amplitude of movements, severity of tremor and dyskinesia, and extent of gait and postural impairment [6-8]. In addition, TOMs may characterize non-motor phenomena that cannot be captured by conventional clinical scales, such as sleep architecture, respiratory rate, beat-to-beat blood pressure changes, heart rhythm variability (HRV), and electroencephalographic (EEG) activity $[9,10]$.

By reducing the standard deviation of clinical endpoints and minimizing intra- and inter-rater variability in clinical assessments, TOMs have the potential to improve the quality of diagnostic definitions [11]. Multiple challenges, however, limit the integration of TOMs into the clinical and research practice, including standardization of extracted parameters, cost of technology, patient compliance [12], and risk of producing outcome measures that have little practical meaning to end-users $[13,14]$. In order to be purposeful, any measures of function need to represent variables that are important to patients and can be amenable to interventions by clinicians and researchers [15].

We sought to systematically review studies that employed technology for the evaluation of motor and non-motor phenomena in PD, appraising the extent of current integration of TOMs into the assessment of functional disability. 


\subsection{BODY}

This systematic review was conducted in accordance with the Preferred Reporting Items for Systematic Reviews and Meta-analyses (PRISMA) guidelines [16].

\subsubsection{Search Methods}

We searched PubMed for human studies published in English between January 1980 and June 2018 using a combination of free text and MeSH (Medical Subject Headings) for the following terms (Table e-1, online): Parkinson, smartphone, sensor, palm, computer, accelerometer, tablet, digital, electronic, microphone, gyroscope, actigraphy, gait analysis, voice analysis, pedometer, smartwatch, barometer, wearables, applications, apps, Wi-Fi, internet, Bluetooth, battery, touchscreen, camera, oximeter, facial recognition, tilt table, CANTAB, electroencephalogram, electrocardiogram, electromyogram, electronic diary, UPSIT. No restrictions were applied to gender, age, ethnicity, disease duration, or disease severity.

\subsubsection{Inclusion and Exclusion Criteria}

We included original studies employing TOMs as primary, secondary, or exploratory outcomes for the qualitative or quantitative assessment of symptoms, severity, and functional disability associated with PD. We excluded case reports, review articles, and studies using imaging, genetic, or corporal fluids (e.g., blood, cerebrospinal fluid) sampling technologies.

\subsubsection{Selection of studies}

Abstracts were independently reviewed for eligibility criteria by 2 investigators (A.S. and S.S.). Disagreements were anticipated to be settled by consensus among the authors. Duplicated studies were identified and excluded. The reference lists of selected articles were additionally screened for pertinent studies not included in the original search strategy.

\subsubsection{Data Extraction and Assessment of risk of bias}

The following data were extracted from eligible studies using a standardized form: a) year of publication; b) study design; c) study population; d) inclusion and exclusion criteria; e) primary and secondary outcome measures; f) results; and g) study limitations. Given the heterogeneity of study designs, we followed the Cochrane handbook recommendations and assessed the risk of 
bias of individual studies utilizing the National Heart, Lung, and Blood Institute tools (NHLBI) [17], as per the Cochrane handbook recommendations [18]. These tools are tailored to study types (i.e., cross-sectional, case-control, interventional) and include a qualitative, internal validity checklist ("Yes", "No", and "Non-applicable") for domains such as methodological pertinence, potential sources of bias, confounding, and adequacy of results for quality classification as "good," "fair," or "poor". In general, a "good" rating applies to studies with low risk of bias whose results are deemed valid; "fair" to studies susceptible to some biases but deemed insufficient to invalidate their results; and "poor" to studies with significant risk of bias.

\subsubsection{Data Analysis}

Included studies were categorized per functional domain investigated (motor vs. non-motor) and sorted per year of publication and technology employed. Results were summarized in tables and discussed in the text.

\subsection{Results}

The search strategy resulted in the identification of 2941 studies published between 1980 and 2018. A total of 2817 studies did not meet all inclusion criteria or were considered duplicates (Figure 1). Thus, we included 124 studies (106 cross-sectional, 11 case-control, and 7 prospective cohorts) which underwent data extraction and individual appraisal of the quality of evidence and risk of bias (Table e-2 and e-3, online).

There were 61 studies (59 cross-sectional and 2 case-control) employing TOMs for the assessment of qualitative measures of motor phenomena such as gait and postural instability ( $\mathrm{n}=$ 33 studies), bradykinesia ( $\mathrm{n}=13$ studies), tremor ( $\mathrm{n}=8$ studies), and rigidity ( $\mathrm{n}=7$ studies), and 63 studies (48 cross-sectional, 7 prospective cohort, and 8 case control) employing TOMs for the assessment of non-motor phenomena such as sleep disorders ( $\mathrm{n}=23$ studies), cognitive impairment ( $\mathrm{n}=18$ studies), dysautonomia ( $\mathrm{n}=12$ studies), visual deficits ( $\mathrm{n}=3$ studies), and voice analysis ( $\mathrm{n}=7$ studies) (Figure 2 ). The overall number of published studies integrating TOMs into the assessment of PD-associated motor (gait, postural stability, bradykinesia, rigidity, tremor) and non-motor (sleep, cognitive function, autonomic function, speech) deficits have steadily increased over the years (Figure 3). 


\subsubsection{Gait and Posture Stability}

Kinematic systems [19-43] and wearable sensors [44-50] were employed in the assessment of temporal (reaction time, gait cycle duration), spatial (step length, step height) and biomechanical (ankle torque, vertical landing force) variables of gait, and in the evaluation of gait strategies (i.e. number of steps, single versus multiple step response) during treadmill-based assessments or instrumented walking tests, such as the timed-up-and-go [29,38,44,46]. Balance and postural instability were assessed using force platforms [27,28,32,37,51-55] and wearable sensors [4448] (Figure 3) to measure the trajectory of the center of pressure (COP) and center of mass (COM) misplacement [22,23,28,32,53], as well as the trunk acceleration [53] during backwards pull [27,32,48,52], double task tests [51], and postural sway with eyes open and eyes closed [23]. Significant differences were observed in PD patients versus healthy controls in spatial and temporal gait variables [30,32,40,47,55], as well as in the postural response to external perturbations [32]. Gait parameters were also used to assess the progression of PD-associated gait and postural instability [22,24,25,27,28,37,45,47,52,53] and to assess the response to pharmacological [29] and non-pharmacological [20] therapies (Table 1).

Kinematic and EMG measurements were employed to assess turning and freezing of gait (FOG), evaluating both spatial and temporal gait parameters $[30,50,56]$, as well as the pattern of axial muscle activation during turns [33]. Freezers showed greater variability in stride length, stride time, and cadence compared to non-freezers [30,50,56] along with reduced thoracic adaptation to hip movements during gait and turns $[31,33,34]$, increased number of steps, prolonged turning time [57], and decreased range of motion in the ankle and hip joints immediately before FOG episodes [35].

\subsubsection{Bradykinesia and Rigidity}

Wearable sensors [58-60], infrared cameras [19,21,26,61,62], tablet-based measurements $[63,64]$, Diadochokinesimeter (65], dexterity pegboard [66], and light emitting diode (LED) photosensitive system [67] were used to evaluate amplitude, smoothness, and peak velocity of movements during standardized motor tasks such as finger tapping [21,61,63], pronationsupination [65], reach-to-grasp [19,26,62], wrist extension [59], goal directed movements [60], 
handwriting [64], and facial expression [67-69]. Muscle rigidity was evaluated using a dynamometer $[54,70]$.

There were similar reaction times and movement lengths in PD patients vs. healthy controls, but lower maximum speed and, consequently, longer execution time in PD [19,39]. TOMs accurately captured changes in transport time, wrist velocity, and arm acceleration during reach-to-grasp motor tasks [26,62]. Tablet-based measurements objectively quantified amplitude, velocity [64], and motor blocks during handwriting [63]. Wearable sensors were used to assess the effect of dopaminergic medications on speed and amplitude of movements, showing a more pronounced effect on the former [71]. Finally, optokinetic analyses were employed to assess orofacial movements, such as vertical jaw movements during speech [67] and hypomimia [68,69], showing sufficient accuracy in objectively capturing differences between PD patients and healthy controls (Table 2).

A study evaluated PD-associated trunk rigidity using a dynamometer to measure resistive torques during passive trunk flexion and extension [54]. The internal validity of this approach was confirmed by different authors reporting a direct correlation between dynamometer-based rigidity assessment and health-related quality of life in PD [70]. Unlike this study, however, most studies did not evaluate the extent to which changes measured by specific TOMs correlated with relevant changes as perceived by patients.

\subsubsection{Tremor}

Accelerometer- [72-75], gyroscope- [76,77], EMG- (72-74,78), kinematic- [72], and tabletbased [79] measurements were used to capture key phenomenological characteristics of tremor, namely frequency, amplitude, and variability under different testing conditions. TOMs effectively differentiated between parkinsonian, essential [76,77,79], and functional (psychogenic) tremors [78], and provided objective measurements of tremor severity in real-life condition using both wearable devices [74] and smartphone applications $[75,80]$.

TOMs were also employed in the detection of subclinical tremor [73] and the analysis of the different tremor components during resting, movement initiation, and decelerating phase of movement [72]. Innovative machine-learning algorithms have been recently developed to 
evaluate the variability of tremor in the time-domain during resting and motor activities [76,77] (Table 2).

\subsubsection{Speech}

Multi-dimensional voice software programs for acoustic analysis (i.e., Praat, a freeware developed by the University of Amsterdam) have been employed for the quantitative assessment of amplitude, prosody, speed, grammar, and fluency of speech during sustained-vowels phonation, alternating and sequential motion rates, and normal reading [81]. TOMs proved useful in sensitively capturing differences in speech between PD patients and healthy controls, including maximal phonation time, phonation quotient, percent jitter, percent shimmer, and noise-to-harmonic ratio [81-83], suggesting their employment in the diagnostic assessment of PD [84], monitoring of PD-associated functional disability [85], and prognostic assessment of functionally relevant outcomes such as cognitive decline [86]. An automated speech assessment has been proposed as part of a battery of test, including also posture analysis, gait assessment, finger tapping, and response time, to monitor PD symptoms at the home environment using commercially available smartphone applications [87] (Table 3).

\subsubsection{Sleep}

Sleep studies employed polysomnography (PSG) and actigraphy to evaluate the quality of sleep in PD [88-92], or to diagnose PD-associated conditions such as sleep apnea [92,93], REM sleep behavior disorders [92-99], sleep attacks [100-102], periodic limb movements [103], and nocturia [104]. The effect of pharmacological and non-pharmacological treatments on nocturnal sleep quality was also investigated using PSG [100,105-107].

Fragmented sleep architecture and reduced quality of sleep were found both in mild and advanced PD [108], with strong correlation between sleep efficiency, as measured by the PSG, and clinical measures of sleep quality, such as the Epworth sleepiness scale (EPSS), the PD sleep scale (PDSS), and the Pittsburgh Sleep Quality Index (PSQI) [109]. Additional studies evaluated the effect of pharmacological and non-pharmacological treatments on PD-associated quality of sleep, reporting an objective improvement in the architecture of sleep with advanced therapeutic 
options such as levodopa/carbidopa intestinal gel infusion (LCIG) [106] and subthalamic nucleus deep brain stimulation [107]. (Table 4).

\subsubsection{Cognitive Function}

Electroencephalographic (EEG) spectral analysis was used to evaluate cognitive function in PD [110-114], demonstrating a correlation between slow EEG rhythm in the temporo-occipital regions and poor performance on visuospatial tests $[113,115]$, as well as a correlation between increased risk of dementia and slow EEG activity in the posterior regions during REM sleep, and in the temporal regions during wakefulness [112,115-118]. Promising yet preliminary results were reported by studies investigating the application of evoked potential-based measures in the differential diagnosis of PD $[119,120]$ and in the assessment of PD-associated cognitive dysfunction [116-118,121-127], visual impairment [127-129], and behavioral disorders [130] (Table 3).

\subsubsection{Autonomic Function}

Cardiovascular and sweating autonomic testing, as well as HRV and 24-hour ambulatory blood pressure monitoring have been employed in the assessment of sympathetic [131,132] parasympathetic [132,133], and cholinergic autonomic function [10]. Significant differences were observed between PD and healthy controls suggesting a role for autonomic testing in the diagnostic classification of PD [134], characterization of patients at risk of poor functional outcome [135] or higher risk of dementia [136], and in distinguishing PD from atypical parkinsonian syndromes $[137,138]$. Recent studies also suggested that failure at the autonomic function testing might predict disease progression and survival in PD [139], as well as assist in the identification of patients expected to respond differentially to a range of treatments [140] (Table 5).

\section{CONCLUSION}

This systematic review showed that an increasing number of studies employed TOMs for the assessment of PD-associated motor and non-motor phenomena over the last two decades (Figure 5). A range of technologies were used to evaluate motor endpoints such as gait, balance, bradykinesia, tremor, rigidity, and speech, as well as non-motor endpoints such as sleep, 
cognition, and autonomic function. TOMs demonstrated the potential of capturing motor and non-motor phenomena with greater accuracy and reduced intra- and inter-rater variability than clinical scales and self-administered questionnaires. However, only a few studies correlated TOMs with patient-centered clinical scales, quality of life questionnaires, or handicap index. In addition, minimal clinically important differences have been estimated for a limited number of TOMs.

A possible limitation of our study consists of a searching strategy limited to published studies. We did not conduct searches in multiple databases, as well as Grey Literature or ongoing trials (e.g., clinicaltrials.gov). Thus, our conclusions do not take into consideration currently ongoing research endeavors.

\section{EXPERT COMMENTARY}

While substantially improving the accuracy of both motor and non-motor clinical endpoints in PD, ultimately resulting in improved diagnostics and monitoring of functional disability [11], the integration of TOMs into randomized controlled trials and routine clinical practice remains limited by several unresolved issues [141]. An important roadblock is the lack of a clear regulatory pathway from the FDA and the EMA for the routine employment of TOMs in both clinical and research settings. Less than $3 \%$ of ongoing clinical trials of neurodegenerative disorders have employed TOMs as an outcome measure. However, a survey from medical directors from pharmaceutical companies indicated that the majority of them are considering using TOMs in future clinical trials within the next five years [141].]. Also, a smartwatch for the monitoring of epileptic seizures was recently approved by regulatory agencies based on data demonstrating their accuracy and usefulness in clinical practice [142,143]. This preliminary experience encourages similar studies in the field of movement disorders.

The ideal outcome measure would be objective, exhibit minimal intra- and inter-operator variability, continuously capture relevant data in the patient's home environment, and sensitively capture small but meaningful changes over a prolonged period of time. Available TOMs meet some of these criteria but fail others, such as capturing motor and non-motor activities from an ecologically-valid environment. Currently, most of the gait and balance measures rely on tests 
assessing the patient's functional capacity (e.g., timed-up-and-go) rather than functional activity (e.g., continuous recording of natural unrestricted gait). In addition, the resolution of biomechanical sensors remains restricted to the anatomical area on which the sensors are applied, possibly yielding low quantitative agreement with the broader range of motor disability, quality of life, and other measurable patient-relevant endpoints [11,144].

The assessment of non-motor symptoms poses even more significant challenges due to the frequent use of cumbersome technologies such as PSG, EEG, or tilt table, which highlight the need for a tradeoff between the comprehensiveness of the assessment and their ecological validity. Simplified sleep measurements collected from an actigraphy may be preferred over the more accurate but less ecologically representative PSG [145]. A similar context applies to the evaluation of autonomic function. In a recent publication [146], we proposed that a $24 \mathrm{~h}-$ ambulatory blood pressure monitoring might be effectively employed as a screening test for cardiovascular autonomic neuropathy, a disabling comorbidity in PD with relevant socioeconomic impact [147]. Autonomic dysfunction remains under-recognized and under-treated in PD [148] in part because its ascertainment relies on cardiovascular autonomic testing available only in a few specialized laboratories. In conclusion, these findings highlight the urgent need for developing relatively simple and unobtrusive systems to monitor motor and non-motor endpoints in the home and community settings rather than during in-hospital evaluations.

A significant limitation consists of the lack of a multi-sensor, open-access, common-language platform combining the results of different sensors into a multi-dimensional TOM expressing a global measure of PD-associated functional disability. Although this unmet need has been reiterated by the Movement Disorders Society (MDS) in various international meetings and position papers [149], diagnostic and monitoring systems developed by different manufacturers continue to remain incompatible with one another. As a result, it is difficult or impossible to combine data gathered by different TOMs. This point represents one of the most critical areas of need, identified by the MDS Task Force for the Integration of Technology in PD as requiring further development. Only few studies have employed a smartphone application that integrates the capture of voice, posture, gait, finger tapping, and response time in the patient home 
environment, with high patient participation as well as sensitivity and specificity in the collected outcome measures [87].

\section{FIVE-YEAR VIEW}

Continuous improvements in technology are creating increasing opportunities for TOMs to improve self-management options and overall healthcare outcomes in PD. Thus, their integration into research and practice is expected to grow in the next five years. Critical challenges consist of validation of measures with patient-centered relevant endpoints, standardization of procedures, and approval by regulatory authorities.

\section{KEY ISSUES}

- Clinical scales for the assessment of Parkinson disease (PD) symptoms are prone to limitations such as subjectivity, inter-rater variability, and limited accuracy in capturing small variations within and between patients. A new generation of technology-based objective measures (TOMs) may provide a more accurate characterization of motor and non-motor phenomena associated with PD.

- We searched PubMed for human studies employing TOMs as primary, secondary, or exploratory outcomes for the qualitative or quantitative evaluation of PD-associated motor and non-motor symptoms. There were 61 studies assessing motor phenomena such as gait and postural instability $(\mathrm{n}=33$ studies), bradykinesia ( $\mathrm{n}=13$ studies $)$, tremor $(\mathrm{n}=8$ studies), and rigidity ( $\mathrm{n}=7$ studies), and 63 studies assessing non-motor phenomena such as sleep disorders ( $\mathrm{n}=23$ studies), cognitive impairment ( $\mathrm{n}=18$ studies), dysautonomia ( $\mathrm{n}=12$ studies), sensory deficits ( $\mathrm{n}=3$ studies), and voice analysis ( $\mathrm{n}=7$ studies).

- Although TOMs have the potential to significantly improve the accuracy of both motor and non-motor clinical endpoints, their integration into randomized controlled trials and routine clinical practice remains limited by several unresolved issues, including validation of patient-centered outcomes, standardization of measurements, and approval by regulatory authorities.

- While TOMs have not yet been shown to be superior to the clinical evaluation, their integration into research and practice is expected to substantially increase in the next five years and translate into enhanced care, better self-management options for PD patients, 
and overall improved healthcare outcomes. A survey from 12 medical directors from pharmaceutical companies indicated that $83 \%$ of them are considering using TOMs in future clinical trials within the next five years.

\section{Funding \\ This paper was not funded.}

\section{Declaration of interest}

A Merola is supported by the NIH (KL2 TR001426), has received speaker honoraria from CSL Behring and Cynapsus Therapeutics, and has received grant support from Lundbeck. A Fasano has received grants/research support from MJ Fox Foundation, University of Toronto, McLaughlin Centre; has received honoraria or consultation fees from AbbVie, Boston Scientific, Chiesi Farmaceutici, Ipsen, Medtronic, Novartis, TEVA Canada, UCB Pharma; and has participated in sponsored advisory boards for AbbVie, Boston Scientific, and Ipsen. AJ Espay is supported by the NIH, has received grant support from CleveMed/Great Lakes Neurotechnologies, Davis Phinney Foundation, and MJ Fox Foundation; was an investigator in Chelsea-sponsored studies, has acted as a scientific advisor to Lundbeck, and is marketer for Droxidopa but has no financial interest in either company. They have received personal compensation as a consultant/advisory board member for Solvay, Abbott, Chelsea Therapeutics, TEVA, Impax, Merz, Lundbeck, and Eli Lilly; has received honoraria from TEVA, UCB, the AAN, and the Movement Disorder Society; and publishing royalties from Lippincott Williams \& Wilkins, Cambridge University Press, and Springer. The authors have no further conflicts of interest to declare.

\section{Reviewer disclosures}

Peer reviewers on this manuscript have no relevant financial or other relationships to disclose. 


\author{
REFERENCES \\ Papers of special note have been highlighted as: \\ * of interest \\ ** of considerable interest
}

[1] Poewe W, Seppi K, Tanner CM, et al. Parkinson disease. Nat Rev Dis Prim 2017;3:17013

[2] Goetz CG, Stebbins GT, Wolff D, et al. Testing objective measures of motor impairment in early Parkinson's disease: Feasibility study of an at-home testing device. Mov Disord. 2009;24:551-6

[3] Martinez-Martin P, Chaudhuri KR, Rojo-Abuin JM, et al. Assessing the non-motor symptoms of Parkinson's disease: MDS-UPDRS and NMS Scale. Eur J Neurol. 2015;22:37-43

**Assessment of Parkinson's disease-associated symptoms using wearables.

[4] Roy SH, Cole BT, Gilmore LD, et al. High-resolution tracking of motor disorders in Parkinson's disease during unconstrained activity. Mov Disord 2013;28:1080-7

[5] Zhan A, Mohan S, Tarolli C, et al. Using Smartphones and Machine Learning to Quantify Parkinson Disease Severity. JAMA Neurol 2018; 75:876-80

[6] Aghanavesi S, Nyholm D, Senek M, et al. A smartphone-based system to quantify dexterity in Parkinson's disease patients. Informatics Med Unlocked. 2017;9:11-7

[7] Kostikis N, Hristu-Varsakelis D, Arnaoutoglou M, et al. A Smartphone-Based Tool for Assessing Parkinsonian Hand Tremor. IEEE J Biomed Heal Informatics. 2015;19:1835-42

[8] Haubenberger D, Kalowitz D, Nahab FB, et al. Validation of digital spiral analysis as outcome parameter for clinical trials in essential tremor. Mov Disord 2011;26:2073-80

[9] Naismith SL, Rogers NL, Mackenzie J, et al. The relationship between actigraphically defined sleep disturbance and REM sleep behavior disorder in Parkinson's Disease. Clin Neurol Neurosurg. 2010;112:420-3 
[10] Vichayanrat E, Low DA, Iodice V, et al. Twenty-four-hour ambulatory blood pressure and heart rate profiles in diagnosing orthostatic hypotension in Parkinson's disease and multiple system atrophy. Eur J Neurol 2017;24:90-7

[11] Maetzler W, Domingos J, Srulijes K, et al. Quantitative wearable sensors for objective assessment of Parkinson's disease. Mov Disord 2013;28:1628-37

[12] Stone AA, Shiffman S, Schwartz JE, et al. Patient compliance with paper and electronic diaries. Control Clin Trials 2003;24:182-99

[13] Hobart, J. C., Cano, S. J., Zajicek, J. P., et al. Rating scales as outcome measures for clinical trials in neurology: Problems, solutions, and recommendations. Lancet Neurology 2007;6;1094105

[14] Broderick JE. Electronic Diaries: Appraisal and Current Status. Pharmaceut Med. 2008;22:69-74

[15] Food and Drug Administration 2009. Patient-reported outcome measures: Use in medicinal product development to support labelling claims. Washington, DC

[16] Moher D, Liberati A, Tetzlaff J, et al., PRISMA Group. Preferred reporting items for systematic reviews and meta-analyses: the PRISMA statement. Ann Intern Med. 2009;151:264-9

[17] NHLBI, Research Triangle Institute International. National Heart, Lung, and Blood Institute Quality Appraisal Tools [online]. Available at: https://www.nhlbi.nih.gov/health-topics/study quality-assessment-tools. Accessed June 14, 2018

[18] Higgins JPT, Green S, editors. Cochrane Handbook for Systematic Reviews of Interventions [online]. 5.1.0. The Cochrane Collaboration; 2011. Available at: www.cochrane-handbook.org. Accessed June 15, 2018

\section{**Assessment of gait and posture in Parkinson's disease using technology-based objective measures.}


[19] Kelly VE, Hyngstrom AS, Rundle MM, et al. Interaction of levodopa and cues on voluntary reaching in Parkinson's disease. Mov Disord. 2002;17:38-44

[20] Stolze H, Klebe S, Poepping M, et al. Effects of bilateral subthalamic nucleus stimulation on parkinsonian gait. Neurology. 2001;57:144-6

[21] Johnson MT, Mendez A, Kipnis AN, et al. Acute effects of levodopa on wrist movement in Parkinson's disease. Kinematics, volitional EMG modulation and reflex amplitude modulation. Brain. 1994;117:1409-22

[22] Merello M, Fantacone N, Balej J. Kinematic study of whole body center of mass position during gait in Parkinson's disease patients with and without festination. Mov Disord. 2010;25:747-54

[23] Martin M, Shinberg M, Kuchibhatla M, et al. Gait initiation in community-dwelling adults with Parkinson disease: comparison with older and younger adults without the disease. Phys Ther. 2002;82:566-77

[24] Chomiak T, Pereira FV, Meyer N, et al. A new quantitative method for evaluating freezing of gait and dual-attention task deficits in Parkinson's disease. J Neural Transm (Vienna). 2015;122:1523-31

[25] Dillmann U, Holzhoffer C, Johann Y, et al. Principal Component Analysis of gait in Parkinson's disease: relevance of gait velocity. Gait Posture. 2014;39:882-7

[26] Rand MK, Lemay M, Squire LM, et al. Control of aperture closure initiation during reachto-grasp movements under manipulations of visual feedback and trunk involvement in Parkinson's disease. Exp Brain Res. 2010;201:509-25

[27] Kim S, Horak FB, Carlson-Kuhta P, et al. Postural feedback scaling deficits in Parkinson's disease. J Neurophysiol. 2009;102:2910-20

[28] Carpinella I, Crenna P, Calabrese E, et al. Locomotor function in the early stage of Parkinson's disease. IEEE Trans Neural Syst Rehabil Eng. 2007;15:543-51 
[29] Conradsson D, Paquette C, Lökk J et al. Pre- and unplanned walking turns in Parkinson's disease - Effects of dopaminergic medication. Neuroscience. 2017;341:18-26

[30] Barbe MT, Amarell M, Snijders AH, et al. Gait and upper limb variability in Parkinson's disease patients with and without freezing of gait. J Neurol. 2014;261:330-42

[31] Van Emmerik RE, Wagenaar RC, Winogrodzka A, et al. Identification of axial rigidity during locomotion in Parkinson disease. Arch Phys Med Rehabil.1999;80:186-91

[32] McVey MA, Stylianou AP, Luchies CW, et al. Early biomechanical markers of postural instability in Parkinson's disease. Gait Posture. 2009;30:538-42

[33] Hong M, Perlmutter JS, Earhart GM. A kinematic and electromyographic analysis of turning in people with Parkinson disease. Neurorehabil Neural Repair. 2009;23:166-76

[34] Huxham F, Baker R, Morris ME, et al. Head and trunk rotation during walking turns in Parkinson's disease. Mov Disord. 2008;23:1391-7

[35] Alice N, Fabienne C, Anne-Marie W, et al. Does freezing in Parkinson's disease change limb coordination? A kinematic analysis. J Neurol. 2007;254:1268-77

[36] Hong M, Perlmutter JS, Earhart GM. Podokinetic after-rotation in Parkinson disease. Brain Res. 2007;1128:99-106

[37] Svehlík M, Zwick EB, Steinwender G, et al. Gait analysis in patients with Parkinson's disease off dopaminergic therapy. Arch Phys Med Rehabil. 2009;90:1880-6

[38] Son M, Youm C, Cheon S, et al. Evaluation of the turning characteristics according to the severity of Parkinson disease during the timed up and go test. Aging Clin Exp Res. 2017;29:1191-9

[39] Fimbel E, Dubarry AS, Philibert M, et al. Event identification in movement recordings by means of qualitative patterns. Neuroinformatics. 2003;1:239-57

[40] Cho C, Kunin M, Kudo K, et al. Frequency-velocity mismatch: a fundamental abnormality in parkinsonian gait. J Neurophysiol. 2010;103:147889 
[41] Ferrarin M, Lopiano L, Rizzone M, et al. Quantitative analysis of gait in Parkinson's disease: a pilot study on the effects of bilateral sub thalamic stimulation. Gait Posture. 2002;16:135-48

[42] Ferrarin M, Rizzone M, Bergamasco B, et al. Effects of bilateral subthalamic stimulation on gait kinematics and kinetics in Parkinson's disease Exp Brain Res. 2005;160:517-27

[43] Johnsen EL, Sunde N, Mogensen PH et al. MRI verified STN stimulation site-gait improvement and clinical outcome. Eur J Neurol. 2010;17:746-53

[44] Salarian A, Horak FB, Zampieri C, et al. iTUG, a sensitive and reliable measure of mobility. IEEE Trans Neural Syst Rehabil Eng. 2010;18:303-10

[45] Parisi F, Ferrari G, Giuberti M, et al. Body-Sensor-Network-Based Kinematic Characterization and Comparative Outlook of UPDRS Scoring in Leg Agility, Sit-to-Stand, and Gait Tasks in Parkinson's Disease. IEEE J Biomed Health Inform. 2015;19:1777-93

[46] Zampieri C, Salarian A, Carlson-Kuhta P, et al. Assessing mobility at home in people with early Parkinson's disease using an instrumented Timed Up and Go test. Parkinsonism Relat Disord. 2011;17:277-80

[47] Schlachetzki JCM, Barth J, Marxreiter F, et al. Wearable sensors objectively measure gait parameters in Parkinson's disease. PLoS One. 2017;12:e0183989

[48] Pasluosta CF, Barth J, Gassner H, et al. Pull Test estimation in Parkinson's disease patients using wearable sensor technology. Conf Proc IEEE Eng Med Biol Soc. 2015;2015:3109-12

[49] Cantiniaux S, Vaugoyeau M, Robert D, et al. Comparative analysis of gait and speech in Parkinson's disease: hypokinetic or dysrhythmic disorders? J Neurol Neurosurg Psychiatry. 2010;81:177-84

[50] Moore ST, Yungher DA, Morris TR, et al. Autonomous identification of freezing of gait in Parkinson's disease from lower-body segmental accelerometry. J Neuroeng Rehabil. 2013;10-19

[51] Doan JB, Whishaw IQ, Pellis SM, et al. Challenging context affects standing reach kinematics among Parkinson's disease patients. Behav Brain Res. 2010;214:135-41 
[52] Ganesan M, Pal PK, Gupta A, Sathyaprabha TN. Dynamic posturography in evaluation of balance in patients of Parkinson's disease with normal pull test: concept of a diagonal pull test. Parkinsonism Relat Disord. 2010;16:595-9

[53] Mancini M, Zampieri C, Carlson-Kuhta P, et al. Anticipatory postural adjustments prior to step initiation are hypometric in untreated Parkinson's disease: an accelerometer-based approach. Eur J Neurol. 2009;16:1028-34

[54] Mak MK, Wong EC, Hui-Chan CW. Quantitative measurement of trunk rigidity in parkinsonian patients. J Neurol. 2007;254:202-9.

[55] Bleuse S, Cassim F, Blatt JL, et al. Anticipatory postural adjustments associated with arm movement in Parkinson's disease: a biomechanical analysis. J Neurol Neurosurg Psychiatry. 2008;79:881-87

[56] Pham TT, Moore ST, Lewis SJG, et al. Freezing of Gait Detection in Parkinson's Disease: A Subject-Independent Detector Using Anomaly Scores. IEEE Trans Biomed Eng. 2017;64:271928

[57] Stack E, Ashburn A. Dysfunctional turning in Parkinson's disease. Disabil Rehabil. 2008;30:1222-9

\section{**Assessment of Parkinson's disease-associated bradykinesia and rigidity using technology-based objective measures.}

[58] Kotschet K, Johnson W, McGregor S, et al. Daytime sleep in Parkinson's disease measured by episodes of immobility. Parkinsonism Relat Disord. 2014;20:578-83

[59] Rabelo AG, Neves LP, Paixão APS et al. Objective Assessment of Bradykinesia Estimated from the Wrist Extension in Older Adults and Patients with Parkinson's Disease. Ann Biomed Eng. 2017;45:2614-25

[60] Summa S, Tosi J, Taffoni F, et al. Assessing bradykinesia in Parkinson's disease using gyroscope signals. IEEE Int Conf Rehabil Robot. 2017;2017:1556-61 
[61] Jobbágy A, Harcos P, Karoly R, et al. Analysis of finger-tapping movement.J Neurosci Methods. 2005;141:29-39

[62] Castiello U, Bennett KM, Bonfiglioli C, et al. The reach-to-grasp movement in Parkinson's disease before and after dopaminergic medication. Neuropsychologia. 2000;38:46-59

[63] Popovic MB, Dzoljic E, Kostic V. A method to assess hand motor blocks in Parkinson's disease with digitizing tablet. Tohoku J Exp Med. 2008;216:317-24

[64] Heremans E, Nackaerts E, Broeder S, et al. Handwriting Impairments in People With Parkinson's Disease and Freezing of Gait. Neurorehabil Neural Repair. 2016;30:911-9

[65] Müller T, Harati A. Diadochokinetic movements differ between patients with Parkinson's disease and controls. J Neural Transm (Vienna). 2010;117:189-95

[66] Van Gilst MM, van Mierlo P, Bloem BR, et al. Quantitative Motor Performance and Sleep Benefit in Parkinson Disease. Sleep. 2015;38:1567-73

[67] Svensson P, Henningson C, Karlsson S. Speech motor control in Parkinson's disease: a comparison between a clinical assessment protocol and a quantitative analysis of mandibular movements. Folia Phoniatr (Basel). 1993;45:157-64

[68] Ricciardi L, Bologna M, Morgante F, et al. Reduced facial expressiveness in Parkinson's disease: A pure motor disorder? J Neurol Sci. 2015;358:125-30.

[69] Bologna M, Berardelli I, Paparella G, et al. Altered Kinematics of Facial Emotion Expression and Emotion Recognition Deficits Are Unrelated in Parkinson's Disease. Front Neurol. 2016;7:230

[70] Cano-de-la-Cuerda R, Vela-Desojo L, Miangolarra-Page JC, et al. Isokinetic dynamometry as a technologic assessment tool for trunk rigidity in Parkinson's disease patients.

NeuroRehabilitation. 2014;35:493-501

[71] Espay AJ, Beaton DE, Morgante F, et al. Impairments of speed and amplitude of movement in Parkinson's disease: a pilot study. Mov Disord. 2009;24:1001-8 


\section{**Assessment of Parkinson's disease-associated tremor using technology-based objective measures.}

[72] Wenzelburger R, Raethjen J, Löffler K, et al. Kinetic tremor in a reach-to-grasp movement in Parkinson's disease. Mov Disord. 2000;15:1084-94

[73] Vaillancourt DE, Newell KM. The dynamics of resting and postural tremor in Parkinson's disease. Clin Neurophysiol. 2000;111:2046-56

[74] Jeon H, Lee W, Park H, et al. Automatic Classification of Tremor Severity in Parkinson's Disease Using a Wearable Device. Sensors (Basel). 2017;17

[75] Fraiwan L, Khnouf R, Mashagbeh AR. Parkinson's disease hand tremor detection system for mobile application. J Med Eng Technol. 2016;40:127-34

[76] Thanawattano C, Pongthornseri R, Anan C, et al. Temporal fluctuations of tremor signals from inertial sensor: a preliminary study in differentiating Parkinson's disease from essential tremor. Biomed Eng Online. 2015;14:101

[77] Thanawattano C, Anan C, Pongthornseri R, et al. Temporal fluctuation analysis of tremor signal in Parkinson's disease and Essential tremor subjects. Conf Proc IEEE Eng Med Biol Soc. 2015;2015:6054-7

[78] Zeuner KE, Shoge RO, Goldstein SR, et al. Accelerometry to distinguish psychogenic from essential or parkinsonian tremor. Neurology. 2003;61:548-50

[79] Lin PC, Chen KH, Yang BS, et al. A digital assessment system for evaluating kinetic tremor in essential tremor and Parkinson's disease. BMC Neurol. 2018;18:25

[80] Balachandar A, Fasano A. Characterizing Orthostatic Tremor Using a Smartphone Application. Tremor Other Hyperkinet Mov (N Y). 2017;7:488

\section{*Application of technology-based objective measures to assess speech using technology- based objective measures.}


[81] Godino-Llorente JI, Shattuck-Hufnagel S, Choi JY, et al. Towards the identification of Idiopathic Parkinson's Disease from the speech. New articulatory kinetic biomarkers. PLoS One. $2017 \mathrm{Dec}$

[82] Bunton K. Patterns of lung volume use during an extemporaneous speech task in persons with Parkinson disease. J Commun Disord. 2005;38:331-48

[83] Fischer E, Goberman AM. Voice onset time in Parkinson disease. J Commun Disord. 2010;43:21-34

[84] Vaiciukynas E, Verikas A, Gelzinis A, et al. Detecting Parkinson's disease from sustained phonation and speech signals. PLoS One. 2017;12:e0185613

[85] Gauvin HS, Mertens J, Mariën P, et al. Verbal monitoring in Parkinson's disease: A comparison between internal and external monitoring. PLoS One. 2017;12:e0182159

[86] Rektorova I, Mekyska J, Janousova E, et al. Speech prosody impairment predicts cognitive decline in Parkinson's disease. Parkinsonism Relat Disord. 2016;29:90-5

[87] Arora S, Venkataraman V, Zhan A, et al. Detecting and monitoring the symptoms of Parkinson's disease using smartphones: A pilot study. Parkinsonism Relat Disord. 2015;21:650-3

\section{*Assessment of Parkinson's disease-associated sleep disorders using polysomnography and other technology-based objective measures.}

[88] Perez-Lloret S, Rossi M, Nouzeilles MI, et al. Parkinson's disease sleep scale, sleep logs, and actigraphy in the evaluation of sleep in parkinsonian patients. J Neurol. 2009;256:1480-4

[89] Norlinah MI, Afidah KN, Noradina AT, et al. Sleep disturbances in Malaysian patients with Parkinson's disease using polysomnography and PDSS. Parkinsonism Relat Disord. 2009; $15: 670-4$

[90] Loo HV, Tan EK. Case-control study of restless legs syndrome and quality of sleep in Parkinson's disease. J Neurol Sci. 2008;266:145-9 
[91] Shpirer I, Miniovitz A, Klein C, et al. Excessive daytime sleepiness in patients with Parkinson's disease: a polysomnography study. Mov Disord. 2006;21:1432-8

[92] Alatriste-Booth V, Rodríguez-Violante M, Camacho-Ordoñez A, et al. Prevalence and correlates of sleep disorders in Parkinson's disease: a polysomnographic study. Arq Neuropsiquiatr. 2015;73:241-5

[93] Diederich NJ, Vaillant M, Leischen M, et al. Sleep apnea syndrome in Parkinson's disease. A case-control study in 49 patients. Mov Disord. 2005;20:1413-38

[94] Gagnon JF, Bédard MA, Fantini ML, et al. REM sleep behavior disorder and REM sleep without atonia in Parkinson's disease. Neurology. 2002;59:585-9

[95] Gagnon JF, Fantini ML, Bédard MA, et al. Association between waking EEG slowing and REM sleepbehavior disorder in PD without dementia. Neurology. 2004;62:401-6.

[96] Valli K, Frauscher B, Peltomaa T et al. Dreaming furiously? A sleep laboratory study on the dream content of people with Parkinson's disease and with or without rapid eye movement sleep behavior disorder. Sleep Med. 2015;16:419-27

[97] Louter M, Arends JB, Bloem BR, et al. Actigraphy as a diagnostic aid for REM sleep behavior disorder in Parkinson's disease. BMC Neurol. 2014;14:76

[98] Comella CL, Tanner CM, Ristanovic RK. Polysomnographic sleep measures in Parkinson's disease patients with treatment-induced hallucinations. Ann Neurol. 1993;34:710-4

[99] Schroeder LA, Rufra O, Sauvageot N, et al. Reduced Rapid Eye Movement Density in Parkinson Disease: A Polysomnography-Based Case-Control Study. Sleep. 2016;39:213339. [100] Roth T, Rye DB, Borchert LD, et al. Assessment of sleepiness and unintended sleep in Parkinson's disease patients taking dopamine agonists. Sleep Med. 2003;4:275-80

[101] Möller JC, Stiasny K, Hargutt V, et al. Evaluation of sleep and driving performance in six patients with Parkinson's disease reporting sudden onset of sleep under dopaminergic medication: a pilot study. Mov Disord. 2002;17:474-81 
[102] Möller JC, Unger M, Stiasny-Kolster K et al. Continuous sleep EEG monitoring in PD patients with and without sleepattacks. Parkinsonism Relat Disord. 2009;15:238-41

[103] Dhawan V, Dhoat S, Williams AJ, et al. The range and nature of sleep dysfunction in untreated Parkinson's disease (PD). A comparative controlled clinical study using the Parkinson's disease sleep scale and selective polysomnography. J Neurol Sci. 2006;248:158-62

[104] Vaughan CP, Juncos JL, Trotti LM, et al. Nocturia and overnight polysomnography in Parkinson disease. Neurourol Urodyn. 2013;32:1080-5

[105] Diederich NJ, Paolini V, Vaillant M. Slow wave sleep and dopaminergic treatment in Parkinson's disease: a polysomnographic study. Acta Neurol Scand. 2009;120:308-13

[106] Zibetti M, Romagnolo A, Merola A, et al. A polysomnographic study in parkinsonian patients treated with intestinal levodopa infusion. J Neurol. 2017;264:1085-90

[107] Cicolin A, Lopiano L, Zibetti M, et al. Effects of deep brain stimulation of the subthalamic nucleus on sleep architecture in parkinsonian patients. Sleep Med. 2004;5:207-10

[108] Young A, Home M, Churchward T, et al. Comparison of sleep disturbance in mild versus severe Parkinson's disease. Sleep. 2002;25:573-7

[109] Uemura Y, Nomura T, Inoue Y, et al. Validation of the Parkinson's disease sleep scale in Japanese patients: a comparison study using the Pittsburgh Sleep Quality Index, the Epworth Sleepiness Scale and Polysomnography. J Neurol Sci. 2009;287:36-40

\section{*Assessment of Parkinson's disease-associated cognitive symptoms using electroencephalography and evoked potentials.}

[110] Tanaka H, Koenig T, Pascual-Marqui RD, et al. Event-related potential and EEG measures in Parkinson's disease without and with dementia. Dement Geriatr Cogn Disord. 2000;11:39-45

[111] Fonseca LC, Tedrus GM, Letro GH, et al. Dementia, mild cognitive impairment and quantitative EEG in patients with Parkinson's disease. Clin EEG Neurosci. 2009;40:168-72 
[112] Zimmermann R, Gschwandtner U, Hatz F, et al. Correlation of EEG slowing with cognitive domains in nondemented patients with Parkinson's disease. Dement Geriatr Cogn Disord. 2015;39:207-14

[113] Latreille V, Carrier J, Lafortune M, et al. Sleep spindles in Parkinson's disease may predict the development of dementia. Neurobiol Aging. 2015;36:1083-90

[114] Markser A, Maier F, Lewis CJ, et al. Deep brain stimulation and cognitive decline in Parkinson's disease: The predictive value of electroencephalography. J Neurol. 2015;262:227584

[115] Latreille V, Carrier J, Gaudet-Fex B, et al. Electroencephalographic prodromal markers of dementia across conscious states in Parkinson's disease. Brain. 2016;139:1189-99

[116] Matsui H, Nishinaka K, Oda M, et al. Auditory event-related potentials in Parkinson's disease: prominent correlation with attention. Parkinsonism Relat Disord. 2007;13:394-8

[117] Katsarou Z, Bostantjopoulou S, Kimiskidis V, et al. Auditory event-related potentials in Parkinson's disease in relation to cognitive ability. Percept Mot Skills. 2004;98:1441-8

[118] Bodis-Wollner I, Borod JC, Cicero B, et al. Modality dependent changes in event-related potentials correlate with specific cognitive functions in nondemented patients with Parkinson's disease. J Neural Transm Park Dis Dement Sect. 1995;9:197-209

[119] Hawkes CH, Shephard BC, Daniel SE. Olfactory dysfunction in Parkinson's disease. J Neurol Neurosurg Psychiatry. 1997;62:436-46

[120] Peppe A, Stanzione P, Pierelli F, et al. Visual alterations in de novo Parkinson's disease: pattern electroretinogram latencies are more delayed and more reversible by levodopa than are visual evoked potentials. Neurology. 1995;45:1144-8

[121] Pekkonen E, Jousmäki V, Reinikainen K, et al. Automatic auditory discrimination is impaired in Parkinson's disease. Electroencephalogr Clin Neurophysiol. 1995;95:47-52 
[122] Green J, Woodard JL, Sirockman BE, et al. Event-related potential P3 change in mild Parkinson's disease. Mov Disord. 1996;11:32-42

[123] Okuda B, Tachibana H, Kawabata K, et al. Visual evoked potentials (VEPs) in Parkinson's disease: correlation of pattern VEPs abnormality with dementia. Alzheimer Dis Assoc Disord. 1995 Summer;9:68-72

[124] Vieregge P, Verleger R, Wascher E, et al. Auditory selective attention is impaired in Parkinson's disease--event-related evidence from EEG potentials. Brain Res Cogn Brain Res. $1994 ; 2: 117-29$

[125] Nojszewska M, Pilczuk B, Zakrzewska-Pniewska B, et al. The auditory system involvement in Parkinson disease: electrophysiological and neuropsychological correlations. $\mathrm{J}$ Clin Neurophysiol. 2009;26:430-7

[126] Kim GW, Sohn YH, Huh K, et al. Relationship between the auditory P300 and the procedural memory function in drug-naive patients with Parkinson's disease. Yonsei Med J. $1995 ; 36: 367-71$

[127] Sagliocco L, Bandini F, Pierantozzi M, et al. Electrophysiological evidence for visuocognitive dysfunction in younger non Caucasian patients with Parkinson's disease. J Neural Transm (Vienna). 1997;104(4-5):427-39

[128] Antal A, Dibó G, Kéri S, et al. P300 component of visual event-related potentials distinguishes patients with idiopathic parkinson's disease from patients with essential tremor. $\mathrm{J}$ Neural Transm (Vienna). 2000;107:787-97

[129] Büttner T, Kuhn W, Müller T, et al. Chromatic and achromatic visual evoked potentials in Parkinson's disease. Electroencephalogr Clin Neurophysiol. 1996;100:443-7

[130] Filipović SR, Sternić N, Svetel M, et al. Bereitschaftspotential in depressed and nondepressed patients with Parkinson's disease. Mov Disord. 200;16:294-300

\section{*Assessment of Parkinson's disease-associated autonomic dysfunction using technology- based objective measures.}


[131] Low PA, Tomalia VA, Park KJ. Autonomic function tests: some clinical applications. J Clin Neurol. 2013;9:1-8

[132] Oka H, Mochio S, Yoshioka M, et al. Evaluation of baroreflex sensitivity by the sequence method using blood pressure oscillations and R-R interval changes during deep respiration. Eur Neurol. 2003;50:230-43

[133] Oka H, Mochio S, Sato H, et al. Prolongation of QTc interval in patients with Parkinson's disease. Eur Neurol. 1997;37:186-9

[134] Mastrocola C, Vanacore N, Giovani A et al. Twenty-four-hour heart rate variability to assess autonomic function in Parkinson's disease. Acta Neurol Scand. 1999;99:245-7

[135] Haapaniemi TH, Pursiainen V, Korpelainen JT, et al. Ambulatory ECG and analysis of heart rate variability in Parkinson's disease. J Neurol Neurosurg Psychiatry. 2001;70:305-10

[136] Tanaka R, Shimo Y, Yamashiro K, et al. Association between abnormal nocturnal blood pressure profile and dementia in Parkinson's disease. Parkinsonism Relat Disord. 2018;46:24-9

[137] Pavy-LeTraon A, Brefel-Courbon C, Dupouy J, et al. Combined cardiovascular and sweating autonomic testing to differentiate multiple system atrophy from Parkinson's disease. Neurophysiol Clin. 2018;48:103-10

[138] Baschieri F, Calandra-Buonaura G, Doria A, et al. Cardiovascular autonomic testing performed with a new integrated instrumental approach is useful in differentiating MSA-P from PD at an early stage. Parkinsonism Relat Disord. 2015;21:477-82

[139] De Pablo-Fernandez E, Tur C, Revesz T, et al. Association of Autonomic Dysfunction With Disease Progression and Survival in Parkinson Disease. JAMA Neurol. 2017;74:970-6 [140] Merola A, Romagnolo A, Comi C et al. Prevalence and burden of dysautonomia inadvanced Parkinson's disease. Mov Disord. 2017;32:796-7 
[141] Artusi CA, Mishra M, Latimer P, et al. Integration of technology-based outcome measures in clinical trials of Parkinson and other neurodegenerative diseases. Parkinsonism Relat Disord. 2018;46:S53-S56

[142] Onorati F, Regalia G, Caborni C, et al. Multicenter clinical assessment of improved wearable multimodal convulsive seizure detectors. Epilepsia. 2017;58:1870-9

[143] Ryvlin P, Ciumas C, Wisniewski I, et al. Wearable devices for sudden unexpected death in epilepsy prevention. Epilepsia. 2018;59 Suppl 1:61-6

[144] Ellis T, Cavanaugh JT, Earhart GM, et al. Which measures of physical function and motor impairment best predict quality of life in Parkinson's disease? Parkinsonism Relat Disord. 2011;17:693-7

[145] Sánchez-Ortuño MM, Edinger JD, Means MK, et al. Home is where sleep is: an ecological approach to test the validity of actigraphy for the assessment of insomnia. J Clin Sleep Med. 2010;:21-9

[146] Milazzo V, Di Stefano C, Vallelonga F, et al. Reverse blood pressure dipping as marker of dysautonomia in Parkinson disease. Park Rel Disord. 2018 - In Press

[147] Merola A, Sawyer RP, Artusi CA, et al. Orthostatic hypotension in Parkinson disease: Impact on health care utilization. Parkinsonism Relat Disord. 2018;47:45-9

[148] Merola A, Romagnolo A, Rosso M, et al. Orthostatic hypotension in Parkinson's disease: Does it matter if asymptomatic? Parkinsonism Relat Disord. 2016 Dec;33:65-71

[149] Espay AJ, Bonato P, Nahab FB, et al.; Movement Disorders Society Task Force on Technology. Technology in Parkinson's disease: Challenges and opportunities. Mov Disord. 2016;31:1272-82 


\section{FIGURES TITLES AND LEGENDS}

\section{Figure 1. Study selection algorithm}

Out of 2941 records initially identified from our searching strategy, we screened 145 articles that were evaluated for eligibility, which eventually led to the inclusion of 124 studies that underwent data extraction and analysis.

\section{Figure 2. Technology employed in the assessment of motor and non-motor phenomena in Parkinson disease}

A wide range of technologies has been employed in the assessment of motor and non-motor phenomena of Parkinson disease. In the figure are reported systems/devices used along with the number of associated studies.

\section{Figure 3. Number of studies employing technology-based objective measures in the} assessment of motor and non-motor phenomena in Parkinson disease An increasing number of studies have employed technology-based objective measures for the assessment of motor and non-motor phenomena associated with Parkinson disease over the last three decades.

\section{Figure 4. Kinematic and Posture Analysis}

A: Infrared camera, computerized walkway for gait analysis, and wearable sensors worn of each extremity and on the chest can be used to sensitively capture aspects related to patient's mobility in the three axes of space, including neck, arm, and hip movements.

B: Force plate and wearable sensors can be used to estimate postural stability, which can be represented as a line indicating the postural sway of the center of mass over a 30 -second period of time. Irregular and wide oscillations of the center of mass are indicative of postural instability.

\section{Figure 5. Telehealth application for wearable technologies}

Wearables have the potential to capture multiple motor and non-motor phenomena associated with Parkinson disease and transmit data using wireless Internet and Bluetooth connections. 
2941 Records identified through database searching and reference lists relevant removed

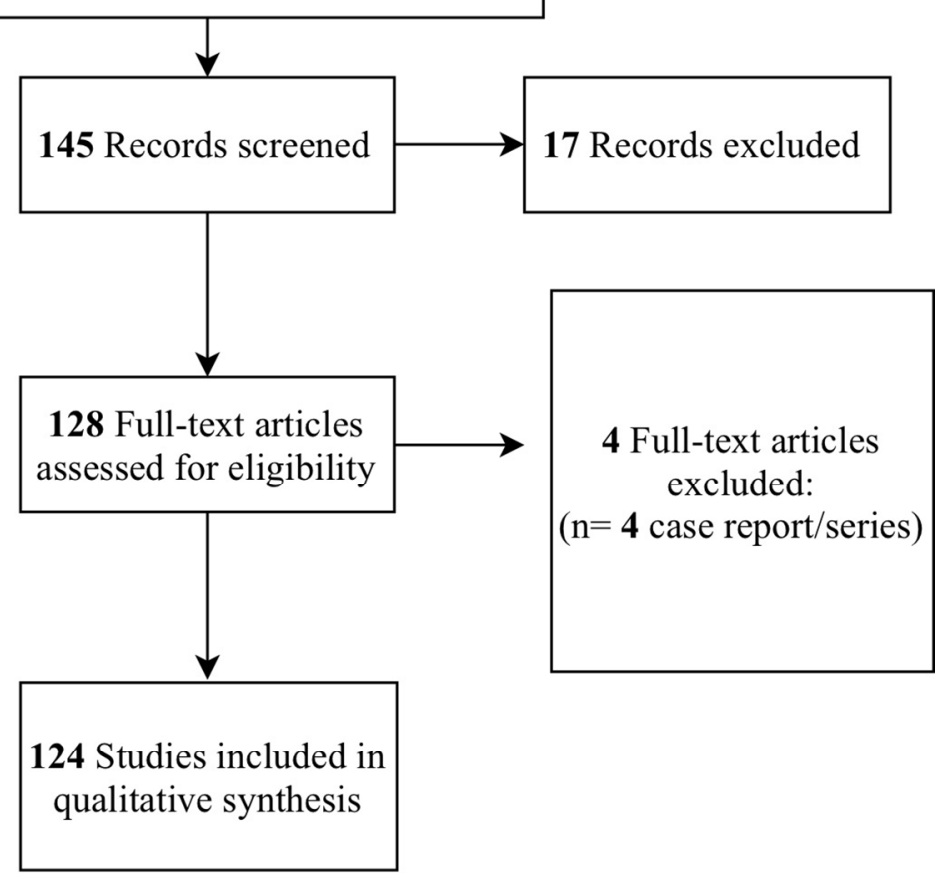

Study selection algorithm.

Out of 2941 records initially identified from our searching strategy, we screened 145 articles that were evaluated for eligibility, which eventually led to the inclusion of 124 studies that underwent data extraction and analysis.

$122 \times 124 \mathrm{~mm}(300 \times 300 \mathrm{DPI})$ 
Technology employed in the assessment of motor and non-motor phenomena in Parkinson disease. A wide range of technologies has been employed in the assessment of motor and non-motor phenomena of Parkinson disease. In the figure are reported systems/devices used along with the number of associated studies.

$125 \times 124 \mathrm{~mm}(300 \times 300$ DPI $)$

\section{Non motor}

Polysomnography $=20$

Electroencphalography $=14$

Evoked Potentials $=7$

Speech analysis $=7$

Electrocardiogram $=5$

Autonomic testing $=6$

Actigraphy $=3$

\section{Electromiography $=1$}

Accelerometer $/$ Gyroscope $=1$

\section{Dynamometer $=1$}




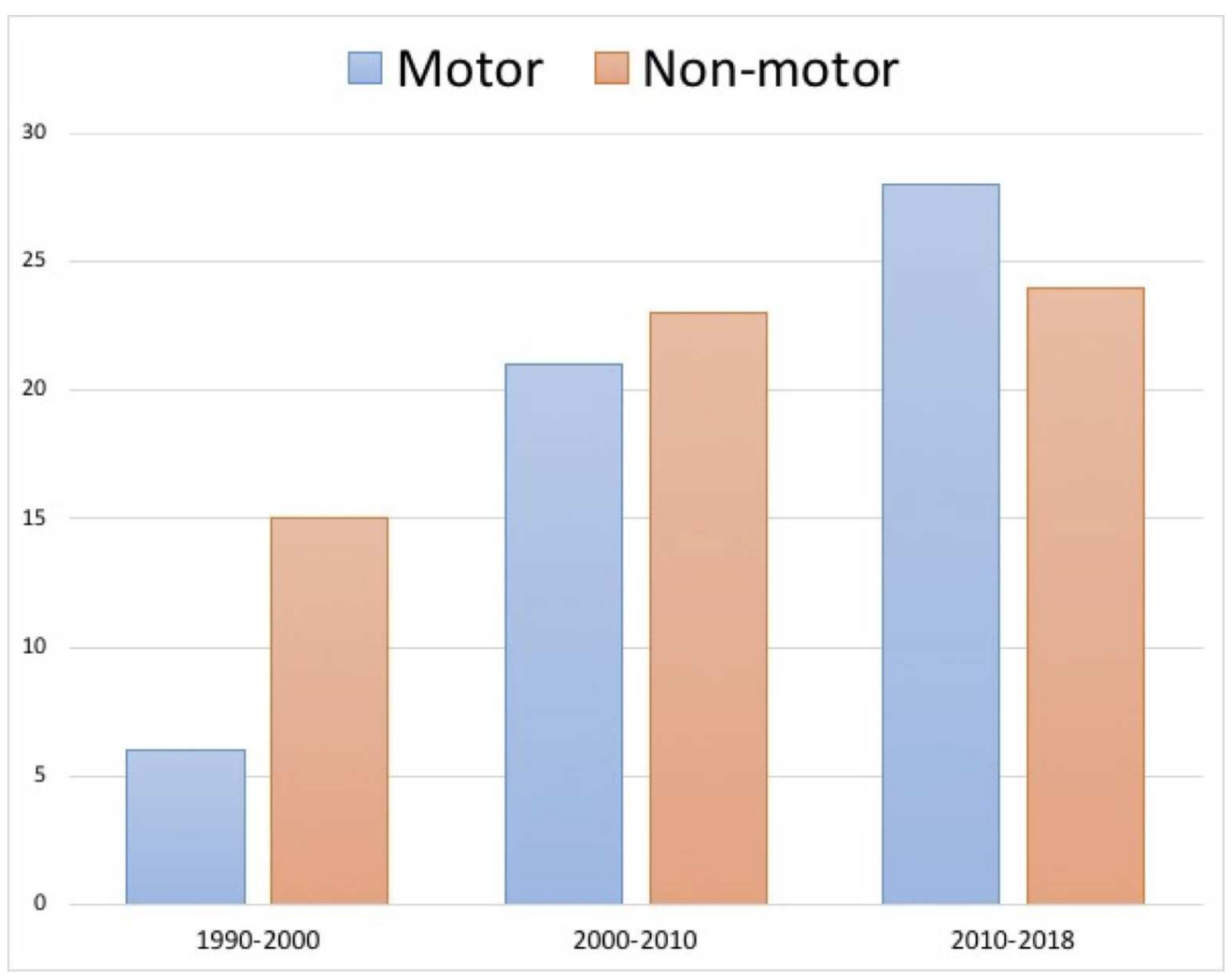

Number of studies employing technology-based objective measures in the assessment of motor and nonmotor phenomena in Parkinson disease.

An increasing number of studies have employed technology-based objective measures for the assessment of motor and non-motor phenomena associated with Parkinson disease over the last three decades.

$$
210 \times 165 \mathrm{~mm}(300 \times 300 \mathrm{DPI})
$$




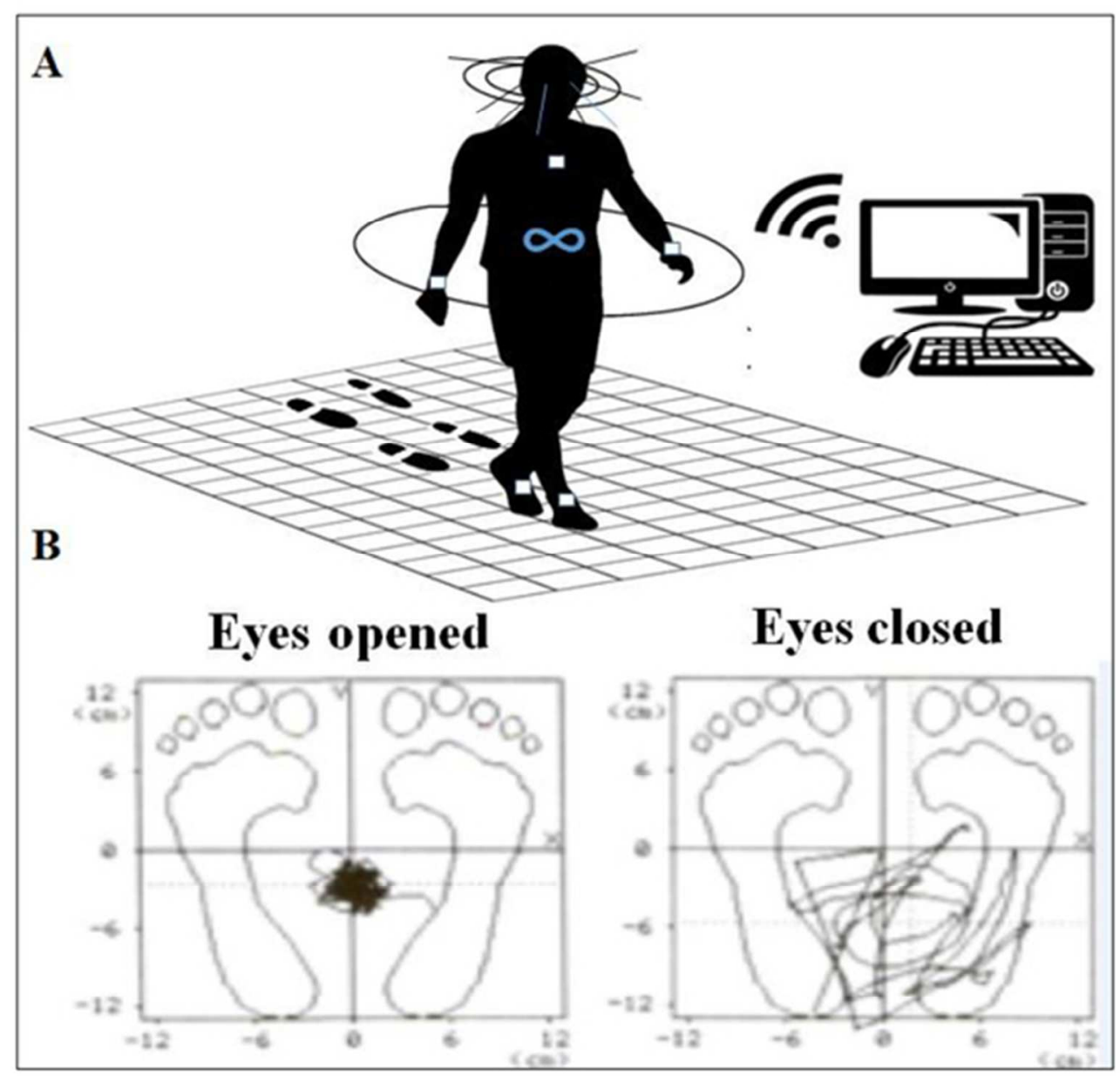

Kinematic and Posture Analysis.

A: Infrared camera, computerized walkway for gait analysis, and wearable sensors worn of each extremity and on the chest can be used to sensitively capture aspects related to patient's mobility in the three axes of space, including neck, arm, and hip movements.

B: Force plate and wearable sensors can be used to estimate postural stability, which can be represented as a line indicating the postural sway of the center of mass over a 30-second period of time. Irregular and wide oscillations of the center of mass are indicative of postural instability.

$49 \times 48 \mathrm{~mm}(300 \times 300$ DPI $)$ 
Telehealth application for wearable technologies.

Wearables have the potential to capture multiple motor and non-motor phenomena associated with Parkinson disease and transmit data using wireless Internet and Bluetooth connections.

$46 \times 24 \mathrm{~mm}(300 \times 300 \mathrm{DPI})$ 
1

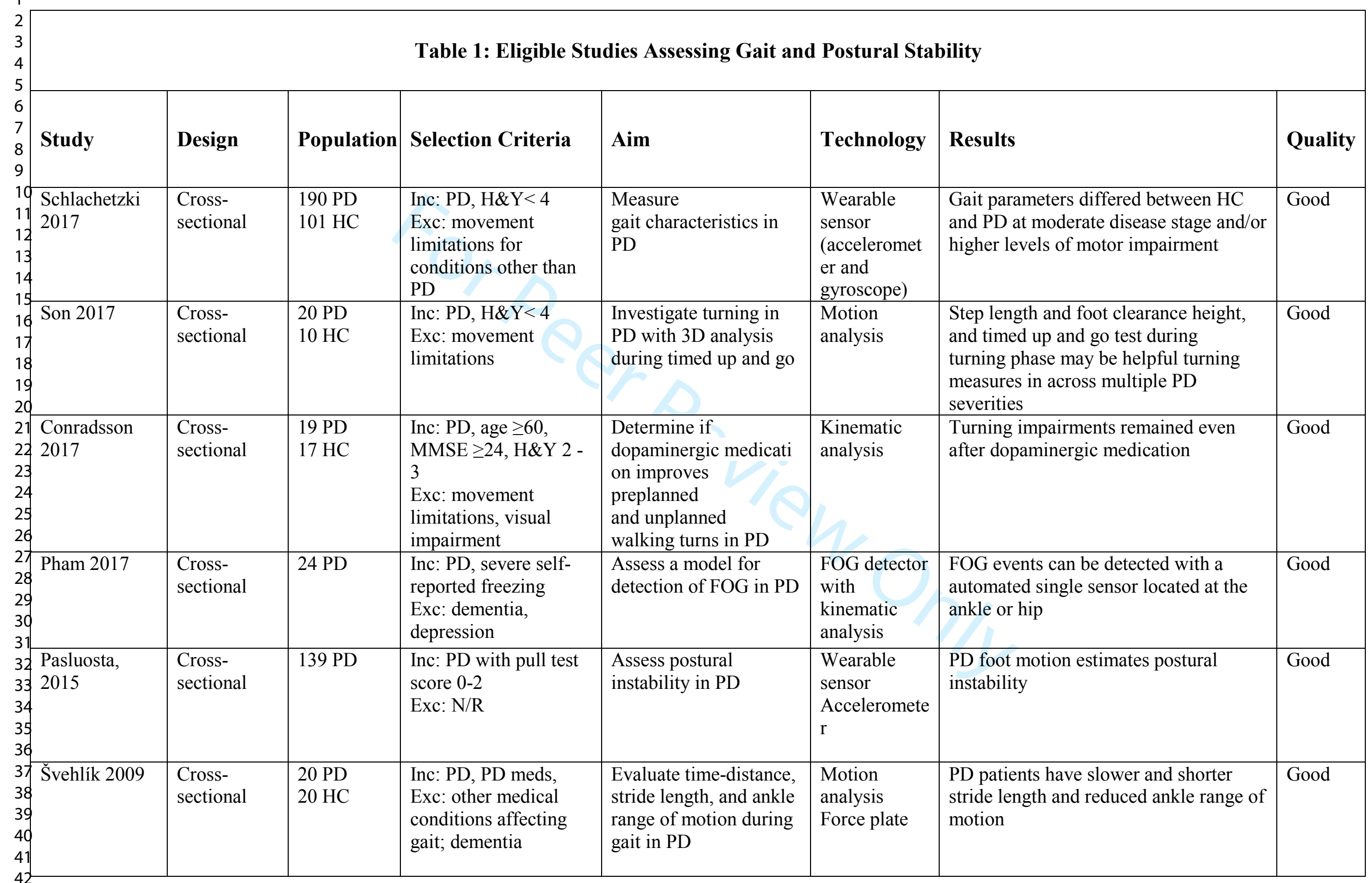




\begin{tabular}{|c|c|c|c|c|c|c|c|c|}
\hline $\begin{array}{l}2 \\
3 \\
4 \\
5\end{array}$ & Kim 2009 & $\begin{array}{l}\text { Cross- } \\
\text { sectional }\end{array}$ & $\begin{array}{l}7 \mathrm{PD} \\
14 \mathrm{HC}\end{array}$ & $\begin{array}{l}\text { Inc: PD } \\
\text { Exc: } N / R\end{array}$ & $\begin{array}{l}\text { Evaluate postural } \\
\text { responses of patients } \\
\text { with PD during } \\
\text { perturbation }\end{array}$ & $\begin{array}{l}\text { Force plate } \\
\text { Kinematic } \\
\text { analysis }\end{array}$ & $\begin{array}{l}\text { PD showed worse ankle feedback gain } \\
\text { during perturbation }\end{array}$ & Good \\
\hline $\begin{array}{l}6 \\
7 \\
8 \\
9 \\
10\end{array}$ & Cho 2009 & $\begin{array}{l}\text { Cross- } \\
\text { sectional }\end{array}$ & $\begin{array}{l}10 \mathrm{PD} \\
7 \mathrm{HC}\end{array}$ & $\begin{array}{l}\text { Inc: PD } \\
\text { Exc: } N / R\end{array}$ & $\begin{array}{l}\text { Examine walking } \\
\text { dynamics in PD }\end{array}$ & $\begin{array}{l}\text { Motion } \\
\text { analysis }\end{array}$ & $\begin{array}{l}\text { PD has greater gait impairment with } \\
\text { decreased foot control and arm swing } \\
\text { dynamics }\end{array}$ & Good \\
\hline $\begin{array}{l}11 \\
12 \\
13 \\
14\end{array}$ & McVey 2009 & $\begin{array}{l}\text { Cross- } \\
\text { sectional }\end{array}$ & $\begin{array}{l}10 \mathrm{PD} \\
10 \mathrm{HC}\end{array}$ & $\begin{array}{l}\text { Inc: PD } \\
\text { Exc: } N / R\end{array}$ & $\begin{array}{l}\text { Estimate postural } \\
\text { instability in } \mathrm{PD}\end{array}$ & $\begin{array}{l}\text { Force plate } \\
\text { Kinematic } \\
\text { analysis }\end{array}$ & $\begin{array}{l}\text { Early PD has greater postural instability } \\
\text { vs. HC }\end{array}$ & Good \\
\hline $\begin{array}{l}10 \\
16 \\
11 \\
18 \\
19\end{array}$ & Alice 2007 & $\begin{array}{l}\text { Cross- } \\
\text { sectional }\end{array}$ & $10 \mathrm{PD}$ & $\begin{array}{l}\text { Inc: PD, history of FOG } \\
\text { Exc: medical conditions } \\
\text { affecting gait other than } \\
\text { PD }\end{array}$ & $\begin{array}{l}\text { Describe strides } \\
\text { characteristics prior to } \\
\text { freezing vs. voluntary } \\
\text { and ongoing gait }\end{array}$ & $\begin{array}{l}\text { Kinematic } \\
\text { analysis }\end{array}$ & $\begin{array}{l}\text { PD had decrease in ankle and hip joint } \\
\text { range of motion prior to freezing, with } \\
\text { preserved movement shape }\end{array}$ & Good \\
\hline $\begin{array}{l}20 \\
21 \\
22 \\
23\end{array}$ & Hong 2007 & $\begin{array}{l}\text { Cross- } \\
\text { sectional }\end{array}$ & $\begin{array}{l}12 \mathrm{PD} \\
16 \mathrm{HC}\end{array}$ & $\begin{array}{l}\text { Inc: } P D, \text { mild turning } \\
\text { problems } \\
\text { Exc: } N / R\end{array}$ & $\begin{array}{l}\text { Determine if PD retain } \\
\text { turning ability after } \\
\text { rotating platform } \\
\text { walking }\end{array}$ & $\begin{array}{l}\text { Kinematic } \\
\text { analysis }\end{array}$ & $\begin{array}{l}\text { PD retained turning ability after rotating } \\
\text { platform walking task }\end{array}$ & Good \\
\hline $\begin{array}{l}24 \\
25 \\
26 \\
27 \\
28 \\
29 \\
30 \\
31 \\
32\end{array}$ & Ferrarin 2005 & $\begin{array}{l}\text { Cross- } \\
\text { sectional }\end{array}$ & $10 \mathrm{PD}$ & $\begin{array}{l}\text { Inc: PD, bilateral STN } \\
\text { DBS, severe motor } \\
\text { fluctuations, response } \\
\text { to L-dopa } \\
\text { Exc: dementia, } \\
\text { depression, abnormal } \\
\text { cerebral MRI, other } \\
\text { illnesses }\end{array}$ & $\begin{array}{l}\text { Assess the effects of L- } \\
\text { dopa and STN DBS } \\
\text { separately and } \\
\text { combined on gait in PD }\end{array}$ & $\begin{array}{l}\text { Kinematic } \\
\text { analysis }\end{array}$ & $\begin{array}{l}\text { PD meds and bilateral STN DBS } \\
\text { additively and synergistically improve } \\
\text { gait parameters such as speed, stride } \\
\text { length, and ROM of knee and ankle } \\
\text { joints }\end{array}$ & Good \\
\hline $\begin{array}{l}33 \\
34 \\
35 \\
36\end{array}$ & Stolze 2001 & $\begin{array}{l}\text { Cross- } \\
\text { sectional }\end{array}$ & $\begin{array}{l}9 \mathrm{PD} \\
10 \mathrm{HC}\end{array}$ & $\begin{array}{l}\text { Inc: Bilateral STN } \\
\text { stimulation } \\
\text { Exc: N/R }\end{array}$ & $\begin{array}{l}\text { Examine the impact of } \\
\text { STN-DBS on gait in } \\
\text { PD }\end{array}$ & $\begin{array}{l}\text { Kinematic } \\
\text { analysis }\end{array}$ & $\begin{array}{l}\text { STN-DBS increases gait velocity and } \\
\text { stride length }\end{array}$ & Good \\
\hline $\begin{array}{l}37 \\
38 \\
39 \\
40 \\
41\end{array}$ & Parisi 2015 & $\begin{array}{l}\text { Cross- } \\
\text { sectional }\end{array}$ & $34 \mathrm{PD}$ & $\begin{array}{l}\text { Inc: } N / R \\
\text { Exc: } N / R\end{array}$ & $\begin{array}{l}\text { Correlate wearable } \\
\text { sensor data with } \\
\text { UPDRS }\end{array}$ & $\begin{array}{l}\text { Wearable } \\
\text { sensor }\end{array}$ & $\begin{array}{l}\text { Wearable sensor accurately predicted } \\
\text { UPDRS scores }\end{array}$ & Fair \\
\hline
\end{tabular}


1

\begin{tabular}{|c|c|c|c|c|c|c|c|c|}
\hline $\begin{array}{l}5 \\
6 \\
7\end{array}$ & Chomiak 2015 & Case-control & $\begin{array}{l}24 \mathrm{PD} \\
\text { w\&w/o } \\
\text { freezing }\end{array}$ & $\begin{array}{l}\text { Inc: PD, walking } \\
\text { unassisted } \\
\text { Exc: dementia, diseases } \\
\text { that affect gait }\end{array}$ & $\begin{array}{l}\text { Evaluate if stepping-in- } \\
\text { place with a concurrent } \\
\text { mental task can be used } \\
\text { for evaluating } \\
\text { cognitive-motor } \\
\text { deficits in PD }\end{array}$ & $\begin{array}{l}\text { Kinematic } \\
\text { analysis }\end{array}$ & $\begin{array}{l}\text { Step height was significantly worse in } \\
\text { PD during concurrent subtraction and } \\
\text { stepping-in-place tasking }\end{array}$ & Fair \\
\hline $\begin{array}{l}8 \\
9 \\
10 \\
11 \\
12 \\
13\end{array}$ & $\begin{array}{l}\text { Dillmann } \\
2014\end{array}$ & $\begin{array}{l}\text { Cross- } \\
\text { sectional }\end{array}$ & $\begin{array}{l}40 \mathrm{PD} \\
25 \mathrm{HC}\end{array}$ & $\begin{array}{l}\text { Inc: akinetic-rigid PD } \\
\text { Exc: resting or postural } \\
\text { tremor }\end{array}$ & $\begin{array}{l}\text { Analyze movements of } \\
\text { the upper and lower } \\
\text { limbs in PD }\end{array}$ & $\begin{array}{l}\text { Kinematic } \\
\text { analysis } \\
\text { Treadmill- } \\
\text { based } \\
\text { assessment }\end{array}$ & $\begin{array}{l}\text { PD demonstrated greater intersegmental } \\
\text { coordination }\end{array}$ & Fair \\
\hline $\begin{array}{l}14 \\
15 \\
16 \\
11 \\
18 \\
19\end{array}$ & Barbe 2014 & Case-control & $\begin{array}{l}34 \mathrm{PD} \\
\mathrm{w} \& \mathrm{w} / \mathrm{o} \\
\text { freezing }\end{array}$ & $\begin{array}{l}\text { Inc: PD, akinetic-rigid, } \\
\text { right handed, age } 40- \\
80 \\
\text { Exc: depression, } \\
\text { dementia, movement } \\
\text { limitations }\end{array}$ & $\begin{array}{l}\text { Assess spatial and } \\
\text { temporal gait } \\
\text { variability between } \\
\text { FOG episodes in } \\
\text { freezers vs. non- } \\
\text { freezers }\end{array}$ & $\begin{array}{l}\text { Kinematic } \\
\text { analysis }\end{array}$ & $\begin{array}{l}\text { Freezers have a higher spatial gait } \\
\text { variability between freezing episodes }\end{array}$ & Fair \\
\hline $\begin{array}{l}20 \\
21 \\
22 \\
23 \\
24\end{array}$ & Moore 2013 & $\begin{array}{l}\text { Cross- } \\
\text { sectional }\end{array}$ & $25 \mathrm{PD}$ & $\begin{array}{l}\text { Inc: PD, self-reported } \\
\text { freezing, MMSE } \geq 24 \\
\text { Exc: dementia, major } \\
\text { depression }\end{array}$ & $\begin{array}{l}\text { Evaluate sensor } \\
\text { placement for accuracy } \\
\text { in detecting FOG in PD }\end{array}$ & $\begin{array}{l}\text { Kinematic } \\
\text { analysis } \\
\text { Acceleromete } \\
\mathrm{r}\end{array}$ & $\begin{array}{l}\text { A simpler single lumbar sensor had } \\
\text { comparable accuracy to a } 7 \text { sensor } \\
\text { system for detecting FOG }\end{array}$ & Fair \\
\hline $\begin{array}{l}24 \\
25 \\
26 \\
27 \\
28 \\
29 \\
30\end{array}$ & Zampieri 2011 & $\begin{array}{l}\text { Cross- } \\
\text { sectional }\end{array}$ & $\begin{array}{l}6 \mathrm{PD} \\
8 \mathrm{HC}\end{array}$ & $\begin{array}{l}\text { Inc: } \mathrm{N} / \mathrm{R} \\
\text { Exc: no space in home } \\
\text { to walk 5-7 meters }\end{array}$ & $\begin{array}{l}\text { Evaluate stride length, } \\
\text { stride velocity, } \\
\text { cadence, peak arm } \\
\text { swing velocity, and } \\
\text { turning velocity during } \\
\text { Timed Up and Go }\end{array}$ & $\begin{array}{l}\text { Wearable } \\
\text { sensor }\end{array}$ & $\begin{array}{l}\text { PD exhibited faster gait in laboratory } \\
\text { than at home, although with shorter gait } \\
\text { and steps in both conditions vs. HC }\end{array}$ & Fair \\
\hline $\begin{array}{l}31 \\
32 \\
33 \\
34\end{array}$ & Merello 2010 & $\begin{array}{l}\text { Cross- } \\
\text { sectional }\end{array}$ & $\begin{array}{l}20 \mathrm{PD} \\
17 \mathrm{HC}\end{array}$ & $\begin{array}{l}\text { Inc: PD } \\
\text { Normal MRI } \\
\text { H\&Y in OFF }=3 \\
\text { Exc: dementia }\end{array}$ & $\begin{array}{l}\text { Evaluate COM, COP, } \\
\text { step length, and speed } \\
\text { changes during } \\
\text { festination in PD }\end{array}$ & $\begin{array}{l}\text { Kinematic } \\
\text { analysis }\end{array}$ & $\begin{array}{l}\text { Patients with festination attempt to align } \\
\text { COP to COM }\end{array}$ & Fair \\
\hline $\begin{array}{l}35 \\
36 \\
37 \\
38 \\
39 \\
40\end{array}$ & Salarian 2010 & $\begin{array}{l}\text { Cross- } \\
\text { sectional }\end{array}$ & $\begin{array}{l}12 \mathrm{PD} \\
12 \mathrm{HC}\end{array}$ & $\begin{array}{l}\text { Inc: H\&Y } 1 \text { to } 2.5 \text {, no } \\
\text { history of PD drugs } \\
\text { Exc: other neurological } \\
\text { disorders, orthopedic } \\
\text { disorders/devices }\end{array}$ & $\begin{array}{l}\text { Evaluate cadence, } \\
\text { turning duration, and } \\
\text { arm-swing angular } \\
\text { velocity during Time } \\
\text { Up and Go }\end{array}$ & $\begin{array}{l}\text { Wearable } \\
\text { sensor }\end{array}$ & $\begin{array}{l}\text { PD demonstrated slower cadence and } \\
\text { arm swing angular velocity and longer } \\
\text { turning time duration }\end{array}$ & Fair \\
\hline
\end{tabular}




\begin{tabular}{|c|c|c|c|c|c|c|c|c|}
\hline $\begin{array}{l}2 \\
3 \\
4 \\
5 \\
6 \\
7 \\
8\end{array}$ & Ganesan 2010 & $\begin{array}{l}\text { Cross- } \\
\text { sectional }\end{array}$ & $\begin{array}{l}20 \mathrm{PD} \\
20 \mathrm{HC}\end{array}$ & $\begin{array}{l}\text { Inc: } H \& Y=2 \text {, stable } \\
\text { PD meds, normal pull } \\
\text { test, right dominance } \\
\text { Exc: cognitive deficits, } \\
\text { depression, motor } \\
\text { fluctuations, orthopedic } \\
\text { problems }\end{array}$ & $\begin{array}{l}\text { Evaluate subclinical } \\
\text { balance impairment in } \\
\text { PD with normal pull } \\
\text { test }\end{array}$ & Force plate & $\begin{array}{l}\text { PD patients had subclinical direction- } \\
\text { specific balance impairment }\end{array}$ & Fair \\
\hline $\begin{array}{l}9 \\
10 \\
11 \\
12 \\
13\end{array}$ & Johnsen 2010 & $\begin{array}{l}\text { Cross- } \\
\text { sectional }\end{array}$ & $22 \mathrm{PD}$ & $\begin{array}{l}\text { Inc: PD, STN DBS } \\
\text { Exc: inability to walk }\end{array}$ & $\begin{array}{l}\text { Evaluate the effect of } \\
\text { anatomical position of } \\
\text { STN DBS on gait in PD }\end{array}$ & $\begin{array}{l}\text { Kinematic } \\
\text { analysis }\end{array}$ & $\begin{array}{l}\text { Step velocity, step length, and balance } \\
\text { had greater improvement with dorsal } \\
\text { STN DBS compared to ventral STN } \\
\text { DBS in PD. }\end{array}$ & Fair \\
\hline $\begin{array}{l}14 \\
15 \\
16 \\
11\end{array}$ & $\begin{array}{l}\text { Cantiniaux } \\
2010\end{array}$ & $\begin{array}{l}\text { Cross- } \\
\text { sectional }\end{array}$ & $\begin{array}{l}11 \mathrm{PD} \\
11 \mathrm{HC}\end{array}$ & $\begin{array}{l}\text { Inc: PD, bilateral STN } \\
\text { DBS } \\
\text { Exc: other walking or } \\
\text { speech disorders }\end{array}$ & $\begin{array}{l}\text { Assess the effects of L- } \\
\text { dopa and STN DBS on } \\
\text { gait and speech patterns } \\
\text { in PD vs. HC }\end{array}$ & $\begin{array}{l}\text { Kinematic } \\
\text { analysis } \\
\text { Speech } \\
\text { analysis }\end{array}$ & $\begin{array}{l}\text { Walking and speech velocity were } \\
\text { correlated, but STN DBS and L-dopa } \\
\text { improved walking velocity while } \\
\text { having no effect on speech velocity }\end{array}$ & Fair \\
\hline $\begin{array}{l}18 \\
19 \\
20 \\
21 \\
22 \\
23\end{array}$ & Mancini 2009 & $\begin{array}{l}\text { Cross- } \\
\text { sectional }\end{array}$ & $\begin{array}{l}11 \mathrm{PD} \\
12 \mathrm{HC}\end{array}$ & $\begin{array}{l}\text { Inc: PD, no history of } \\
\text { PD meds } \\
\text { Exc: other neurologic } \\
\text { disorders or gait } \\
\text { impairments }\end{array}$ & $\begin{array}{l}\text { Evaluate anticipatory } \\
\text { postural adjustments } \\
\text { and characterize step } \\
\text { initiation deficits in PD }\end{array}$ & $\begin{array}{l}\text { Force plate } \\
\text { Acceleromete } \\
\mathrm{r}\end{array}$ & $\begin{array}{l}\text { Untreated PD exhibited smaller peak } \\
\text { trunk acceleration vs. HC }\end{array}$ & Fair \\
\hline 24 & Hong 2009 & $\begin{array}{l}\text { Cross- } \\
\text { sectional }\end{array}$ & $\begin{array}{l}11 \mathrm{PD} \\
12 \mathrm{HC}\end{array}$ & $\begin{array}{l}\text { Inc: PD } \\
\text { Exc: } N / R\end{array}$ & $\begin{array}{l}\text { Determine objective } \\
\text { differences in turning in } \\
\text { PD vs. HC during a } \\
\text { turning task }\end{array}$ & $\begin{array}{l}\text { Kinematic } \\
\text { analysis } \\
\text { EMG }\end{array}$ & $\begin{array}{l}\text { PD differed from } \mathrm{HC} \text { in axial control } \\
\text { but had similar lower limb muscle } \\
\text { patterns during turning task }\end{array}$ & Fair \\
\hline $\begin{array}{l}28 \\
29 \\
30 \\
31 \\
32\end{array}$ & Stack 2008 & $\begin{array}{l}\text { Cross- } \\
\text { sectional }\end{array}$ & $\begin{array}{l}28 \mathrm{PD} \\
12 \mathrm{HC}\end{array}$ & $\begin{array}{l}\text { Inc: PD, walk w/o } \\
\text { assistance } \\
\text { Exc: Neurological } \\
\text { comorbidities }\end{array}$ & $\begin{array}{l}\text { Analyze differences in } \\
\text { turning in PD vs. HC } \\
\text { during a turning task }\end{array}$ & $\begin{array}{l}\text { Motion } \\
\text { analysis }\end{array}$ & $\begin{array}{l}\text { PD differed on step count, time, and } \\
\text { quality of turn versus HC }\end{array}$ & Fair \\
\hline $\begin{array}{l}33 \\
34 \\
35 \\
36\end{array}$ & Huxham 2008 & $\begin{array}{l}\text { Cross- } \\
\text { sectional }\end{array}$ & $\begin{array}{l}10 \mathrm{PD} \\
10 \mathrm{HC}\end{array}$ & $\begin{array}{l}\text { Inc: PD } \\
\text { Exc: N/R }\end{array}$ & $\begin{array}{l}\text { Analyze head and trunk } \\
\text { rotation of PD vs. HC } \\
\text { during walking turns }\end{array}$ & $\begin{array}{l}\text { Kinematic } \\
\text { analysis }\end{array}$ & $\begin{array}{l}\text { PD demonstrated greater rotation of } \\
\text { head and trunk versus HC }\end{array}$ & Fair \\
\hline $\begin{array}{l}37 \\
38 \\
39 \\
40 \\
41\end{array}$ & $\begin{array}{l}\text { Carpinella } \\
2007\end{array}$ & $\begin{array}{l}\text { Cross- } \\
\text { sectional }\end{array}$ & $6 \mathrm{PD}$ & $\begin{array}{l}\text { Inc: PD, UPDRS part } \\
\text { III score } 12-20 \\
\text { Exc: } N / R\end{array}$ & $\begin{array}{l}\text { Quantitatively describe } \\
\text { locomotor symptoms in } \\
\text { mild PD }\end{array}$ & $\begin{array}{l}\text { Kinematic } \\
\text { analysis } \\
\text { Force plate }\end{array}$ & $\begin{array}{l}\text { Early stage of PD had mild alterations } \\
\text { of steady-state linear walking and in } \\
\text { transitional conditions during direction } \\
\text { changes }\end{array}$ & Fair \\
\hline
\end{tabular}




\begin{tabular}{|c|c|c|c|c|c|c|c|c|}
\hline & Ferrarin 2002 & $\begin{array}{l}\text { Cross- } \\
\text { sectional }\end{array}$ & $\begin{array}{l}4 \mathrm{PD} \\
4 \mathrm{HC}\end{array}$ & $\begin{array}{l}\text { Inc: PD, STN DBS } \\
\text { Exc: N/R }\end{array}$ & $\begin{array}{l}\text { Assess gait changes } \\
\text { with STN DBS in PD } \\
\text { vs. HC }\end{array}$ & $\begin{array}{l}\text { Kinematic } \\
\text { analysis } \\
\text { Force plate }\end{array}$ & $\begin{array}{l}\text { STN DBS improves gait patterns in PD } \\
\text { but reduces ankle power production } \\
\text { during stimulation }\end{array}$ & Fair \\
\hline 14 & $\begin{array}{l}\text { Van Emmerik } \\
1999\end{array}$ & $\begin{array}{l}\text { Cross- } \\
\text { sectional }\end{array}$ & $\begin{array}{l}27 \mathrm{PD} \\
11 \mathrm{HC}\end{array}$ & $\begin{array}{l}\text { Inc: recent PD } \\
\text { diagnosis } \\
\text { Exc: PD meds }\end{array}$ & $\begin{array}{l}\text { Evaluate coordination } \\
\text { and stability during } \\
\text { walking in PD }\end{array}$ & $\begin{array}{l}\text { Kinematic } \\
\text { analysis }\end{array}$ & $\begin{array}{l}\text { Analysis of changes in velocity during } \\
\text { walking can identify coordination } \\
\text { deficits and trunk rigidity. }\end{array}$ & Fair \\
\hline 12 & Doan 2010 & $\begin{array}{l}\text { Cross- } \\
\text { sectional }\end{array}$ & $\begin{array}{l}10 \mathrm{PD} \\
8 \mathrm{HC}\end{array}$ & $\begin{array}{l}\text { Inc: PD } \\
\text { Exc: } N / R\end{array}$ & $\begin{array}{l}\text { Evaluate standing and } \\
\text { reaching in a } \\
\text { challenging } \\
\text { environmental context }\end{array}$ & Force plate & $\begin{array}{l}\text { PD delayed trunk flexion and peak end- } \\
\text { point velocity }\end{array}$ & Poor \\
\hline & Bleuse 2008 & $\begin{array}{l}\text { Cross- } \\
\text { sectional }\end{array}$ & $\begin{array}{l}10 \mathrm{PD} \\
10 \mathrm{HC}\end{array}$ & $\begin{array}{l}\text { Inc: PD } \\
\text { Exc: } N / R\end{array}$ & $\begin{array}{l}\text { Describe postural } \\
\text { instability in PD vs. HC } \\
\text { during limb movement }\end{array}$ & Force plate & $\begin{array}{l}\text { PD had postural instability prior to limb } \\
\text { movement }\end{array}$ & Poor \\
\hline
\end{tabular}

PD, Parkinson's disease; HC, Healthy control; Inc, Inclusion; Exc, Exclusion; w\&w/o, with and without; N/R, non-reported; min, minutes; REM, Rapid eye movement; DBS, Deep brain stimulation; STN, Subthalamic nucleus; COM, center of mass; COP, center of pressure; H\&Y, Hoehn \& Yahr; MMSE, Mini-Mental State Examination; ROM, range of motion 
Table 2: Eligible Studies Assessing Bradykinesia, Rigidity, and Tremor

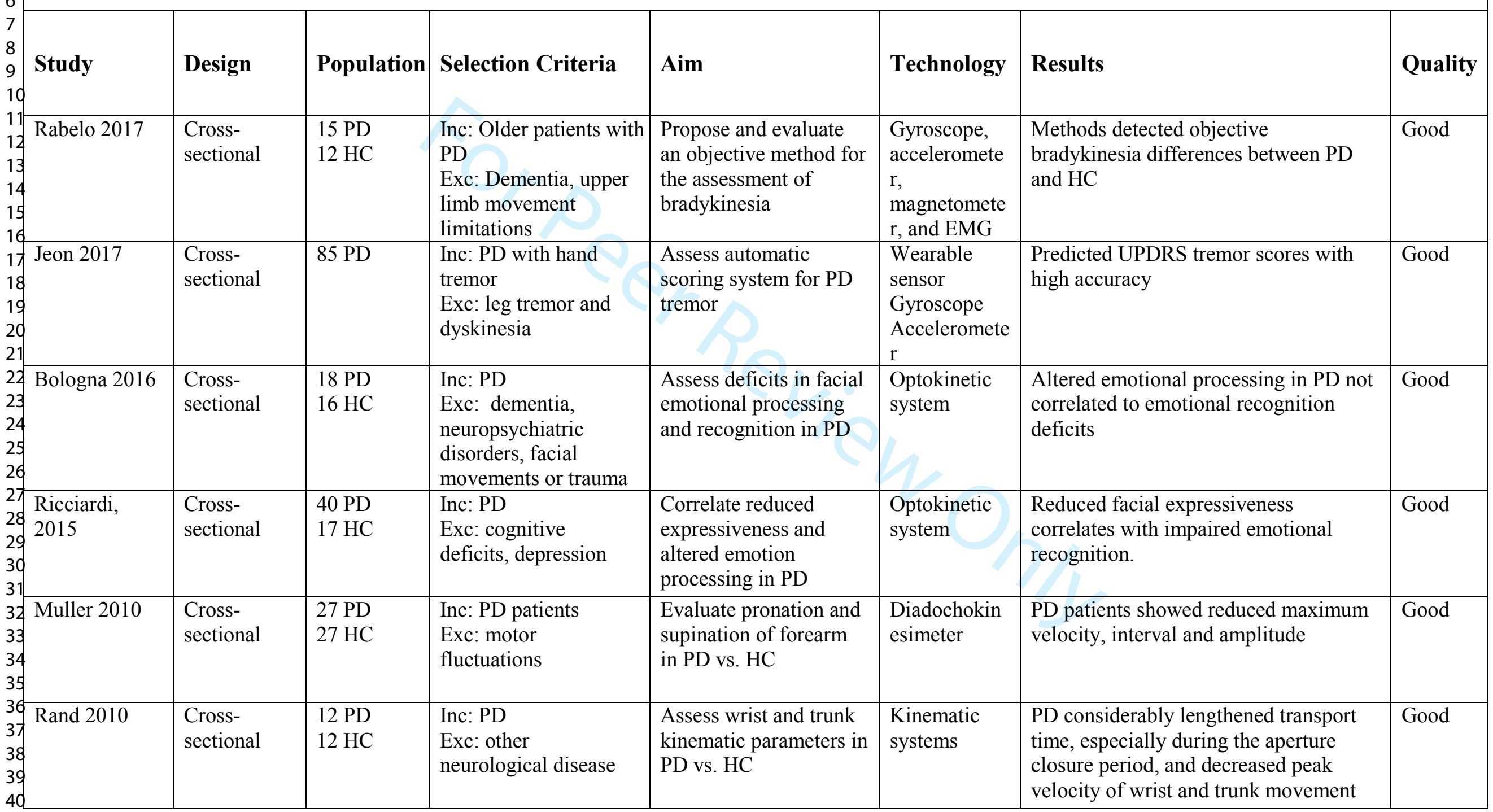


1

\begin{tabular}{|c|c|c|c|c|c|c|c|c|}
\hline 6 & Espay 2009 & $\begin{array}{l}\text { Cross- } \\
\text { sectional }\end{array}$ & $\begin{array}{l}23 \mathrm{PD} \\
16 \mathrm{HC}\end{array}$ & $\begin{array}{l}\text { Inc: PD } \\
\text { Exc: severe tremor, } \\
\text { DBS, cognitive } \\
\text { impairment, } \\
\text { UMN/LMN signs, } \\
\text { atypical parkinsonism }\end{array}$ & $\begin{array}{l}\text { Categorize the } \\
\text { spectrum of movements } \\
\text { in PD in terms of speed } \\
\text { and amplitude }\end{array}$ & $\begin{array}{l}\text { Wearable } \\
\text { motion } \\
\text { sensor }\end{array}$ & $\begin{array}{l}\text { Amplitude and speed impairments may } \\
\text { be associated with different functional } \\
\text { aspects in PD }\end{array}$ & Good \\
\hline $\begin{array}{l}8 \\
9 \\
10 \\
11 \\
12\end{array}$ & Mak 2007 & $\begin{array}{l}\text { Cross- } \\
\text { sectional }\end{array}$ & $\begin{array}{l}21 \mathrm{PD} \\
21 \mathrm{HC}\end{array}$ & $\begin{array}{l}\text { Inc: PD, H\&Y } 2 \text { or } 3 \text {, } \\
\text { stable PD medication } \\
\text { Exc: N/R }\end{array}$ & $\begin{array}{l}\text { Develop an } \\
\text { objective measure to } \\
\text { quantify trunk rigidity i } \\
\text { n PD }\end{array}$ & Force plate & $\begin{array}{l}\text { Method differentiated trunk rigidity in } \\
\text { PD versus HC. There were increases in } \\
\text { work done and resistive peak torques } \\
\text { upon motor tasks }\end{array}$ & Good \\
\hline $\begin{array}{l}13 \\
14 \\
15 \\
16 \\
17\end{array}$ & Castiello 2000 & $\begin{array}{l}\text { Cross- } \\
\text { sectional }\end{array}$ & $\begin{array}{l}14 \mathrm{PD} \\
14 \mathrm{HC}\end{array}$ & $\begin{array}{l}\text { Inc: PD patient; Right } \\
\text { dominance } \\
\text { Exc: Motor } \\
\text { complications due to } \\
\text { therapy }\end{array}$ & $\begin{array}{l}\text { Evaluate reach-to-grasp } \\
\text { movement in PD } \\
\text { patients during ON and } \\
\text { OFF states }\end{array}$ & $\begin{array}{l}\text { Motion } \\
\text { analysis }\end{array}$ & $\begin{array}{l}\text { Dopaminergic medication reduced } \\
\text { bradykinesia and fine-tuning kinematic } \\
\text { movement during reach-to-grasp task }\end{array}$ & Good \\
\hline $\begin{array}{l}18 \\
19 \\
20 \\
21 \\
27\end{array}$ & Lin 2018 & $\begin{array}{l}\text { Cross- } \\
\text { sectional }\end{array}$ & $\begin{array}{l}15 \mathrm{ET} \\
15 \mathrm{PD}\end{array}$ & $\begin{array}{l}\text { Inc: ET or PD } \\
\text { Exc: } N / R\end{array}$ & $\begin{array}{l}\text { Quantify tremor } \\
\text { spatially and } \\
\text { temporally in PD }\end{array}$ & Tablet-based & $\begin{array}{l}\text { Tablet measures of tremor correlates } \\
\text { well with current clinical assessments }\end{array}$ & Fair \\
\hline 23 & Summa 2017 & $\begin{array}{l}\text { Cross- } \\
\text { sectional }\end{array}$ & $\begin{array}{l}7 \mathrm{PD} \\
7 \mathrm{HC}\end{array}$ & $\begin{array}{l}\text { Inc: PD, H\&Y } 1-2.5 \\
\text { Exc: movement } \\
\text { limitations for } \\
\text { conditions other than } \\
\text { PD }\end{array}$ & $\begin{array}{l}\text { Analyze the kinematic } \\
\text { and dynamic } \\
\text { characteristics of goal- } \\
\text { directed movements }\end{array}$ & $\begin{array}{l}\text { Kinematic } \\
\text { analysis }\end{array}$ & $\begin{array}{l}\text { Prono-supination task is consistent to } \\
\text { quantify bradykinesia with } \\
\text { gyroscopes. Peak power seems } \\
\text { appropriate for bradykinesia symptom } \\
\text { evaluation. }\end{array}$ & Fair \\
\hline $\begin{array}{l}29 \\
30 \\
31 \\
32 \\
32\end{array}$ & $\begin{array}{l}\text { Heremans } \\
2016\end{array}$ & $\begin{array}{l}\text { Cross- } \\
\text { sectional }\end{array}$ & $\begin{array}{l}30 \mathrm{PD} \\
15 \mathrm{HC}\end{array}$ & $\begin{array}{l}\text { Inc: PD, H\&Y } 1 \text { - } 3 \\
\text { Exc: depression, } \\
\text { neurological } \\
\text { comorbidities }\end{array}$ & $\begin{array}{l}\text { Assess writing quality } \\
\text { in PD with and without } \\
\text { FOG }\end{array}$ & Tablet-based & $\begin{array}{l}\text { Patients with FOG showed decreased } \\
\text { writing amplitudes and increased } \\
\text { variability compared to HC and PD w/o } \\
\text { FOG }\end{array}$ & Fair \\
\hline $\begin{array}{l}33 \\
34 \\
35 \\
36 \\
34\end{array}$ & Fraiwan 2016 & $\begin{array}{l}\text { Cross- } \\
\text { sectional }\end{array}$ & $\begin{array}{l}21 \mathrm{PD} \\
21 \mathrm{HC}\end{array}$ & $\begin{array}{l}\text { Inc: PD } \\
\text { Exc: N/R }\end{array}$ & $\begin{array}{l}\text { Detect and quantify } \\
\text { hand tremor in PD }\end{array}$ & $\begin{array}{l}\text { Acceleromete } \\
\mathrm{r}\end{array}$ & $\begin{array}{l}\text { Detected hand tremor and diagnosed PD } \\
\text { with high accuracy }\end{array}$ & Fair \\
\hline $\begin{array}{l}38 \\
39 \\
40 \\
41 \\
42\end{array}$ & $\begin{array}{l}\text { Van Gilst } \\
2015\end{array}$ & Case-control & $\begin{array}{l}36 \mathrm{PD} \\
\text { w\&w/o } \\
\text { sleep benefit }\end{array}$ & $\begin{array}{l}\text { Inc: PD } \\
\text { Exc: psychiatric } \\
\text { diagnosis, DBS, other } \\
\text { neurological disease, } \\
\text { hypnotics }\end{array}$ & $\begin{array}{l}\text { Evaluate the influence } \\
\text { of sleep on motor } \\
\text { functioning in PD }\end{array}$ & $\begin{array}{l}\text { PSG } \\
\text { dexterity } \\
\text { pegboard }\end{array}$ & $\begin{array}{l}\text { Sleep benefit is not paralleled by an } \\
\text { actual improvement in motor functioning }\end{array}$ & Fair \\
\hline
\end{tabular}




\begin{tabular}{|c|c|c|c|c|c|c|c|c|}
\hline $\begin{array}{l}2 \\
3 \\
4\end{array}$ & $\begin{array}{l}\text { Thanawattano } \\
2015\end{array}$ & $\begin{array}{l}\text { Cross- } \\
\text { sectional }\end{array}$ & $\begin{array}{l}22 \mathrm{ET} \\
35 \mathrm{PD}\end{array}$ & $\begin{array}{l}\text { Inc: ET or PD } \\
\text { Exc: } N / R\end{array}$ & $\begin{array}{l}\text { Assess tremor in time } \\
\text { domain ('temporal } \\
\text { fluctuation') }\end{array}$ & $\begin{array}{l}\text { Wearable } \\
\text { sensor } \\
\text { gyroscope }\end{array}$ & $\begin{array}{l}\text { Temporal fluctuation distinguishes } \\
\text { tremor in PD and ET }\end{array}$ & Fair \\
\hline $\begin{array}{l}6 \\
7 \\
8 \\
9 \\
10\end{array}$ & $\begin{array}{l}\text { Thanawattano } \\
2015\end{array}$ & $\begin{array}{l}\text { Cross- } \\
\text { sectional }\end{array}$ & $\begin{array}{l}32 \mathrm{PD} \\
20 \mathrm{ET}\end{array}$ & $\begin{array}{l}\text { Inc: PD or ET } \\
\text { Exc: } N / R\end{array}$ & $\begin{array}{l}\text { Quantify tremor } \\
\text { fluctuation during } \\
\text { resting and kinetic tasks } \\
\text { in PD }\end{array}$ & Gyroscope & $\begin{array}{l}\text { Tremor fluctuation can distinguish PD } \\
\text { from ET tremor }\end{array}$ & Fair \\
\hline $\begin{array}{l}11 \\
12 \\
13 \\
14 \\
15 \\
16\end{array}$ & Kotschet 2014 & $\begin{array}{l}\text { Cross- } \\
\text { sectional }\end{array}$ & $\begin{array}{l}68 \mathrm{PD} \\
30 \mathrm{HC}\end{array}$ & $\begin{array}{l}\text { Inc: levodopa } \\
\text { responsive PD } \\
\text { Exc: } N / R\end{array}$ & $\begin{array}{l}\text { Evaluate relationship } \\
\text { between episodes of } \\
\text { sleep immobility to } \\
\text { bradykinesia, } \\
\text { dyskinesia and daytime } \\
\text { sleepiness }\end{array}$ & $\begin{array}{l}\text { Acceleromete } \\
\mathrm{r}\end{array}$ & $\begin{array}{l}\text { Immobility is a marker of daytime sleep } \\
\text { in PD }\end{array}$ & Fair \\
\hline $\begin{array}{l}17 \\
18 \\
19 \\
20 \\
21\end{array}$ & $\begin{array}{l}\text { Cano-de-la- } \\
\text { Cuerda, } 2014\end{array}$ & $\begin{array}{l}\text { Cross- } \\
\text { sectional }\end{array}$ & $36 \mathrm{PD}$ & $\begin{array}{l}\text { Inc: PD with good } \\
\text { walking ability } \\
\text { Exc: Dementia, } \\
\text { depression }\end{array}$ & $\begin{array}{l}\text { Quantify trunk rigidity } \\
\text { in } \mathrm{PD}\end{array}$ & $\begin{array}{l}\text { Dynamomete } \\
\mathrm{r}\end{array}$ & $\begin{array}{l}\text { Trunk rigidity correlates with disease } \\
\text { severity, disease duration, functional } \\
\text { status }\end{array}$ & Fair \\
\hline 22 & Jobbágy 2004 & $\begin{array}{l}\text { Cross- } \\
\text { sectional }\end{array}$ & $\begin{array}{l}10 \mathrm{PD} \\
32 \mathrm{HC}\end{array}$ & $\begin{array}{l}\text { Inc: } N / R \\
\text { Exc: } N / R\end{array}$ & $\begin{array}{l}\text { Evaluate finger-tapping } \\
\text { in PD }\end{array}$ & $\begin{array}{l}\text { Kinematic } \\
\text { systems }\end{array}$ & $\begin{array}{l}\text { Wearable sensor detected decreased } \\
\text { amplitude of finger-tapping in PD }\end{array}$ & Fair \\
\hline $\begin{array}{l}26 \\
27 \\
28 \\
29 \\
30 \\
31\end{array}$ & Fimbel 2003 & $\begin{array}{l}\text { Cross- } \\
\text { sectional }\end{array}$ & $\begin{array}{l}18 \mathrm{PD} \\
18 \mathrm{HC}\end{array}$ & $\begin{array}{l}\text { Inc: PD, atypical } \\
\text { parkinsonism, right } \\
\text { handed } \\
\text { Exc: neurological } \\
\text { comorbidities }\end{array}$ & $\begin{array}{l}\text { Assess a qualitative } \\
\text { pattern-matching } \\
\text { technique for detecting } \\
\text { events in movement } \\
\text { recordings }\end{array}$ & $\begin{array}{l}\text { Motion } \\
\text { analysis }\end{array}$ & $\begin{array}{l}\text { Reaction time and movement length } \\
\text { were similar in PD and HC, but PD } \\
\text { reached lower maximum speeds longer } \\
\text { execution times than HC. }\end{array}$ & Fair \\
\hline $\begin{array}{l}32 \\
33 \\
34 \\
35\end{array}$ & Zeuner 2003 & $\begin{array}{l}\text { Cross- } \\
\text { sectional }\end{array}$ & $\begin{array}{l}12 \mathrm{PD} \\
11 \mathrm{ET} \\
6 \\
\text { psychogenic }\end{array}$ & $\begin{array}{l}\text { Inc: } N / R \\
\text { Exc: } N / R\end{array}$ & $\begin{array}{l}\text { Measure frequency } \\
\text { changes during tapping }\end{array}$ & EMG & $\begin{array}{l}\text { Absolute change in tremor frequency } \\
\text { and marked intraindividual variability } \\
\text { with tapping in psychogenic tremor }\end{array}$ & Fair \\
\hline $\begin{array}{l}36 \\
37 \\
38 \\
30\end{array}$ & Kelly 2002 & $\begin{array}{l}\text { Cross- } \\
\text { sectional }\end{array}$ & $\begin{array}{l}9 \mathrm{PD} \\
9 \mathrm{HC}\end{array}$ & $\begin{array}{l}\text { Inc: } N / R \\
\text { Exc: } N / R\end{array}$ & $\begin{array}{l}\text { Examine the impact of } \\
\text { levodopa } \\
\text { on the voluntary } \\
\text { movements in PD }\end{array}$ & $\begin{array}{l}\text { Kinematic } \\
\text { systems }\end{array}$ & $\begin{array}{l}\text { PD patients increase reach velocity } \\
\text { and decrease movement time after } \\
\text { taking levodopa }\end{array}$ & Fair \\
\hline
\end{tabular}




\begin{tabular}{|c|c|c|c|c|c|c|c|c|}
\hline 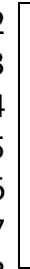 & Martin 2002 & $\begin{array}{l}\text { Cross- } \\
\text { sectional }\end{array}$ & $\begin{array}{l}12 \mathrm{PD} \\
28 \mathrm{HC}\end{array}$ & $\begin{array}{l}\text { Inc: PD; H\&Y } 1 \text { to } 3 \\
\text { Exc: acute illnesses, } \\
\text { OH }\end{array}$ & $\begin{array}{l}\text { Evaluate distance } \\
\text { between the vertical } \\
\text { projections of the COM } \\
\text { and the COP to reflect } \\
\text { postural control during } \\
\text { gait initiation }\end{array}$ & $\begin{array}{l}\text { Kinematic } \\
\text { systems }\end{array}$ & $\begin{array}{l}\text { PD patients allow less COM-COP } \\
\text { distance than HC }\end{array}$ & Fair \\
\hline 3 & $\begin{array}{l}\text { Wenzelburger } \\
2000\end{array}$ & $\begin{array}{l}\text { Cross- } \\
\text { sectional }\end{array}$ & $\begin{array}{l}13 \mathrm{PD} \\
12 \mathrm{HC}\end{array}$ & $\begin{array}{l}\text { Inc: } H \& Y \text { 1to } 3 \text {, hand } \\
\text { rest tremor } \\
\text { Exc: N/R }\end{array}$ & $\begin{array}{l}\text { Evaluate kinetic tremor } \\
\text { (reach a target) in } \\
\text { tremor-dominant PD }\end{array}$ & $\begin{array}{l}\text { Acceleromete } \\
\mathrm{r} \\
\text { EMG } \\
\text { Kinematic } \\
\text { systems }\end{array}$ & $\begin{array}{l}\text { Accelerometer detected greater } \\
\text { frequency of kinetic tremor before the } \\
\text { onset of the movement in PD }\end{array}$ & Fair \\
\hline 5 & Johnson 1994 & $\begin{array}{l}\text { Cross- } \\
\text { sectional }\end{array}$ & $20 \mathrm{PD}$ & $\begin{array}{l}\text { Inc: } N / R \\
\text { Exc: } N / R\end{array}$ & $\begin{array}{l}\text { Examine the acute } \\
\text { change in motor } \\
\text { performance after } \\
\text { Levodopa }\end{array}$ & $\begin{array}{l}\text { Kinematic } \\
\text { systems }\end{array}$ & $\begin{array}{l}\text { Levodopa increase velocity in self- } \\
\text { paced tasks }\end{array}$ & Fair \\
\hline 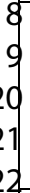 & $\begin{array}{l}\text { Svensonn } \\
1993\end{array}$ & $\begin{array}{l}\text { Cross- } \\
\text { sectional }\end{array}$ & $\begin{array}{l}9 \mathrm{PD} \\
9 \mathrm{HC}\end{array}$ & $\begin{array}{l}\text { Inc: PD } \\
\text { Exc: Poor dental status }\end{array}$ & $\begin{array}{l}\text { Analyze jaw movement } \\
\text { characteristics in PD } \\
\text { during the ON versus } \\
\text { OFF motor state }\end{array}$ & $\begin{array}{l}\text { Motion } \\
\text { analysis }\end{array}$ & $\begin{array}{l}\text { Motion analysis detected differences } \\
\text { between ON and OFF motor states } \\
\text { during a syllable repetition task }\end{array}$ & Fair \\
\hline 3 & Popovic 2008 & $\begin{array}{l}\text { Cross- } \\
\text { sectional }\end{array}$ & 8 PD & $\begin{array}{l}\text { Inc: PD } \\
\text { Exc: } N / R\end{array}$ & $\begin{array}{l}\text { Describe hand motor } \\
\text { blocks in PD using a } \\
\text { digitizing tablet }\end{array}$ & Tablet-based & $\begin{array}{l}\text { Digitizing tablet can be used to record } \\
\text { sudden discontinuations during planar } \\
\text { movements in PD }\end{array}$ & Poor \\
\hline 2 & $\begin{array}{l}\text { Vaillancourt } \\
2000\end{array}$ & $\begin{array}{l}\text { Cross- } \\
\text { sectional }\end{array}$ & $\begin{array}{l}8 \mathrm{PD} \\
8 \mathrm{HC}\end{array}$ & $\begin{array}{l}\text { Inc: no clinical signs of } \\
\text { tremor } \\
\text { Exc: N/R }\end{array}$ & $\begin{array}{l}\text { Examine tremor } \\
\text { features in PD }\end{array}$ & $\begin{array}{l}\text { Acceleromete } \\
\mathrm{r} \\
\text { EMG }\end{array}$ & $\begin{array}{l}\text { PD tremor was more regular vs. } \\
\text { physiological tremor in } \mathrm{HC}\end{array}$ & Poor \\
\hline
\end{tabular}

PD, Parkinson's disease; HC, Healthy control; Inc, Inclusion; Exc, Exclusion; w\&w/o, with and without; N/R, non-reported; DBS, Deep brain stimulation; STN, Subthalamic nucleus; EMG, Electromyography; UMN, upper motor neuron; LMN, lower motor neuron; COM, center of mass; COP, center of pressure; H\&Y, Hoehn \& Yahr; FOG, freezing of gait 


\begin{tabular}{|c|c|c|c|c|c|c|c|}
\hline Study & Design & Population & Selection Criteria & Aim & Technology & Results & Quality \\
\hline $\begin{array}{l}\text { Godino- } \\
\text { Llorente } 2017\end{array}$ & $\begin{array}{l}\text { Cross- } \\
\text { sectional }\end{array}$ & $\begin{array}{l}50 \mathrm{PD} \\
50 \mathrm{HC}\end{array}$ & $\begin{array}{l}\text { Inc: PD } \\
\text { Exc: other } \\
\text { neurological disorders }\end{array}$ & $\begin{array}{l}\text { Assess speech } \\
\text { biomarkers to evaluate } \\
\text { PD }\end{array}$ & $\begin{array}{l}\text { Speech } \\
\text { analysis }\end{array}$ & $\begin{array}{l}\text { Articulatory biomarkers accurately } \\
\text { identify PD }\end{array}$ & Good \\
\hline $\begin{array}{l}\text { Vaiciukynas } \\
2017\end{array}$ & $\begin{array}{l}\text { Cross- } \\
\text { sectional }\end{array}$ & $\begin{array}{l}64 \mathrm{PD} \\
35 \mathrm{HC}\end{array}$ & $\begin{array}{l}\text { Inc: PD } \\
\text { Exc: } N / R\end{array}$ & $\begin{array}{l}\text { Assess sustained } \\
\text { phonation for diagnosis } \\
\text { of PD }\end{array}$ & $\begin{array}{l}\text { Speech } \\
\text { analysis }\end{array}$ & $\begin{array}{l}\text { Acoustic analysis can accurately detect } \\
\text { PD }\end{array}$ & Good \\
\hline Markser 2015 & Case-control & $\begin{array}{l}30 \mathrm{PD} \\
\text { w\&w/o } \\
\text { cognitive } \\
\text { impairment }\end{array}$ & $\begin{array}{l}\text { Inc: DBS indication } \\
\text { Exc: N/R }\end{array}$ & EEG metrics after DBS & EEG & $\begin{array}{l}\text { STN-DBS has a negative effect on the } \\
\text { patients grand total EEG scores }\end{array}$ & Good \\
\hline Arora 2015 & Cohort & $\begin{array}{l}10 \mathrm{PD} \\
10 \mathrm{HC}\end{array}$ & $\begin{array}{l}\text { Inc: PD } \\
\text { Exc:N/R }\end{array}$ & $\begin{array}{l}\text { Assess if symptom } \\
\text { recordings can } \\
\text { differentiate PD vs. HC }\end{array}$ & $\begin{array}{l}\text { Tablet-based } \\
\text { Speech } \\
\text { analysis } \\
\text { Gyroscope } \\
\text { Acceleromete } \\
\text { r }\end{array}$ & $\begin{array}{l}\text { PD symptoms can be feasibly measured } \\
\text { via smartphone }\end{array}$ & Good \\
\hline $\begin{array}{l}\text { Nojszewska } \\
2009\end{array}$ & $\begin{array}{l}\text { Cross- } \\
\text { sectional }\end{array}$ & $\begin{array}{l}46 \mathrm{PD} \\
14 \mathrm{HC}\end{array}$ & $\begin{array}{l}\text { Inc: PD } \\
\text { Exc: severe illness, } \\
\text { deafness }\end{array}$ & $\begin{array}{l}\text { Neuropsychological } \\
\text { test relation } \\
\text { determination to AEP }\end{array}$ & AEP & $\begin{array}{l}\text { AEP of different latencies are helpful in } \\
\text { the assessment of cognitive changes } \\
\text { associated with PD. }\end{array}$ & Good \\
\hline Tanaka 2018 & $\begin{array}{l}\text { Cross- } \\
\text { sectional }\end{array}$ & $137 \mathrm{PD}$ & $\begin{array}{l}\text { Inc: PD with } \\
\text { ambulatory and } \mathrm{OH} \\
\text { data } \\
\text { Exc: acute illnesses }\end{array}$ & $\begin{array}{l}\text { Assess relationship } \\
\text { between nocturnal BP } \\
\text { and dementia in PD }\end{array}$ & $\begin{array}{l}\text { 24-hour } \\
\text { ambulatory } \\
\text { BP and heart } \\
\text { rate }\end{array}$ & $\begin{array}{l}\text { Nocturnal BP rise and } \mathrm{OH} \text { correlated } \\
\text { with dementia }\end{array}$ & Fair \\
\hline
\end{tabular}


1

\begin{tabular}{|c|c|c|c|c|c|c|c|c|}
\hline 2 & Gauvin 2017 & $\begin{array}{l}\text { Cross- } \\
\text { sectional }\end{array}$ & $\begin{array}{l}18 \mathrm{PD} \\
16 \mathrm{HC}\end{array}$ & $\begin{array}{l}\text { Inc: PD } \\
\text { Exc: other neurological } \\
\text { disorders }\end{array}$ & $\begin{array}{l}\text { Assessed verbal } \\
\text { monitoring in PD }\end{array}$ & $\begin{array}{l}\text { Speech } \\
\text { analysis }\end{array}$ & $\begin{array}{l}\text { PD has different verbal monitoring } \\
\text { patterns and greater impairment vs. HC }\end{array}$ & Fair \\
\hline 10 & Latreille 2016 & $\begin{array}{l}\text { Prospective } \\
\text { cohort }\end{array}$ & $\begin{array}{l}68 \mathrm{PD} \\
44 \mathrm{HC}\end{array}$ & $\begin{array}{l}\text { Inc: PD } \\
\text { Exclusion: dementia, } \\
\text { stroke, epilepsy }\end{array}$ & $\begin{array}{l}\text { Prediction of PDD by } \\
\text { PSG }\end{array}$ & PSG & $\begin{array}{l}\text { PD patients who developed PDD had } \\
\text { higher slowing ratio in temporal, } \\
\text { parietal, and occipital regions during } \\
\text { REM sleep }\end{array}$ & Fair \\
\hline $\begin{array}{l}11 \\
12 \\
13 \\
14\end{array}$ & $\begin{array}{l}\text { Rektorova } \\
2016\end{array}$ & Cohort & $44 \mathrm{PD}$ & $\begin{array}{l}\text { Inc: PD } \\
\text { Exc: depression }\end{array}$ & $\begin{array}{l}\text { Assessed relationship } \\
\text { between speech } \\
\text { impairment and } \\
\text { cognitive decline }\end{array}$ & $\begin{array}{l}\text { Speech } \\
\text { analysis }\end{array}$ & $\begin{array}{l}\text { Impairment of speech prosody predicted } \\
\text { rapid cognitive decline }\end{array}$ & Fair \\
\hline $\begin{array}{l}15 \\
16 \\
17 \\
18 \\
19\end{array}$ & $\begin{array}{l}\text { Zimmermann } \\
2015\end{array}$ & $\begin{array}{l}\text { Cross- } \\
\text { sectional }\end{array}$ & $48 \mathrm{PD}$ & $\begin{array}{l}\text { Inc: PD } \\
\text { Exc: dementia, stroke, } \\
\text { epilepsy, low-quality } \\
\text { EEG }\end{array}$ & $\begin{array}{l}\text { Test EEG slowing } \\
\text { relation to cognitive } \\
\text { performance }\end{array}$ & EEG & $\begin{array}{l}\text { Global EEG slowing is a marker for } \\
\text { overall cognitive impairment and } \\
\text { specific domains }\end{array}$ & Fair \\
\hline $\begin{array}{l}20 \\
21 \\
22 \\
23 \\
24\end{array}$ & Latreille 2015 & $\begin{array}{l}\text { Prospective } \\
\text { cohort }\end{array}$ & $\begin{array}{l}68 \mathrm{PD} \\
\text { w\&w/o } \\
\text { cognitive } \\
\text { impairment } \\
47 \mathrm{HC} \\
\end{array}$ & $\begin{array}{l}\text { Inc: PD } \\
\text { Exc: dementia, stroke, } \\
\text { epilepsy }\end{array}$ & $\begin{array}{l}\text { Test PSG prediction of } \\
\text { dementia }\end{array}$ & PSG & $\begin{array}{l}\text { Sleep spindle alterations related to } \\
\text { dementia development }\end{array}$ & Fair \\
\hline $\begin{array}{l}25 \\
26 \\
27 \\
28 \\
29 \\
30 \\
31\end{array}$ & Fischer 2010 & $\begin{array}{l}\text { Cross- } \\
\text { sectional }\end{array}$ & $\begin{array}{l}10 \mathrm{PD} \\
9 \mathrm{HC}\end{array}$ & $\begin{array}{l}\text { Inc: English native } \\
\text { speakers } \\
\text { Exc: dementia, } \\
\text { depression, serious } \\
\text { illness, speech } \\
\text { impairment }\end{array}$ & $\begin{array}{l}\text { Examine voice onset } \\
\text { measures in PD }\end{array}$ & $\begin{array}{l}\text { Voice } \\
\text { analysis }\end{array}$ & $\begin{array}{l}\text { PD medication had an effect on voice } \\
\text { onset time change }\end{array}$ & Fair \\
\hline $\begin{array}{l}32 \\
32 \\
33 \\
34 \\
35\end{array}$ & Fonseca 2009 & $\begin{array}{l}\text { Cross- } \\
\text { sectional }\end{array}$ & $\begin{array}{l}32 \mathrm{PD} \\
26 \mathrm{HC}\end{array}$ & $\begin{array}{l}\text { Inc: PD } \\
\text { Exc: antipsychotics, } \\
\text { benzodiazepines }\end{array}$ & $\begin{array}{l}\text { Evaluate relation } \\
\text { between quantitative } \\
\text { EEG and cognitive } \\
\text { disturbance }\end{array}$ & EEG & $\begin{array}{l}\text { EEG abnormalities were associated } \\
\text { with mild cognitive impairment or } \\
\text { dementia in PD versus HC }\end{array}$ & Fair \\
\hline $\begin{array}{l}36 \\
37 \\
38 \\
39\end{array}$ & Matsui 2007 & $\begin{array}{l}\text { Cross- } \\
\text { sectional }\end{array}$ & $\begin{array}{l}40 \mathrm{PD} \\
\text { w\&w/o } \\
\text { dementia }\end{array}$ & $\begin{array}{l}\text { Inc: } H \& Y 3 \text { or } 4 \\
\text { Exc: atypical } \\
\text { parkinsonism }\end{array}$ & $\begin{array}{l}\text { Examine P300 } \\
\text { differences between } \\
\text { PDD and PD }\end{array}$ & EEG & $\begin{array}{l}\text { P300 latency was markedly delayed in } \\
\text { PDD patients }\end{array}$ & Fair \\
\hline
\end{tabular}




\begin{tabular}{|c|c|c|c|c|c|c|c|c|}
\hline $\begin{array}{l}2 \\
3 \\
4 \\
5 \\
6 \\
7\end{array}$ & Bunton 2005 & $\begin{array}{l}\text { Cross- } \\
\text { sectional }\end{array}$ & $\begin{array}{l}7 \mathrm{PD} \\
6 \mathrm{HC}\end{array}$ & $\begin{array}{l}\text { Inc: PD, English native } \\
\text { speaker } \\
\text { Exc: dementia, } \\
\text { hypoacusia }\end{array}$ & $\begin{array}{l}\text { Determine patterns of } \\
\text { lung volume use in PD } \\
\text { during an } \\
\text { extemporaneous } \\
\text { speaking task }\end{array}$ & $\begin{array}{l}\text { Microphone, } \\
\text { magnetomete } \\
\mathrm{r}\end{array}$ & $\begin{array}{l}\text { Speakers with PD began speaking at } \\
\text { lower lung volumes and had an } \\
\text { increased variability in starting lung } \\
\text { volumes across the speech sample } \\
\text { versus HC }\end{array}$ & Fair \\
\hline $\begin{array}{l}8 \\
9 \\
10 \\
11 \\
12\end{array}$ & Katsarou 2004 & $\begin{array}{l}\text { Cross- } \\
\text { sectional }\end{array}$ & $\begin{array}{l}45 \mathrm{PD} \\
40 \mathrm{HC}\end{array}$ & $\begin{array}{l}\text { Inc: PD, MMSE }>25 \text {, } \\
\text { H\&Y } 2 \text { to } 3 \\
\text { Exc: dementia }\end{array}$ & $\begin{array}{l}\text { Compare P300 between } \\
\text { PD patients and HC }\end{array}$ & EEG & $\begin{array}{l}\text { Non-demented PD patients had a } \\
\text { prolonged P300 latency versus HC }\end{array}$ & Fair \\
\hline $\begin{array}{l}13 \\
14 \\
15 \\
16\end{array}$ & Antal 2000 & $\begin{array}{l}\text { Cross- } \\
\text { sectional }\end{array}$ & $\begin{array}{l}20 \mathrm{PD} \\
20 \mathrm{ET} \\
20 \mathrm{HC}\end{array}$ & $\begin{array}{l}\text { Inc: PD or ET } \\
\text { Exc: retinopathy, } \\
\text { glaucoma, DM, } \\
\text { alcoholism }\end{array}$ & $\begin{array}{l}\text { Compare components } \\
\text { of VEP in patients with } \\
\text { PD and ET }\end{array}$ & VEP & No significant overall group difference & Fair \\
\hline $\begin{array}{l}17 \\
18 \\
19 \\
20 \\
21\end{array}$ & Hawkes 1997 & $\begin{array}{l}\text { Cross- } \\
\text { sectional }\end{array}$ & $\begin{array}{l}37 \mathrm{PD} \\
47 \mathrm{HC}\end{array}$ & $\begin{array}{l}\text { Inc: PD, MMSE }>26, \\
\text { Exc: head trauma, DM, } \\
\text { alcoholism }\end{array}$ & $\begin{array}{l}\text { Evaluate olfactory } \\
\text { function in PD }\end{array}$ & $\begin{array}{l}\text { UPSIT, } \\
\text { Olfactory } \\
\text { evoked } \\
\text { potentials }\end{array}$ & $\begin{array}{l}\text { Over } 70 \% \text { of PD were abnormal. The } \\
\text { evoked potentials were significantly } \\
\text { delayed but comparable to HC. }\end{array}$ & Fair \\
\hline $\begin{array}{l}22 \\
23 \\
24 \\
25 \\
26 \\
27\end{array}$ & $\begin{array}{l}\text { Sagliocco } \\
1997\end{array}$ & $\begin{array}{l}\text { Cross- } \\
\text { sectional }\end{array}$ & $\begin{array}{l}17 \mathrm{PD} \\
17 \mathrm{HC}\end{array}$ & $\begin{array}{l}\text { Inc: } P D, M M S E \geq 23, \\
\text { visual acuity } \geq 20 / 40, \\
\text { Exc: unable to } \\
\text { cooperate }\end{array}$ & $\begin{array}{l}\text { Compare } \\
\text { simultaneously } \\
\text { recorded VEP and } \\
\text { event related potentials } \\
\text { in PD }\end{array}$ & $\begin{array}{l}\text { VEP } \\
\text { EEG }\end{array}$ & $\begin{array}{l}\text { Simultaneous VEP and visual event } \\
\text { related potentials recordings are } \\
\text { helpful to distinguish younger PD } \\
\text { patients from HC }\end{array}$ & Fair \\
\hline $\begin{array}{l}28 \\
29 \\
30 \\
31 \\
32\end{array}$ & Green 1996 & $\begin{array}{l}\text { Cross- } \\
\text { sectional }\end{array}$ & $\begin{array}{l}20 \mathrm{PD} \\
20 \mathrm{HC}\end{array}$ & $\begin{array}{l}\text { Inc: PD } \\
\text { Exc: depression }\end{array}$ & $\begin{array}{l}\text { Understand P3- } \\
\text { associated variability in } \\
\text { PD }\end{array}$ & EEG & $\begin{array}{l}\text { P3 amplitude may be more sensitive } \\
\text { than neuropsychological measures for } \\
\text { subtle brain dysfunction in early PD }\end{array}$ & Fair \\
\hline $\begin{array}{l}34 \\
33 \\
34 \\
35 \\
36\end{array}$ & $\begin{array}{l}\text { Pekkonen } \\
1995\end{array}$ & $\begin{array}{l}\text { Cross- } \\
\text { sectional }\end{array}$ & $\begin{array}{l}13 \mathrm{PD} \\
11 \mathrm{HC}\end{array}$ & $\begin{array}{l}\text { Inc: PD } \\
\text { Exc: severe illness, } \\
\text { deafness }\end{array}$ & $\begin{array}{l}\text { Determine stimulus } \\
\text { change impairment in } \\
\text { PD }\end{array}$ & EEG & $\begin{array}{l}\text { Mismatch negativity of event-related } \\
\text { potentials are smaller in PD versus } \mathrm{HC}\end{array}$ & Fair \\
\hline $\begin{array}{l}37 \\
38 \\
39 \\
40 \\
41\end{array}$ & Okuda 1995 & Case-control & $\begin{array}{l}32 \mathrm{PD} \\
22 \mathrm{HC}\end{array}$ & $\begin{array}{l}\text { Inc: visual acuity }>0.7 \\
\text { Exc: ophthalmological } \\
\text { disease }\end{array}$ & $\begin{array}{l}\text { Measure differences in } \\
\text { VEP in PD, PDD, and } \\
\text { HC }\end{array}$ & VEP & $\begin{array}{l}\text { PDD has prolonged P100 latencies } \\
\text { versus both non-demented PD and HC }\end{array}$ & Fair \\
\hline
\end{tabular}


1

\begin{tabular}{|c|c|c|c|c|c|c|c|c|}
\hline $\begin{array}{l}2 \\
3\end{array}$ & Kim 1995 & $\begin{array}{l}\text { Cross- } \\
\text { sectional }\end{array}$ & $\begin{array}{l}16 \mathrm{PD} \\
15 \mathrm{HC}\end{array}$ & $\begin{array}{l}\text { Inc: PD, MMSE }>24 \text {, } \\
\text { Exc: antipsychotics, } \\
\text { brain image lesion }\end{array}$ & $\begin{array}{l}\text { Use P300 as index of } \\
\text { cognitive function in } \\
\text { PD }\end{array}$ & EEG & $\begin{array}{l}\text { P300 was inversely correlated with } \\
\text { performance of visuomotor procedural } \\
\text { memory. }\end{array}$ & Fair \\
\hline $\begin{array}{l}6 \\
7 \\
8 \\
9 \\
10\end{array}$ & Peppe 1995 & $\begin{array}{l}\text { Cross- } \\
\text { sectional }\end{array}$ & $\begin{array}{l}18 \mathrm{PD} \\
8 \mathrm{HC}\end{array}$ & $\begin{array}{l}\text { Inc: de novo PD } \\
\text { Exc: DM, retinopathy }\end{array}$ & $\begin{array}{l}\text { Determine VEP } \\
\text { characteristics in de } \\
\text { novo PD }\end{array}$ & VEP & $\begin{array}{l}\text { PERG P50 and VEP P100 latencies } \\
\text { were increased in de novo PD before } \\
\text { therapy versus HC }\end{array}$ & Fair \\
\hline $\begin{array}{l}11 \\
12 \\
13 \\
14\end{array}$ & $\begin{array}{l}\text { Bodis-Wollner } \\
1995\end{array}$ & $\begin{array}{l}\text { Cross- } \\
\text { sectional }\end{array}$ & $50 \mathrm{PD}$ & $\begin{array}{l}\text { Inc: PD } \\
\text { Exc: dementia, } \\
\text { thalamotomy, } \\
\text { depression }\end{array}$ & $\begin{array}{l}\text { Determine event related } \\
\text { potentials } \\
\text { characteristics in PD }\end{array}$ & EEG & $\begin{array}{l}\text { Longer ERP latencies correlated to } \\
\text { lower scores on tests of cognitive } \\
\text { functioning. }\end{array}$ & Fair \\
\hline $\begin{array}{l}15 \\
16 \\
11 \\
19 \\
19\end{array}$ & Vieregge 1994 & $\begin{array}{l}\text { Cross- } \\
\text { sectional }\end{array}$ & $\begin{array}{l}14 \mathrm{PD} \\
16 \mathrm{HC}\end{array}$ & $\begin{array}{l}\text { Inc: right handed } \\
\text { Exc: depression, } \\
\text { dementia, deafness }\end{array}$ & $\begin{array}{l}\text { Assess selective } \\
\text { auditory attention with } \\
\text { processing negativity in } \\
\text { PD }\end{array}$ & EEG & $\begin{array}{l}\text { Processing negativity smaller in PD } \\
\text { versus } \mathrm{HC} \text { at a rate of } 1 \text { tone/second }\end{array}$ & Fair \\
\hline $\begin{array}{l}20 \\
21 \\
22 \\
23\end{array}$ & Filipovic 2001 & $\begin{array}{l}\text { Cross- } \\
\text { sectional }\end{array}$ & $\begin{array}{l}16 \mathrm{PD} \\
\text { w\&w/o } \\
\text { depression }\end{array}$ & $\begin{array}{l}\text { Inc: PD } \\
\text { Exc: severe tremor, } \\
\text { focal brain lesions }\end{array}$ & $\begin{array}{l}\text { Determine readiness } \\
\text { potential patterns that } \\
\text { distinguish } w \& w / o \\
\text { depression }\end{array}$ & EEG & $\begin{array}{l}\text { Readiness potentials amplitude and } \\
\text { slopes were smaller in PD, but w/o } \\
\text { specific patterns that differentiated } \\
\text { w\&w/o depression }\end{array}$ & Poor \\
\hline $\begin{array}{l}24 \\
25 \\
26 \\
27 \\
28\end{array}$ & Buttner 1996 & $\begin{array}{l}\text { Cross- } \\
\text { sectional }\end{array}$ & $\begin{array}{l}39 \mathrm{PD} \\
43 \mathrm{HC}\end{array}$ & $\begin{array}{l}\text { Inc: PD } \\
\text { Exc: dementia, } \\
\text { retinopathy, daltonism }\end{array}$ & $\begin{array}{l}\text { Assesss chromatic VEP } \\
\text { in PD patient }\end{array}$ & VEP & $\begin{array}{l}\text { VEP demonstrate dysfunction of the } \\
\text { visual system in PD }\end{array}$ & Poor \\
\hline
\end{tabular}

PD, Parkinson's disease; HC, Healthy control; Inc, Inclusion; Exc, Exclusion; w\&w/o, with and without; N/R, non-reported; min, minutes; PDD,

Parkinson's disease dementia; PSG, Polysomnography; DBS, Deep brain stimulation; STN, Subthalamic nucleus; EEG, electroencephalography; VEP,

Visual evoked potentials; AEP, Auditory evoked potentials; DM, Diabetes mellitus; HTN, Hypertension; \& Yahr; MMSE, Mini-Mental State

Examination; OH, orthostatic hypotension; ERP, event related potential; UPSIT, Smell Identification Test 


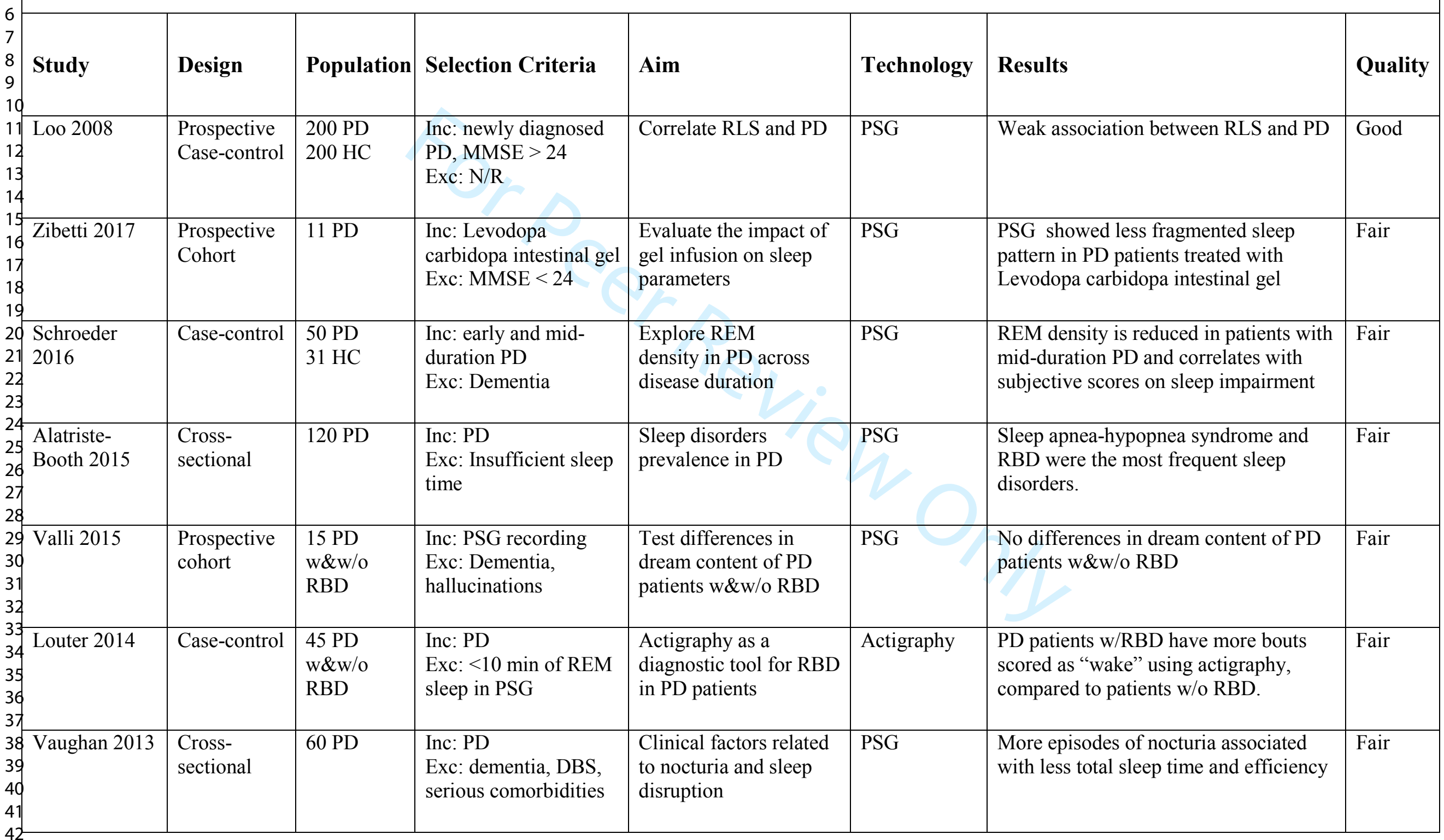

Table 4: Eligible Studies Assessing Sleep 


\begin{tabular}{|c|c|c|c|c|c|c|c|c|}
\hline 2 & Naismith 2010 & $\begin{array}{l}\text { Cross- } \\
\text { sectional }\end{array}$ & $\begin{array}{l}22 \mathrm{PD} \\
\mathrm{w} \& \mathrm{w} / \mathrm{o} \\
\mathrm{RBD}\end{array}$ & $\begin{array}{l}\text { Inc: PD } \\
\text { Exc: } N / R\end{array}$ & $\begin{array}{l}\text { Evaluate actigraphy for } \\
\text { RBD reported by PD } \\
\text { patients }\end{array}$ & Actigraphy & $\begin{array}{l}\text { PD patients } w / \text { RBD have higher number } \\
\text { of wake bouts than PD patients w/o } \\
\text { RBD }\end{array}$ & Fair \\
\hline $\begin{array}{l}6 \\
7 \\
8 \\
9 \\
10\end{array}$ & Shpirer 2006 & $\begin{array}{l}\text { Prospective } \\
\text { cohort }\end{array}$ & $\begin{array}{l}46 \mathrm{PD} \\
30 \mathrm{HC}\end{array}$ & $\begin{array}{l}\text { Inc: PD } \\
\text { Exc: } N / R\end{array}$ & $\begin{array}{l}\text { Compare sleep } \\
\text { characteristics of PD } \\
\text { versus HC }\end{array}$ & PSG & $\begin{array}{l}\text { PD had lower sleep efficiency, longer } \\
\text { Stage } 2 \text { sleep and shorter REM sleep }\end{array}$ & Fair \\
\hline $\begin{array}{l}11 \\
12 \\
13 \\
14\end{array}$ & Dhawan 2006 & $\begin{array}{l}\text { Cross- } \\
\text { sectional }\end{array}$ & $\begin{array}{l}59 \mathrm{PD} \\
131 \mathrm{HC}\end{array}$ & $\begin{array}{l}\text { Inc: } P D, H \& Y 3 \text { to } 5 \\
\text { Exc: } N / R\end{array}$ & $\begin{array}{l}\text { Compare sleep } \\
\text { problems in untreated } \\
\text { PD compared to } \\
\text { advanced PD and HC }\end{array}$ & PSG & $\begin{array}{l}\text { Advanced PD demonstrated PSG } \\
\text { patterns of periodic limb movement } \\
\text { of sleep, obstructive sleep apnea, and } \\
\text { RBD }\end{array}$ & Fair \\
\hline $\begin{array}{l}15 \\
16 \\
17 \\
18 \\
19\end{array}$ & $\begin{array}{l}\text { Diederich } \\
2005\end{array}$ & Case-control & $\begin{array}{l}49 \mathrm{PD} \\
49 \mathrm{HC}\end{array}$ & $\begin{array}{l}\text { Inc: PD } \\
\text { Exc: } N / R\end{array}$ & $\begin{array}{l}\text { Nocturnal respiration } \\
\text { impact on sleep } \\
\text { continuity and } \\
\text { architecture }\end{array}$ & PSG & $\begin{array}{l}\text { In non-obese PD patients, sleep apnea } \\
\text { syndrome is not a major cause for sleep } \\
\text { fragmentation }\end{array}$ & Fair \\
\hline $\begin{array}{l}20 \\
21 \\
22 \\
23 \\
24\end{array}$ & Gagnon 2004 & $\begin{array}{l}\text { Cross- } \\
\text { sectional }\end{array}$ & $15 \mathrm{PD}$ & $\begin{array}{l}\text { Inc: PD, H\&Y } 1 \text { to } 3 \\
\text { Exc: atypical } \\
\text { parkinsonism, } \\
\text { antidepressants, serious } \\
\text { illness }\end{array}$ & $\begin{array}{l}\text { Compare EEG of PD } \\
\text { w\&w/o RBD }\end{array}$ & EEG & $\begin{array}{l}\text { EEG slowing reported during } \\
\text { wakefulness in non-demented PD is } \\
\text { strongly correlated to RBD }\end{array}$ & Fair \\
\hline $\begin{array}{l}25 \\
26 \\
21 \\
28 \\
29\end{array}$ & Cicolin 2004 & $\begin{array}{l}\text { Cross- } \\
\text { sectional }\end{array}$ & $5 \mathrm{PD}$ & $\begin{array}{l}\text { Inc: PD undergoing } \\
\text { DBS } \\
\text { Exc: N/R }\end{array}$ & $\begin{array}{l}\text { Evaluate sleep } \\
\text { architecture } \\
\text { modifications after } \\
\text { STN DBS }\end{array}$ & PSG & $\begin{array}{l}\text { STN DBS increases total sleep time and } \\
\text { reduces wakefulness after sleep onset }\end{array}$ & Fair \\
\hline $\begin{array}{l}30 \\
31 \\
32 \\
33 \\
34 \\
35\end{array}$ & Moller 2002 & $\begin{array}{l}\text { Cross- } \\
\text { sectional }\end{array}$ & $6 \mathrm{PD}$ & $\begin{array}{l}\text { Inc: unusually fast or } \\
\text { sudden onset of sleep, } \\
\text { combined dopamine } \\
\text { agonist + levodopa } \\
\text { Exc: N/R }\end{array}$ & $\begin{array}{l}\text { Investigate nighttime } \\
\text { sleep quality and } \\
\text { degree of daytime } \\
\text { sleepiness in PD } \\
\text { patients with sleep } \\
\text { attacks }\end{array}$ & PSG & $\begin{array}{l}\text { Unusually fast or sudden onset of sleep } \\
\text { in PD patients is a phenomenon of } \\
\text { daytime sleepiness }\end{array}$ & Fair \\
\hline $\begin{array}{l}36 \\
37 \\
38 \\
39\end{array}$ & Gagnon 2002 & $\begin{array}{l}\text { Cross- } \\
\text { sectional }\end{array}$ & $\begin{array}{l}33 \mathrm{PD} \\
16 \mathrm{HC}\end{array}$ & $\begin{array}{l}\text { Inc: } H \& Y 1 \text { to } 3 \text {, use of } \\
\text { dopamine agonists } \\
\text { Exc: atypical signs for } \\
\text { PD diagnosis }\end{array}$ & $\begin{array}{l}\text { Determine the } \\
\text { frequency of RBD } \\
\text { among patients with PD }\end{array}$ & PSG & $\begin{array}{l}\text { A third of patients with PD meet RBD } \\
\text { criteria based on PSG, but only half of } \\
\text { these cases would have been detected } \\
\text { by history taking. }\end{array}$ & Fair \\
\hline
\end{tabular}




\begin{tabular}{|c|c|c|c|c|c|c|c|c|}
\hline 2 & Young 2002 & $\begin{array}{l}\text { Cross- } \\
\text { sectional }\end{array}$ & $18 \mathrm{PD}$ & $\begin{array}{l}\text { Inc: PD, Epworth scale } \\
\geq 8 \\
\text { Exc: H\&Y } 3\end{array}$ & $\begin{array}{l}\text { Determine the effect of } \\
\text { mild versus severe PD } \\
\text { on sleep parameters }\end{array}$ & PSG & $\begin{array}{l}\text { There was no significant difference in } \\
\text { objective sleep parameters between the } \\
\text { two groups. }\end{array}$ & Fair \\
\hline $\begin{array}{l}1 \\
1\end{array}$ & Comella 1993 & $\begin{array}{l}\text { Cross- } \\
\text { sectional }\end{array}$ & $10 \mathrm{PD}$ & $\begin{array}{l}\text { Inc: L-dopa + dopamine } \\
\text { agonist for } \geq 6 \text { months } \\
\text { Exc: dementia, } \\
\text { depression, serious } \\
\text { illness }\end{array}$ & $\begin{array}{l}\text { Compare PSG in PD } \\
\text { with and without } \\
\text { hallucinations }\end{array}$ & PSG & $\begin{array}{l}\text { The hallucinator group had a lower } \\
\text { sleep efficiency, a reduced total REM } \\
\text { sleep time, and a reduced REM } \\
\text { percentage }\end{array}$ & Fair \\
\hline $\begin{array}{l}12 \\
13 \\
14 \\
15\end{array}$ & $\begin{array}{l}\text { Perez-lloret } \\
2009\end{array}$ & $\begin{array}{l}\text { Cross- } \\
\text { sectional }\end{array}$ & $\begin{array}{l}71 \mathrm{PD} \\
21 \mathrm{HC}\end{array}$ & $\begin{array}{l}\text { Inc: PD, MMSE }>24 \\
\text { Exc: } N / R\end{array}$ & $\begin{array}{l}\text { Correlate sleep logs } \\
\text { compared to PD Sleep } \\
\text { Scale }\end{array}$ & Actigraphy & $\begin{array}{l}\text { Retrospective sleep quality evaluation } \\
\text { by the PDSS and day-to-day evaluation } \\
\text { by sleep log coincided }\end{array}$ & Poor \\
\hline $\begin{array}{l}1 \\
1 \\
1 \\
2 \\
2 \\
2\end{array}$ & Norlinah 2009 & $\begin{array}{l}\text { Cross- } \\
\text { sectional }\end{array}$ & $51 \mathrm{PD}$ & $\begin{array}{l}\text { Inc: PD } \\
\text { Exc: active psychiatric } \\
\text { condition, } \\
\text { benzodiazepine, } \\
\text { sedative or excessive } \\
\text { alcohol use }\end{array}$ & $\begin{array}{l}\text { Determine the } \\
\text { prevalence of sleep } \\
\text { disorders in PD }\end{array}$ & PSG & $\begin{array}{l}\text { The prevalence of PSG-quantified sleep } \\
\text { disturbances is high. Sleep } \\
\text { fragmentation is the most common }\end{array}$ & Poor \\
\hline 23 & Moller 2009 & Case-control & $\begin{array}{l}14 \mathrm{PD} \\
\text { w\&w/o } \\
\text { sleep attack }\end{array}$ & $\begin{array}{l}\text { Inc: PD, sudden sleep } \\
\text { onset } \\
\text { Exc: N/R }\end{array}$ & $\begin{array}{l}\text { Characterize and } \\
\text { analyze sleep attack } \\
\text { patterns on EEG }\end{array}$ & EEG & $\begin{array}{l}\text { Sleep attacks are characterized by } \\
\text { NREM stage } 1 \text { and } 2 \text { sleep in daytime } \\
\text { EEG }\end{array}$ & Poor \\
\hline $\begin{array}{l}21 \\
28 \\
29 \\
30 \\
31\end{array}$ & $\begin{array}{l}\text { Diederich } \\
2009\end{array}$ & $\begin{array}{l}\text { Cross- } \\
\text { sectional }\end{array}$ & $62 \mathrm{PD}$ & $\begin{array}{l}\text { Inc: PD, sleep } \\
\text { complaints } \\
\text { Exc: Dementia }\end{array}$ & $\begin{array}{l}\text { Examine the influence } \\
\text { of diurnal } \\
\text { dopaminergic } \\
\text { medication on sleep }\end{array}$ & PSG & $\begin{array}{l}\text { No impact of diurnal dopaminergic } \\
\text { medication on nocturnal slow-wave } \\
\text { sleep in PD patients }\end{array}$ & Poor \\
\hline 33 & Uemura 2009 & $\begin{array}{l}\text { Cross- } \\
\text { sectional }\end{array}$ & $\begin{array}{l}79 \mathrm{PD} \\
79 \mathrm{HC}\end{array}$ & $\begin{array}{l}\text { Inc: PD } \\
\text { Exc: atypical } \\
\text { parkinsonism }\end{array}$ & $\begin{array}{l}\text { Examine the relation } \\
\text { between the PD sleep } \\
\text { scale and PSG }\end{array}$ & PSG & $\begin{array}{l}\text { PD sleep scale had significant } \\
\text { correlation with PSG-measured sleep } \\
\text { efficiency. }\end{array}$ & Poor \\
\hline $\begin{array}{l}36 \\
37 \\
38 \\
39\end{array}$ & Roth 2003 & Case-control & $\begin{array}{l}16 \mathrm{PD} \\
\mathrm{w} \& \mathrm{w} / \mathrm{o} \\
\text { sleep } \\
\text { episodes }\end{array}$ & $\begin{array}{l}\text { Inc: } H \& Y 1 \text { to } 3 \text {, use of } \\
\text { dopamine agonists } \\
\text { Exc: serious } \\
\text { comorbidities }\end{array}$ & $\begin{array}{l}\text { Determine the } \\
\text { association of } \\
\text { dopamine agonists, } \\
\text { daytime sleepiness, and } \\
\text { sleep episodes }\end{array}$ & $\overline{P S G}$ & $\begin{array}{l}\text { Sleep episodes are related with } \\
\text { excessive daytime sleepiness and } \\
\text { unrelated to nocturnal sleep or use of } \\
\text { any specific dopamine agonist }\end{array}$ & Poor \\
\hline
\end{tabular}


PD, Parkinson's disease; HC, Healthy control; Inc, Inclusion; Exc, Exclusion; w\&w/o, with and without; N/R, non-reported; PSG, Polysomnography; REM, Rapid eye movement; DBS, Deep brain stimulation; STN, Subthalamic nucleus; EEG, electroencephalography; RBD, REM-sleep behavior disorder; H\&Y, Hoehn \& Yahr; MMSE, Mini-Mental State Examination 


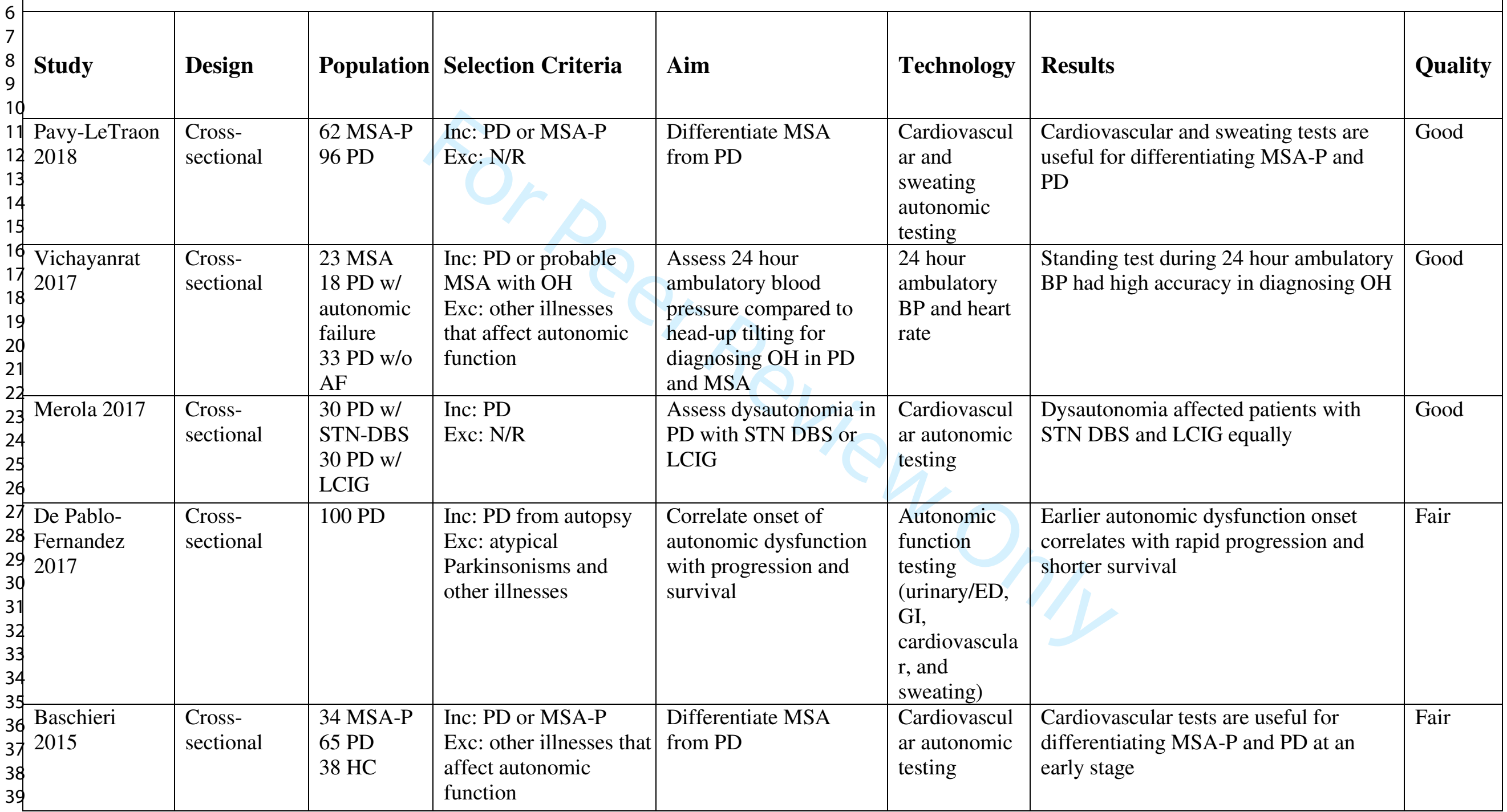


1

\begin{tabular}{|c|c|c|c|c|c|c|c|c|}
\hline $\begin{array}{l}2 \\
3 \\
4 \\
5\end{array}$ & $\begin{array}{l}\text { Haapaniemi } \\
2001\end{array}$ & \begin{tabular}{|l|} 
Cross- \\
sectional
\end{tabular} & $\begin{array}{l}54 \mathrm{PD} \\
47 \mathrm{HC}\end{array}$ & $\begin{array}{l}\text { Inc: treatment-naïve PD } \\
\text { Exc: autonomic } \\
\text { dysfunction }\end{array}$ & $\begin{array}{l}\text { Examine autonomic } \\
\text { cardiovascular } \\
\text { regulation in untreated } \\
\text { PD }\end{array}$ & $\begin{array}{l}\text { 24-hour ECG } \\
\text { monitoring }\end{array}$ & $\begin{array}{l}\text { Patients with mild hypokinesia had } \\
\text { higher heart frequency than patients } \\
\text { with more severe hypokinesia. }\end{array}$ & Fair \\
\hline $\begin{array}{l}6 \\
7 \\
8 \\
9 \\
10\end{array}$ & Tanaka 2000 & $\begin{array}{l}\text { Cross- } \\
\text { sectional }\end{array}$ & $\begin{array}{l}29 \mathrm{PD} \\
11 \mathrm{HC}\end{array}$ & $\begin{array}{l}\text { Inc: PD } \\
\text { Exc: atypical } \\
\text { parkinsonism, } \\
\text { depression }\end{array}$ & $\begin{array}{l}\text { Compare the P3 and N1 } \\
\text { amplitude between } \\
\text { demented, non- } \\
\text { demented PD, and HC }\end{array}$ & EEG & $\begin{array}{l}\text { There was an increased P3 amplitude } \\
\text { and EEG power in non-demented PD } \\
\text { patients versus controls }\end{array}$ & Fair \\
\hline $\begin{array}{l}11 \\
12 \\
13 \\
14 \\
15 \\
16\end{array}$ & Oka 1997 & $\begin{array}{l}\text { Cross- } \\
\text { sectional }\end{array}$ & $\begin{array}{l}30 \mathrm{PD} \\
30 \mathrm{HC}\end{array}$ & $\begin{array}{l}\text { Inc: PD, H\&Y } 1 \text { to } 4 \\
\text { Exc: atypical } \\
\text { parkinsonism, } \\
\text { antiparkinsonian drugs } \\
\text { other than L- } \\
\text { dopa/carbidopa }\end{array}$ & $\begin{array}{l}\text { Evaluation of QTc } \\
\text { interval in patients with } \\
\text { PD versus HC }\end{array}$ & ECG & $\begin{array}{l}\text { QTc intervals in PD significantly longer } \\
\text { than in HC. Unrelated to administration } \\
\text { of levodopa }\end{array}$ & Fair \\
\hline $\begin{array}{l}17 \\
18 \\
19 \\
20 \\
21\end{array}$ & Oka 2003 & $\begin{array}{l}\text { Cross- } \\
\text { sectional }\end{array}$ & $\begin{array}{l}20 \mathrm{PD} \\
50 \mathrm{HC}\end{array}$ & $\begin{array}{l}\text { Inc: } N / R \\
\text { Exc: } N / R\end{array}$ & $\begin{array}{l}\text { Evaluation of R-R } \\
\text { interval and BP during } \\
\text { Valsava maneuver and } \\
\text { deep inspiration }\end{array}$ & $\begin{array}{l}\text { ECG, } \\
\text { continuous } \\
\text { BP } \\
\text { monitoring }\end{array}$ & $\begin{array}{l}\text { Baroreflex sensitivity in PD is smaller } \\
\text { than in HC }\end{array}$ & Poor \\
\hline $\begin{array}{l}22 \\
23 \\
24 \\
25\end{array}$ & $\begin{array}{l}\text { Mastrocola } \\
1999\end{array}$ & $\begin{array}{l}\text { Cross- } \\
\text { sectional }\end{array}$ & $\begin{array}{l}13 \mathrm{PD} \\
13 \mathrm{HC}\end{array}$ & $\begin{array}{l}\text { Inc: PD } \\
\text { Exc: DM, HTN, drugs } \\
\text { affecting autonomic } \\
\text { tone }\end{array}$ & $\begin{array}{l}\text { Evaluate autonomic } \\
\text { dysfunction in PD }\end{array}$ & $\begin{array}{l}\text { 24-hour ECG } \\
\text { monitoring }\end{array}$ & $\begin{array}{l}\text { Significant difference in ECG } \\
\text { parameters between PD and } \mathrm{HC} \text {, } \\
\text { reflecting a reduction in autonomic } \\
\text { function. }\end{array}$ & Poor \\
\hline
\end{tabular}

PD, Parkinson's disease; HC, Healthy control; Inc, Inclusion; Exc, Exclusion; w\&w/o, with and without; N/R, non-reported; min, minutes; PDD,

Parkinson's disease dementia; DBS, Deep brain stimulation; STN, Subthalamic nucleus; EEG, electroencephalography; ECG, Electrocardiography; DM,

Diabetes mellitus; HTN, Hypertension; LCIG, levodopa-carbidopa infusion gel; MSA and MSA-P, Multiple System Atropy - Parkinsonism; OH,

orthostatic hypotension; BP, blood pressure; H\&Y, Hoehn and Yahr 
Table e-1: Database search methods

\begin{tabular}{|c|}
\hline$d$ \\
\hline Search term (filter humans, English) \\
\hline 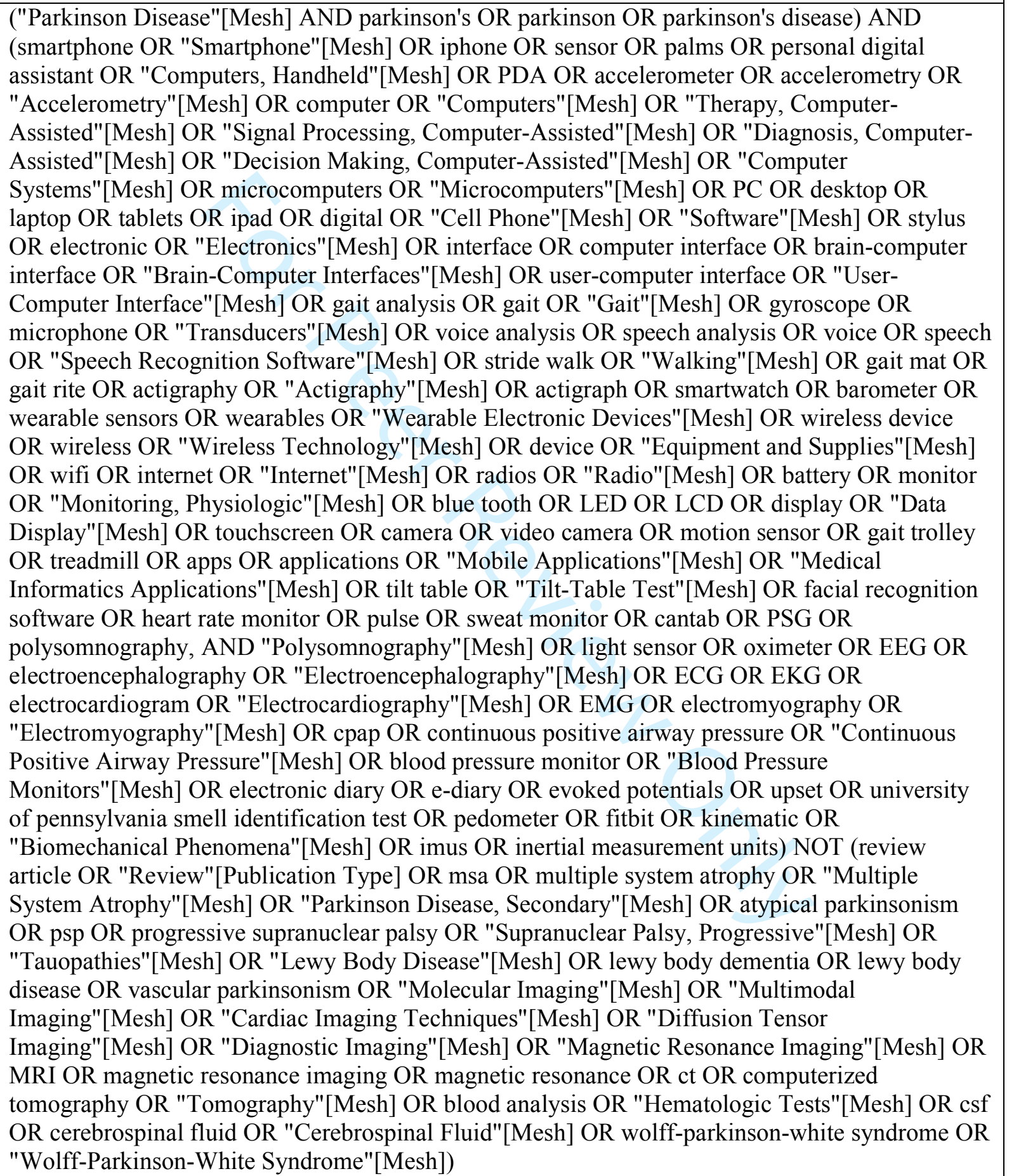 \\
\hline
\end{tabular}




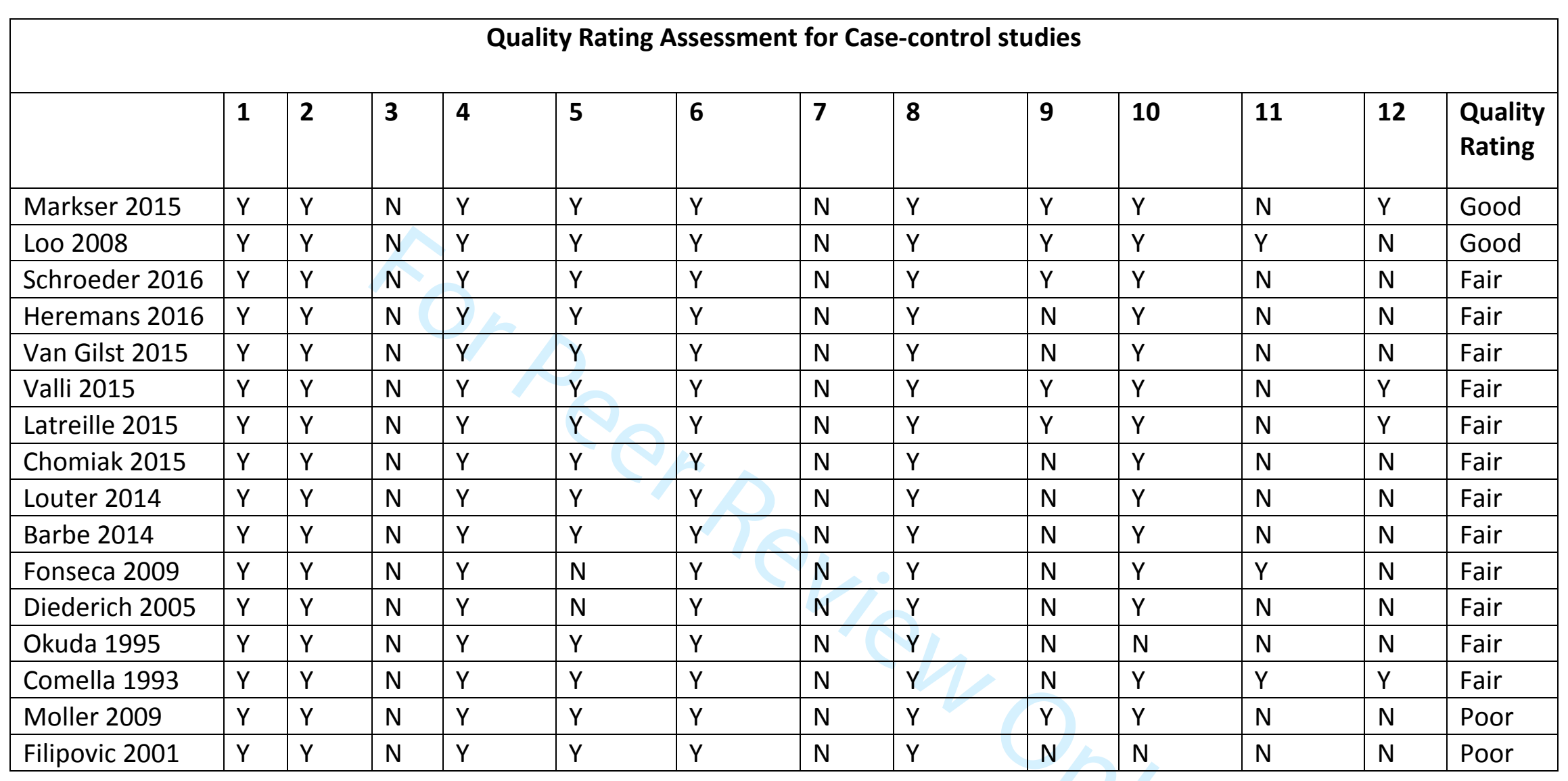

\section{Questions:}

1. Was the research question or objective in this paper clearly stated and appropriate?

2. Was the study population clearly specified and defined?

3. Did the authors include a sample size justification?

4. Were controls selected or recruited from the same or similar population that gave rise to the cases (including the same timeframe)?

5. Were the definitions, inclusion and exclusion criteria, algorithms or processes used to identify or select cases and controls valid, reliable, and implemented consistently across all study participants? 
6. Were the cases clearly defined and differentiated from controls?

7. If less than 100 percent of eligible cases and/or controls were selected for the study, were the cases and/or controls randomly selected from those eligible?

8. Was there use of concurrent controls?

9. Were the investigators able to confirm that the exposure/risk occurred prior to the development of the condition or event that defined a participant as a case?

10. Were the measures of exposure/risk clearly defined, valid, reliable, and implemented consistently (including the same time period) across all study participants?

11. Were the assessors of exposure/risk blinded to the case or control status of participants?

12. Were key potential confounding variables measured and adjusted statistically in the analyses? If matching was used, did the investigators account for matching during study analysis? 


\begin{tabular}{|c|c|c|c|c|c|c|c|c|c|c|c|c|c|c|c|}
\hline \multicolumn{16}{|c|}{ Quality Rating Assessment - Observational cohort and cross-sectional studies } \\
\hline & 1 & 2 & 3 & 4 & 5 & 6 & 7 & 8 & 9 & 10 & 11 & 12 & 13 & 14 & $\begin{array}{l}\text { Quality } \\
\text { Rating }\end{array}$ \\
\hline $\begin{array}{l}\text { Pavy-LeTraon } \\
2018\end{array}$ & $\mathrm{Y}$ & Y & $\mathrm{N}$ & Y & $\mathrm{N}$ & Y & Y & $\mathrm{N}$ & $\mathrm{N}$ & $\mathrm{Y}$ & $\mathrm{Y}$ & $\mathrm{N}$ & $\mathrm{Y}$ & $\mathrm{Y}$ & Good \\
\hline Rabelo 2017 & $\mathrm{Y}$ & $\mathrm{Y}$ & $\mathrm{N}$ & $\mathrm{Y}$ & $\mathrm{N}$ & $\mathrm{Y}$ & $\mathrm{Y}$ & $\mathrm{N}$ & $\mathrm{Y}$ & $\mathrm{N}$ & $\mathrm{Y}$ & $\mathrm{N}$ & $\mathrm{Y}$ & $\mathrm{N}$ & Good \\
\hline Schlachetzki 2017 & $\mathrm{Y}$ & $\mathrm{Y}$ & $\mathrm{N}$ & $\mathrm{Y}$ & $\mathrm{N}$ & $\mathrm{Y}$ & $\mathrm{Y}$ & $\mathrm{N}$ & $\mathrm{Y}$ & $\mathrm{N}$ & $\mathrm{Y}$ & $\mathrm{N}$ & $\mathrm{Y}$ & $\mathrm{N}$ & Good \\
\hline Son 2017 & $\mathrm{Y}$ & $\mathrm{Y}$ & $\mathrm{N}$ & $\mathrm{Y}$ & $\mathrm{N}$ & $\mathrm{Y}$ & Y & $\mathrm{N}$ & $\mathrm{Y}$ & $\mathrm{N}$ & $\mathrm{Y}$ & $\mathrm{N}$ & $Y$ & $\mathrm{~N}$ & Good \\
\hline Conradsson 2017 & $\mathrm{Y}$ & $\mathrm{Y}$ & $\mathrm{N}$ & $\mathrm{Y}$ & $\mathrm{Y}$ & $\mathrm{Y}$ & $\mathrm{Y}$ & $\mathrm{N}$ & $\mathrm{Y}$ & $\mathrm{N}$ & $\mathrm{Y}$ & $\mathrm{N}$ & $\mathrm{Y}$ & $\mathrm{N}$ & Good \\
\hline Vichayanrat 2017 & $\mathrm{Y}$ & $\mathrm{Y}$ & $\mathrm{N}$ & $\mathrm{Y}$ & $\mathrm{N}$ & $\mathrm{Y}$ & $\mathrm{Y}$ & $\mathrm{Y}$ & $\mathrm{Y}$ & $\mathrm{Y}$ & $\mathrm{Y}$ & $\mathrm{N}$ & $\mathrm{Y}$ & $\mathrm{Y}$ & Good \\
\hline Merola 2017 & $\mathrm{Y}$ & $\mathrm{Y}$ & $\mathrm{N}$ & $\mathrm{Y}$ & $\mathrm{Y}$ & $\mathrm{Y}$ & $\mathrm{Y}$ & $\mathrm{N}$ & $\mathrm{Y}$ & $\mathrm{N}$ & $\mathrm{Y}$ & $\mathrm{Y}$ & $\mathrm{Y}$ & $\mathrm{Y}$ & Good \\
\hline $\begin{array}{l}\text { Godino-Llorente } \\
2017\end{array}$ & $\mathrm{Y}$ & $\mathrm{Y}$ & $\mathrm{N}$ & $\mathrm{Y}$ & $\mathrm{N}$ & $\mathrm{Y}$ & $\mathrm{Y}$ & $\mathrm{N}$ & $\mathrm{Y}$ & $\mathrm{N}$ & $\mathrm{Y}$ & $\mathrm{N}$ & $\mathrm{Y}$ & $\mathrm{N}$ & Good \\
\hline Vaiciukynas 2017 & $\mathrm{Y}$ & $\mathrm{Y}$ & $\mathrm{N}$ & $\mathrm{Y}$ & $\mathrm{N}$ & $\mathrm{Y}$ & $\mathrm{Y}$ & $\mathrm{N}$ & $\mathrm{Y}$ & $\mathrm{N}$ & $\mathrm{Y}$ & $\mathrm{N}$ & $\mathrm{Y}$ & $\mathrm{N}$ & Good \\
\hline Pham 2017 & $\mathrm{Y}$ & $\mathrm{Y}$ & $\mathrm{N}$ & $\mathrm{Y}$ & $\mathrm{N}$ & $\mathrm{Y}$ & $\mathrm{Y}$ & $\mathrm{N}$ & $\mathrm{Y}$ & $\mathrm{N}$ & $\mathrm{Y}$ & $\mathrm{N}$ & $\mathrm{Y}$ & $\mathrm{Y}$ & Good \\
\hline Bologna 2016 & $\mathrm{Y}$ & $\mathrm{Y}$ & $\mathrm{N}$ & $\mathrm{Y}$ & $\mathrm{N}$ & $\mathrm{Y}$ & $\mathrm{Y}$ & $\mathrm{N}$ & $\mathrm{Y}$ & $\mathrm{N}$ & $\mathrm{Y}$ & $\mathrm{Y}$ & $\mathrm{Y}$ & $\mathrm{Y}$ & Good \\
\hline Pasluosta 2015 & $\mathrm{Y}$ & $\mathrm{Y}$ & $\mathrm{N}$ & $\mathrm{Y}$ & $\mathrm{N}$ & $\mathrm{Y}$ & $\mathrm{Y}$ & $\mathrm{Y}$ & $\mathrm{Y}$ & $\mathrm{N}$ & $\mathrm{Y}$ & $\mathrm{N}$ & $\mathrm{Y}$ & $\mathrm{Y}$ & Good \\
\hline Ricciardi 2015 & $\mathrm{Y}$ & $\mathrm{Y}$ & $\mathrm{N}$ & $\mathrm{Y}$ & $\mathrm{N}$ & $\mathrm{Y}$ & $\mathrm{Y}$ & $\mathrm{N}$ & $\mathrm{Y}$ & $\mathrm{N}$ & $\mathrm{Y}$ & $\mathrm{Y}$ & $\mathrm{Y}$ & $\mathrm{Y}$ & Good \\
\hline Arora 2015 & $\mathrm{Y}$ & $\mathrm{Y}$ & $\mathrm{N}$ & $\mathrm{Y}$ & $\mathrm{N}$ & $\mathrm{Y}$ & $\mathrm{Y}$ & $\mathrm{N}$ & $\mathrm{Y}$ & $\mathrm{N}$ & $\mathrm{Y}$ & $\mathrm{N}$ & $\mathrm{Y}$ & $\mathrm{N}$ & Good \\
\hline Muller 2010 & $\mathrm{Y}$ & $\mathrm{Y}$ & $\mathrm{N}$ & $\mathrm{Y}$ & $\mathrm{N}$ & $\mathrm{Y}$ & $\mathrm{Y}$ & $\mathrm{N}$ & $\mathrm{Y}$ & $\mathrm{N}$ & $\mathrm{Y}$ & $\mathrm{N}$ & $\mathrm{Y}$ & $\mathrm{N}$ & Good \\
\hline Rand 2010 & $\mathrm{Y}$ & $\mathrm{Y}$ & $\mathrm{N}$ & $\mathrm{Y}$ & $\mathrm{N}$ & $\mathrm{Y}$ & $\mathrm{Y}$ & $\mathrm{N}$ & $\mathrm{Y}$ & $\mathrm{N}$ & $\mathrm{Y}$ & $\mathrm{N}$ & $\mathrm{Y}$ & $\mathrm{N}$ & Good \\
\hline Cho 2009 & $\mathrm{Y}$ & $\mathrm{Y}$ & $\mathrm{N}$ & $\mathrm{Y}$ & $\mathrm{N}$ & $\mathrm{Y}$ & $\mathrm{Y}$ & $\mathrm{N}$ & $\mathrm{Y}$ & $\mathrm{N}$ & $\mathrm{Y}$ & $\mathrm{N}$ & $\mathrm{Y}$ & $\mathrm{N}$ & Good \\
\hline Nojszewska 2009 & $\mathrm{Y}$ & $\mathrm{Y}$ & $\mathrm{N}$ & $\mathrm{Y}$ & $\mathrm{N}$ & $\mathrm{Y}$ & $\mathrm{Y}$ & $\mathrm{Y}$ & $\mathrm{Y}$ & $\mathrm{N}$ & $\mathrm{Y}$ & $\mathrm{N}$ & $\mathrm{Y}$ & $\mathrm{N}$ & Good \\
\hline Švehlík 2009 & $\mathrm{Y}$ & $\mathrm{Y}$ & $\mathrm{N}$ & $\mathrm{Y}$ & $\mathrm{N}$ & $\mathrm{Y}$ & $\mathrm{Y}$ & $\mathrm{N}$ & $\mathrm{Y}$ & $\mathrm{N}$ & $\mathrm{Y}$ & $\mathrm{N}$ & $\mathrm{Y}$ & $\mathrm{N}$ & Good \\
\hline Mcvey 2009 & $\mathrm{Y}$ & $\mathrm{Y}$ & $\mathrm{N}$ & $\mathrm{Y}$ & $\mathrm{N}$ & $\mathrm{Y}$ & $\mathrm{Y}$ & $\mathrm{N}$ & $\mathrm{Y}$ & $\mathrm{N}$ & $\mathrm{Y}$ & $\mathrm{N}$ & $\mathrm{Y}$ & $\mathrm{N}$ & Good \\
\hline Kim 2009 & $\mathrm{Y}$ & $\mathrm{Y}$ & $\mathrm{N}$ & $\mathrm{N}$ & $\mathrm{N}$ & $\mathrm{Y}$ & $\mathrm{Y}$ & $\mathrm{Y}$ & $\mathrm{Y}$ & $\mathrm{N}$ & $\mathrm{Y}$ & $\mathrm{N}$ & $\mathrm{Y}$ & $\mathrm{N}$ & Good \\
\hline Espay 2009 & $\mathrm{Y}$ & $\mathrm{Y}$ & $\mathrm{N}$ & $\mathrm{Y}$ & $\mathrm{N}$ & $Y$ & $\mathrm{Y}$ & $\mathrm{N}$ & $\mathrm{Y}$ & $\mathrm{N}$ & $\mathrm{Y}$ & $\mathrm{N}$ & $\mathrm{Y}$ & $\mathrm{N}$ & Good \\
\hline Alice 2007 & $\mathrm{Y}$ & $\mathrm{Y}$ & $\mathrm{N}$ & $Y$ & $\mathrm{~N}$ & $\mathrm{Y}$ & $\mathrm{Y}$ & $\mathrm{N}$ & $\mathrm{Y}$ & $\mathrm{N}$ & $\mathrm{Y}$ & $\mathrm{N}$ & $\mathrm{Y}$ & $\mathrm{N}$ & Good \\
\hline Mak 2007 & $\mathrm{Y}$ & $\mathrm{Y}$ & $\mathrm{N}$ & $\mathrm{Y}$ & $\mathrm{N}$ & $\mathrm{Y}$ & $\mathrm{Y}$ & $\mathrm{N}$ & $\mathrm{Y}$ & $\mathrm{N}$ & $\mathrm{Y}$ & $\mathrm{N}$ & $\mathrm{Y}$ & $\mathrm{N}$ & Good \\
\hline Hong 2007 & $\mathrm{Y}$ & $\mathrm{Y}$ & $\mathrm{N}$ & $\mathrm{Y}$ & $\mathrm{N}$ & $\mathrm{Y}$ & $\mathrm{Y}$ & $\mathrm{N}$ & $\mathrm{Y}$ & $\mathrm{N}$ & $\mathrm{Y}$ & $\mathrm{N}$ & $\mathrm{Y}$ & $\mathrm{N}$ & Good \\
\hline Ferrarin 2005 & $\mathrm{Y}$ & $\mathrm{Y}$ & $\mathrm{N}$ & $\mathrm{Y}$ & $\mathrm{N}$ & $\mathrm{Y}$ & $\mathrm{Y}$ & $\mathrm{Y}$ & $\mathrm{Y}$ & $\mathrm{Y}$ & $\mathrm{Y}$ & $\mathrm{Y}$ & $\mathrm{Y}$ & $\mathrm{Y}$ & Good \\
\hline Stolze 2001 & $\mathrm{Y}$ & $\mathrm{Y}$ & $\mathrm{Y}$ & $\mathrm{Y}$ & $\mathrm{N}$ & $Y$ & $\mathrm{Y}$ & $\mathrm{N}$ & $\mathrm{Y}$ & $\mathrm{N}$ & $\mathrm{Y}$ & $\mathrm{N}$ & $\mathrm{Y}$ & $\mathrm{Y}$ & Good \\
\hline
\end{tabular}




\begin{tabular}{|c|c|c|c|c|c|c|c|c|c|c|c|c|c|c|c|}
\hline Castiello 2000 & $\mathrm{Y}$ & $\mathrm{Y}$ & $\mathrm{N}$ & $\mathrm{Y}$ & $\mathrm{N}$ & $\mathrm{Y}$ & $\mathrm{Y}$ & $\mathrm{Y}$ & $\mathrm{Y}$ & $\mathrm{N}$ & $\mathrm{Y}$ & $\mathrm{N}$ & $\mathrm{Y}$ & $\mathrm{Y}$ & Good \\
\hline Lin 2018 & $\mathrm{Y}$ & $\mathrm{N}$ & $\mathrm{N}$ & $\mathrm{N}$ & $\mathrm{N}$ & $\mathrm{Y}$ & $\mathrm{Y}$ & $\mathrm{N}$ & $\mathrm{Y}$ & $\mathrm{N}$ & $\mathrm{Y}$ & $\mathrm{Y}$ & $\mathrm{Y}$ & $\mathrm{N}$ & Fair \\
\hline Tanaka 2018 & $\mathrm{Y}$ & $\mathrm{Y}$ & $\mathrm{N}$ & $\mathrm{Y}$ & $\mathrm{N}$ & $\mathrm{Y}$ & $\mathrm{Y}$ & $\mathrm{N}$ & $\mathrm{Y}$ & $\mathrm{N}$ & $\mathrm{Y}$ & $\mathrm{N}$ & $\mathrm{Y}$ & $\mathrm{N}$ & Fair \\
\hline Summa 2017 & $\mathrm{Y}$ & Y & $\mathrm{N}$ & $\mathrm{Y}$ & $\mathrm{N}$ & $\mathrm{Y}$ & $\mathrm{Y}$ & $\mathrm{N}$ & $\mathrm{Y}$ & $\mathrm{N}$ & $\mathrm{Y}$ & $\mathrm{N}$ & Y & $\mathrm{N}$ & Fair \\
\hline Zibetti 2017 & $\mathrm{Y}$ & $\mathrm{Y}$ & $\mathrm{N}$ & $\mathrm{Y}$ & $\mathrm{N}$ & $\mathrm{Y}$ & $\mathrm{Y}$ & $\mathrm{N}$ & $\mathrm{Y}$ & $\mathrm{Y}$ & $\mathrm{Y}$ & $\mathrm{N}$ & $\mathrm{Y}$ & $\mathrm{N}$ & Fair \\
\hline Jeon 2017 & $\mathrm{Y}$ & $\mathrm{Y}$ & $\mathrm{N}$ & $\mathrm{Y}$ & $\mathrm{N}$ & $\mathrm{Y}$ & $\mathrm{Y}$ & $\mathrm{N}$ & $\mathrm{Y}$ & $\mathrm{N}$ & $\mathrm{Y}$ & $\mathrm{N}$ & $\mathrm{Y}$ & $\mathrm{N}$ & Fair \\
\hline $\begin{array}{l}\text { De Pablo- } \\
\text { Fernandez } 2017\end{array}$ & $\mathrm{Y}$ & $\mathrm{Y}$ & $\mathrm{N}$ & $\mathrm{Y}$ & $\mathrm{N}$ & $\mathrm{Y}$ & $\mathrm{Y}$ & $\mathrm{N}$ & $\mathrm{Y}$ & $\mathrm{N}$ & $\mathrm{Y}$ & $\mathrm{Y}$ & $\mathrm{Y}$ & $\mathrm{N}$ & Fair \\
\hline Gauvin 2017 & $\mathrm{Y}$ & $\mathrm{Y}$ & $\mathrm{N}$ & $\mathrm{Y}$ & $\mathrm{N}$ & $\mathrm{Y}$ & $\mathrm{Y}$ & $\mathrm{N}$ & $\mathrm{Y}$ & $\mathrm{N}$ & $\mathrm{Y}$ & $\mathrm{N}$ & $\mathrm{Y}$ & $\mathrm{N}$ & Fair \\
\hline Latreille 2016 & $\mathrm{Y}$ & $\mathrm{Y}$ & $\mathrm{N}$ & $\mathrm{Y}$ & $\mathrm{N}$ & $\mathrm{Y}$ & $\mathrm{Y}$ & $\mathrm{N}$ & $\mathrm{Y}$ & $\mathrm{N}$ & $\mathrm{Y}$ & $\mathrm{N}$ & $\mathrm{Y}$ & $\mathrm{N}$ & Fair \\
\hline Heremans 2016 & $\mathrm{Y}$ & $\mathrm{Y}$ & $\mathrm{N}$ & $\mathrm{Y}$ & $\mathrm{N}$ & $\mathrm{Y}$ & $\mathrm{Y}$ & $\mathrm{N}$ & $\mathrm{Y}$ & $\mathrm{N}$ & $\mathrm{Y}$ & $\mathrm{N}$ & $\mathrm{Y}$ & $\mathrm{N}$ & Fair \\
\hline Fraiwan 2016 & $\mathrm{Y}$ & $\mathrm{Y}$ & $\mathrm{N}$ & $\mathrm{N}$ & $\mathrm{N}$ & $\mathrm{Y}$ & $\mathrm{Y}$ & $\mathrm{N}$ & $\mathrm{N}$ & $\mathrm{N}$ & $\mathrm{Y}$ & $\mathrm{Y}$ & $\mathrm{Y}$ & $\mathrm{Y}$ & Fair \\
\hline Rektorova 2016 & $\mathrm{Y}$ & $\mathrm{Y}$ & $\mathrm{N}$ & $\mathrm{Y}$ & $\mathrm{N}$ & $\mathrm{Y}$ & $\mathrm{Y}$ & $\mathrm{N}$ & $\mathrm{Y}$ & $\mathrm{N}$ & $\mathrm{Y}$ & $\mathrm{N}$ & $\mathrm{Y}$ & $\mathrm{N}$ & Fair \\
\hline $\begin{array}{l}\text { Alatriste-Booth } \\
2015\end{array}$ & $\mathrm{Y}$ & $\mathrm{Y}$ & $\mathrm{N}$ & $\mathrm{N}$ & $\mathrm{N}$ & $\mathrm{Y}$ & $\mathrm{Y}$ & $\mathrm{N}$ & $\mathrm{Y}$ & $\mathrm{N}$ & $\mathrm{Y}$ & $\mathrm{N}$ & $\mathrm{Y}$ & $\mathrm{N}$ & Fair \\
\hline $\begin{array}{l}\text { Zimmermann } \\
2015\end{array}$ & $\mathrm{Y}$ & $\mathrm{Y}$ & $\mathrm{N}$ & $\mathrm{Y}$ & $\mathrm{N}$ & $\mathrm{Y}$ & $\mathrm{Y}$ & $\mathrm{N}$ & $\mathrm{Y}$ & $\mathrm{N}$ & $\mathrm{Y}$ & $\mathrm{N}$ & $\mathrm{Y}$ & $\mathrm{N}$ & Fair \\
\hline Parisi 2015 & $\mathrm{Y}$ & $\mathrm{Y}$ & $\mathrm{N}$ & $\mathrm{N}$ & $\mathrm{N}$ & $\mathrm{Y}$ & $\mathrm{Y}$ & $\mathrm{N}$ & $\mathrm{Y}$ & $\mathrm{N}$ & $\mathrm{Y}$ & $\mathrm{N}$ & $\mathrm{Y}$ & $\mathrm{N}$ & Fair \\
\hline $\begin{array}{l}\text { Thanawattano } \\
2015\end{array}$ & $\mathrm{Y}$ & $\mathrm{Y}$ & $\mathrm{N}$ & $\mathrm{N}$ & $\mathrm{N}$ & $\mathrm{Y}$ & $\mathrm{Y}$ & $\mathrm{N}$ & $\mathrm{Y}$ & $\mathrm{N}$ & $Y$ & $\mathrm{Y}$ & $\mathrm{Y}$ & $\mathrm{N}$ & Fair \\
\hline $\begin{array}{l}\text { Thanawattano } \\
2015\end{array}$ & $\mathrm{Y}$ & $\mathrm{Y}$ & $\mathrm{N}$ & $\mathrm{N}$ & $\mathrm{N}$ & $\mathrm{Y}$ & $\mathrm{Y}$ & $\mathrm{N}$ & $\mathrm{Y}$ & $\mathrm{N}$ & $\bar{Y}$ & $\mathrm{~N}$ & $\mathrm{Y}$ & $\mathrm{N}$ & Fair \\
\hline Baschieri 2015 & $\mathrm{Y}$ & $\mathrm{Y}$ & $\mathrm{N}$ & Y & $\mathrm{N}$ & $\mathrm{N}$ & $\mathrm{Y}$ & $\mathrm{N}$ & $\mathrm{Y}$ & $\mathrm{Y}$ & $Y$ & $\mathrm{Y}$ & $\mathrm{Y}$ & $\mathrm{N}$ & Fair \\
\hline Kotschet 2014 & $\mathrm{Y}$ & $\mathrm{Y}$ & $\mathrm{N}$ & $\mathrm{N}$ & $\mathrm{N}$ & $\mathrm{Y}$ & $\mathrm{Y}$ & $\mathrm{N}$ & $\mathrm{Y}$ & $\mathrm{N}$ & $\mathrm{Y}$ & $\mathrm{N}$ & $\mathrm{Y}$ & $\mathrm{N}$ & Fair \\
\hline Dillmann 2014 & $\mathrm{Y}$ & $\mathrm{N}$ & $\mathrm{N}$ & $\mathrm{Y}$ & $\mathrm{N}$ & $\mathrm{Y}$ & $\mathrm{Y}$ & $\mathrm{N}$ & $\mathrm{Y}$ & $\mathrm{N}$ & $Y$ & $\mathrm{~N}$ & $\mathrm{Y}$ & $\mathrm{N}$ & Fair \\
\hline $\begin{array}{l}\text { Cano-de-la- } \\
\text { Cuerda } 2014\end{array}$ & $\mathrm{Y}$ & $\mathrm{Y}$ & $\mathrm{N}$ & $\mathrm{Y}$ & $\mathrm{N}$ & $\mathrm{Y}$ & $\mathrm{Y}$ & $\mathrm{N}$ & $\mathrm{Y}$ & $\mathrm{N}$ & $\mathrm{Y}$ & $\mathrm{N}$ & $\mathrm{Y}$ & $\mathrm{N}$ & Fair \\
\hline Vaughan 2013 & $\mathrm{Y}$ & $\mathrm{Y}$ & $\mathrm{N}$ & $\mathrm{Y}$ & $\mathrm{N}$ & $\mathrm{Y}$ & $\mathrm{Y}$ & $\mathrm{N}$ & $\mathrm{Y}$ & $\mathrm{N}$ & $\mathrm{Y}$ & $\mathrm{N}$ & $\mathrm{Y}$ & $\mathrm{N}$ & Fair \\
\hline Moore 2013 & $\mathrm{Y}$ & $\mathrm{Y}$ & $\mathrm{N}$ & $\mathrm{Y}$ & $\mathrm{N}$ & $\mathrm{Y}$ & $\mathrm{Y}$ & $\mathrm{N}$ & $\mathrm{Y}$ & $\mathrm{N}$ & $\mathrm{Y}$ & $\mathrm{N}$ & $\mathrm{Y}$ & $\mathrm{N}$ & Fair \\
\hline $\begin{array}{l}\text { WS Coriolano } \\
2012\end{array}$ & $\mathrm{Y}$ & $\mathrm{Y}$ & $\mathrm{N}$ & $\mathrm{Y}$ & $\mathrm{N}$ & $\mathrm{Y}$ & $\mathrm{Y}$ & $\mathrm{N}$ & $\mathrm{Y}$ & $\mathrm{N}$ & $\bar{Y}$ & $\mathrm{~N}$ & $\mathrm{Y}$ & $\mathrm{N}$ & Fair \\
\hline Zampieri 2011 & $\mathrm{Y}$ & $\mathrm{Y}$ & $\mathrm{N}$ & $\mathrm{N}$ & $\mathrm{N}$ & $\mathrm{Y}$ & $\mathrm{Y}$ & $\mathrm{N}$ & $\mathrm{Y}$ & $\mathrm{N}$ & $\mathrm{Y}$ & $\mathrm{N}$ & $\mathrm{Y}$ & $\mathrm{N}$ & Fair \\
\hline Merello 2010 & $\mathrm{Y}$ & $\mathrm{Y}$ & $\mathrm{N}$ & $\mathrm{Y}$ & $\mathrm{N}$ & $\mathrm{Y}$ & $\mathrm{Y}$ & $\mathrm{Y}$ & $\mathrm{Y}$ & $\mathrm{N}$ & $\mathrm{Y}$ & $\mathrm{N}$ & $\mathrm{Y}$ & $\mathrm{N}$ & Fair \\
\hline
\end{tabular}




\begin{tabular}{|c|c|c|c|c|c|c|c|c|c|c|c|c|c|c|c|}
\hline Salarian 2010 & $\mathrm{Y}$ & $\mathrm{Y}$ & $\mathrm{N}$ & $\mathrm{Y}$ & $\mathrm{N}$ & $\mathrm{Y}$ & $\mathrm{Y}$ & $\mathrm{N}$ & $\mathrm{Y}$ & $\mathrm{N}$ & $\mathrm{Y}$ & $\mathrm{N}$ & $\mathrm{Y}$ & $\mathrm{N}$ & Fair \\
\hline Naismith 2010 & $\mathrm{Y}$ & $\mathrm{Y}$ & $\mathrm{N}$ & $\mathrm{N}$ & $\mathrm{N}$ & $\mathrm{Y}$ & $\mathrm{Y}$ & $\mathrm{N}$ & $\mathrm{Y}$ & $\mathrm{N}$ & $\mathrm{Y}$ & $\mathrm{N}$ & $\mathrm{Y}$ & $\mathrm{N}$ & Fair \\
\hline Ganesan 2010 & $\mathrm{Y}$ & $\mathrm{Y}$ & $\mathrm{N}$ & $\mathrm{Y}$ & $\mathrm{N}$ & $\mathrm{Y}$ & $\mathrm{Y}$ & $\mathrm{N}$ & $\mathrm{Y}$ & $\mathrm{N}$ & $\mathrm{Y}$ & $\mathrm{N}$ & $\mathrm{Y}$ & $\mathrm{N}$ & Fair \\
\hline Fischer 2010 & $\mathrm{Y}$ & Y & $\mathrm{N}$ & $\mathrm{Y}$ & $\mathrm{N}$ & $\mathrm{Y}$ & $\mathrm{Y}$ & $\mathrm{Y}$ & $\mathrm{Y}$ & $\mathrm{N}$ & Y & $\mathrm{N}$ & $\mathrm{Y}$ & $\mathrm{N}$ & Fair \\
\hline Johnsen 2010 & $\mathrm{Y}$ & $\mathrm{Y}$ & $\mathrm{Y}$ & $\mathrm{Y}$ & $\mathrm{N}$ & $\mathrm{Y}$ & $\mathrm{Y}$ & $\mathrm{N}$ & $\mathrm{Y}$ & $\mathrm{N}$ & $\mathrm{Y}$ & $\mathrm{Y}$ & $\mathrm{N}$ & $\mathrm{Y}$ & Fair \\
\hline Cantiniaux 2010 & $\mathrm{Y}$ & $\mathrm{Y}$ & $\mathrm{Y}$ & $\mathrm{Y}$ & $\mathrm{N}$ & $\mathrm{Y}$ & $\mathrm{Y}$ & $\mathrm{N}$ & $\mathrm{Y}$ & $\mathrm{N}$ & $\mathrm{Y}$ & $\mathrm{N}$ & $\mathrm{Y}$ & $\mathrm{Y}$ & Fair \\
\hline Mancini 2009 & $\mathrm{Y}$ & $\mathrm{Y}$ & $\mathrm{N}$ & $\mathrm{Y}$ & $\mathrm{N}$ & $\bar{Y}$ & $\mathrm{Y}$ & $\mathrm{N}$ & $\mathrm{Y}$ & $\mathrm{N}$ & $\mathrm{Y}$ & $\mathrm{N}$ & $\mathrm{Y}$ & $\mathrm{N}$ & Fair \\
\hline Hong 2009 & $\mathrm{Y}$ & $\mathrm{Y}$ & $\mathrm{N}$ & $\mathrm{N}$ & $\mathrm{N}$ & $\mathrm{Y}$ & $\mathrm{Y}$ & $\mathrm{N}$ & $\mathrm{Y}$ & $\mathrm{N}$ & $\mathrm{Y}$ & $\mathrm{N}$ & $\mathrm{Y}$ & $\mathrm{N}$ & Fair \\
\hline Stack 2008 & $\mathrm{Y}$ & $\mathrm{Y}$ & $\mathrm{N}$ & $\mathrm{Y}$ & $\mathrm{N}$ & $\mathrm{Y}$ & $\mathrm{Y}$ & $\mathrm{N}$ & $\mathrm{Y}$ & $\mathrm{N}$ & $\mathrm{Y}$ & $\mathrm{N}$ & $\mathrm{Y}$ & $\mathrm{N}$ & Fair \\
\hline Huxham 2008 & $\mathrm{Y}$ & $\mathrm{Y}$ & $\mathrm{N}$ & $\mathrm{Y}$ & $\mathrm{N}$ & $\mathrm{Y}$ & $\mathrm{Y}$ & $\mathrm{N}$ & $\mathrm{Y}$ & $\mathrm{N}$ & $\mathrm{Y}$ & $\mathrm{N}$ & $\mathrm{Y}$ & $\mathrm{N}$ & Fair \\
\hline Carpinella 2007 & $\mathrm{Y}$ & $\mathrm{Y}$ & $\mathrm{N}$ & $\mathrm{N}$ & $\mathrm{N}$ & $\mathrm{Y}$ & $\mathrm{Y}$ & $\mathrm{N}$ & $\mathrm{Y}$ & $\mathrm{N}$ & $\mathrm{Y}$ & $\mathrm{N}$ & $\mathrm{Y}$ & $\mathrm{N}$ & Fair \\
\hline Matsui 2007 & $\mathrm{Y}$ & $\mathrm{Y}$ & $\mathrm{N}$ & $\mathrm{Y}$ & $\mathrm{N}$ & $\mathrm{Y}$ & $\mathrm{Y}$ & $\mathrm{N}$ & $\mathrm{Y}$ & $\mathrm{N}$ & $\mathrm{Y}$ & $\mathrm{N}$ & $\mathrm{Y}$ & $\mathrm{N}$ & Fair \\
\hline Shpirer 2006 & $\mathrm{Y}$ & $\mathrm{Y}$ & $\mathrm{N}$ & $\mathrm{Y}$ & $\mathrm{N}$ & $\mathrm{Y}$ & $Y$ & $\mathrm{~N}$ & $\mathrm{Y}$ & $Y$ & $\mathrm{Y}$ & $\mathrm{N}$ & $\mathrm{Y}$ & $\mathrm{N}$ & Fair \\
\hline Dhawan 2006 & $\mathrm{Y}$ & $\mathrm{Y}$ & $\mathrm{N}$ & $\mathrm{Y}$ & $\mathrm{N}$ & $Y$ & $\mathrm{Y}$ & $\mathrm{N}$ & $\mathrm{Y}$ & $\mathrm{N}$ & $\mathrm{Y}$ & $\mathrm{N}$ & $\mathrm{Y}$ & $\mathrm{N}$ & Fair \\
\hline Jobbagy 2004 & $\mathrm{Y}$ & $\mathrm{Y}$ & $\mathrm{N}$ & $\mathrm{N}$ & $\mathrm{N}$ & $\mathrm{Y}$ & $\mathrm{Y}$ & $\mathrm{N}$ & $\mathrm{Y}$ & $\mathrm{N}$ & $\mathrm{Y}$ & $\mathrm{N}$ & $\mathrm{Y}$ & $\mathrm{N}$ & Fair \\
\hline Gagnon 2004 & $\mathrm{Y}$ & $\mathrm{Y}$ & $\mathrm{N}$ & $\mathrm{Y}$ & $\mathrm{N}$ & $\mathrm{Y}$ & $\mathrm{Y}$ & $\mathrm{Y}$ & $\mathrm{Y}$ & $\mathrm{N}$ & $\mathrm{Y}$ & $\mathrm{N}$ & $\mathrm{Y}$ & $\mathrm{N}$ & Fair \\
\hline Bunton 2004 & $\mathrm{Y}$ & $\mathrm{Y}$ & $\mathrm{N}$ & $\mathrm{Y}$ & $\mathrm{N}$ & $Y$ & $\mathrm{Y}$ & $\mathrm{N}$ & $\mathrm{Y}$ & $\mathrm{N}$ & $\mathrm{Y}$ & $\mathrm{N}$ & $\mathrm{Y}$ & $\mathrm{N}$ & Fair \\
\hline Katsaro 2004 & $\mathrm{Y}$ & $\mathrm{Y}$ & $\mathrm{N}$ & $\mathrm{Y}$ & $\mathrm{N}$ & $\mathrm{Y}$ & $\mathrm{Y}$ & $\mathrm{N}$ & $\mathrm{Y}$ & $\mathrm{N}$ & $\mathrm{Y}$ & $\mathrm{N}$ & $\mathrm{Y}$ & $\mathrm{N}$ & Fair \\
\hline Cicolin 2004 & $\mathrm{Y}$ & $\mathrm{Y}$ & $\mathrm{N}$ & $\mathrm{Y}$ & $\mathrm{N}$ & $\mathrm{Y}$ & $\mathrm{Y}$ & $\mathrm{N}$ & $\mathrm{Y}$ & $\mathrm{N}$ & $\mathrm{Y}$ & $\mathrm{N}$ & $\mathrm{Y}$ & $\mathrm{Y}$ & Fair \\
\hline Roth 2003 & $\mathrm{Y}$ & $\mathrm{Y}$ & $\mathrm{N}$ & $\mathrm{Y}$ & $\mathrm{N}$ & $\mathrm{Y}$ & $\mathrm{Y}$ & $\mathrm{N}$ & $\mathrm{Y}$ & $\mathrm{N}$ & $\mathrm{Y}$ & $\mathrm{N}$ & Y & $\mathrm{N}$ & Fair \\
\hline Fimbel 2003 & $\mathrm{Y}$ & $\mathrm{Y}$ & $\mathrm{N}$ & $\mathrm{Y}$ & $\mathrm{N}$ & $\mathrm{Y}$ & $\mathrm{Y}$ & $\mathrm{N}$ & $\mathrm{Y}$ & $\mathrm{N}$ & $\mathrm{Y}$ & $\mathrm{N}$ & $\mathrm{Y}$ & $\mathrm{N}$ & Fair \\
\hline Zeuner 2003 & $\mathrm{Y}$ & $\mathrm{Y}$ & $\mathrm{N}$ & $\mathrm{N}$ & $\mathrm{N}$ & $\mathrm{Y}$ & $\mathrm{Y}$ & $\mathrm{N}$ & $\mathrm{Y}$ & $\mathrm{N}$ & $\mathrm{Y}$ & $\mathrm{N}$ & $\mathrm{Y}$ & $\mathrm{N}$ & Fair \\
\hline Kelly 2002 & $\mathrm{Y}$ & $\mathrm{Y}$ & $\mathrm{N}$ & $\mathrm{N}$ & $\mathrm{N}$ & $\mathrm{Y}$ & $\mathrm{Y}$ & $\mathrm{N}$ & $\mathrm{Y}$ & $\mathrm{N}$ & $\mathrm{Y}$ & $\mathrm{N}$ & $\mathrm{Y}$ & $\mathrm{N}$ & Fair \\
\hline Martin 2002 & $\mathrm{Y}$ & $\mathrm{Y}$ & $\mathrm{N}$ & $\mathrm{Y}$ & $\mathrm{N}$ & $\mathrm{Y}$ & $\mathrm{Y}$ & $\mathrm{N}$ & $\mathrm{Y}$ & $\mathrm{N}$ & $\mathrm{Y}$ & $\mathrm{N}$ & $\mathrm{Y}$ & & Fair \\
\hline Young 2002 & $\mathrm{Y}$ & $\mathrm{Y}$ & $\mathrm{N}$ & $\mathrm{Y}$ & $\mathrm{N}$ & $\mathrm{Y}$ & $\mathrm{Y}$ & $\mathrm{Y}$ & $\mathrm{Y}$ & $\mathrm{N}$ & $\mathrm{N}$ & $\mathrm{N}$ & $\mathrm{Y}$ & $\mathrm{N}$ & Fair \\
\hline Moller 2002 & $\mathrm{Y}$ & $\mathrm{Y}$ & $\mathrm{N}$ & $\mathrm{Y}$ & $\mathrm{N}$ & $\mathrm{Y}$ & $\mathrm{Y}$ & $\mathrm{N}$ & $\mathrm{Y}$ & $\mathrm{N}$ & $\mathrm{Y}$ & $\mathrm{N}$ & $\mathrm{Y}$ & $\mathrm{N}$ & Fair \\
\hline Gagnon 2002 & $\mathrm{Y}$ & $\mathrm{Y}$ & $\mathrm{N}$ & $\mathrm{Y}$ & $\mathrm{N}$ & $\mathrm{Y}$ & $\mathrm{Y}$ & $\mathrm{N}$ & $\mathrm{Y}$ & $\mathrm{N}$ & $\mathrm{Y}$ & $\mathrm{N}$ & $\mathrm{Y}$ & $\mathrm{N}$ & Fair \\
\hline Ferrarin 2002 & $\mathrm{Y}$ & $\mathrm{Y}$ & $\mathrm{N}$ & $\mathrm{N}$ & $\mathrm{N}$ & $Y$ & $\mathrm{Y}$ & $\mathrm{N}$ & $\mathrm{Y}$ & $\mathrm{Y}$ & $\mathrm{Y}$ & $\mathrm{Y}$ & $\mathrm{Y}$ & $\mathrm{Y}$ & Fair \\
\hline Haapaniemi 2001 & $\mathrm{Y}$ & $\mathrm{Y}$ & $\mathrm{N}$ & $\mathrm{Y}$ & $\mathrm{N}$ & $\mathrm{Y}$ & $\mathrm{Y}$ & $\mathrm{N}$ & $\mathrm{Y}$ & $\mathrm{N}$ & $\mathrm{N}$ & $\mathrm{N}$ & $\mathrm{Y}$ & $\mathrm{N}$ & Fair \\
\hline $\begin{array}{l}\text { Wenzelrburger } \\
2000\end{array}$ & $\mathrm{Y}$ & $\mathrm{Y}$ & $\mathrm{N}$ & $\mathrm{Y}$ & $\mathrm{N}$ & $\mathrm{Y}$ & $\mathrm{Y}$ & $\mathrm{N}$ & $\mathrm{Y}$ & $\mathrm{N}$ & $\mathrm{Y}$ & $\mathrm{N}$ & $\mathrm{Y}$ & $\mathrm{N}$ & Fair \\
\hline Antal 2000 & $\mathrm{Y}$ & $\mathrm{Y}$ & $\mathrm{N}$ & $\mathrm{Y}$ & $\mathrm{N}$ & $\mathrm{Y}$ & $\mathrm{Y}$ & $\mathrm{N}$ & $\mathrm{Y}$ & $\mathrm{N}$ & $\mathrm{Y}$ & $\mathrm{N}$ & $\mathrm{Y}$ & $\mathrm{N}$ & Fair \\
\hline
\end{tabular}




\begin{tabular}{|c|c|c|c|c|c|c|c|c|c|c|c|c|c|c|c|}
\hline Tanaka 2000 & $\mathrm{Y}$ & $\mathrm{Y}$ & $\mathrm{N}$ & $\mathrm{Y}$ & $\mathrm{N}$ & $\mathrm{Y}$ & $\mathrm{Y}$ & $\mathrm{N}$ & $\mathrm{Y}$ & $\mathrm{N}$ & $\mathrm{Y}$ & $\mathrm{N}$ & $\mathrm{Y}$ & $\mathrm{N}$ & Fair \\
\hline $\begin{array}{l}\text { Van Emmerik } \\
1999\end{array}$ & $\mathrm{Y}$ & $\mathrm{Y}$ & $\mathrm{N}$ & $\mathrm{Y}$ & $\mathrm{N}$ & $\mathrm{Y}$ & $Y$ & $\mathrm{Y}$ & $Y$ & $\mathrm{~N}$ & $\mathrm{Y}$ & $\mathrm{N}$ & $\mathrm{Y}$ & $\mathrm{Y}$ & Fair \\
\hline Oka 1997 & $\mathrm{Y}$ & $\mathrm{Y}$ & $\mathrm{N}$ & $\mathrm{Y}$ & $\mathrm{N}$ & $\mathrm{Y}$ & $\mathrm{Y}$ & $\mathrm{N}$ & $\mathrm{Y}$ & $\mathrm{N}$ & $\mathrm{Y}$ & $\mathrm{N}$ & $\mathrm{Y}$ & $\mathrm{N}$ & Fair \\
\hline Hawkes 1997 & $\mathrm{Y}$ & $\mathrm{Y}$ & $\mathrm{N}$ & $\mathrm{Y}$ & $\mathrm{N}$ & $\mathrm{Y}$ & $\mathrm{Y}$ & $\mathrm{N}$ & $\mathrm{Y}$ & $\mathrm{N}$ & $\mathrm{Y}$ & $\mathrm{N}$ & $\mathrm{Y}$ & $\mathrm{N}$ & Fair \\
\hline Sagliocco 1997 & $\mathrm{Y}$ & $\mathrm{Y}$ & $\mathrm{N}$ & $\mathrm{Y}$ & $\mathrm{N}$ & $\mathrm{Y}$ & $\mathrm{Y}$ & $\mathrm{N}$ & $\mathrm{Y}$ & $\mathrm{N}$ & $\mathrm{Y}$ & $\mathrm{N}$ & $\mathrm{Y}$ & $\mathrm{N}$ & Fair \\
\hline Green 1996 & $\mathrm{Y}$ & $\mathrm{Y}$ & $\mathrm{N}$ & $\mathrm{Y}$ & $\mathrm{N}$ & $\mathrm{Y}$ & $\mathrm{Y}$ & $\mathrm{N}$ & $\mathrm{Y}$ & $\mathrm{N}$ & $\mathrm{Y}$ & $\mathrm{N}$ & $\mathrm{Y}$ & $\mathrm{N}$ & Fair \\
\hline Kim 1995 & $\mathrm{Y}$ & $\mathrm{Y}$ & $\mathrm{N}$ & $\mathrm{Y}$ & $\mathrm{N}$ & $\mathrm{Y}$ & $\mathrm{Y}$ & $\mathrm{N}$ & $\mathrm{Y}$ & $\mathrm{N}$ & $\mathrm{Y}$ & $\mathrm{N}$ & $\mathrm{Y}$ & $\mathrm{N}$ & Fair \\
\hline Peppe 1995 & $\mathrm{Y}$ & $\mathrm{Y}$ & $\mathrm{N}$ & $\mathrm{Y}$ & $\mathrm{N}$ & $\mathrm{Y}$ & $\mathrm{Y}$ & $\mathrm{N}$ & $\mathrm{Y}$ & $\mathrm{N}$ & $\mathrm{Y}$ & $\mathrm{N}$ & $\mathrm{Y}$ & $\mathrm{N}$ & Fair \\
\hline $\begin{array}{l}\text { Bodis-Wollner } \\
1995\end{array}$ & $\mathrm{Y}$ & $\mathrm{Y}$ & $\mathrm{N}$ & $\mathrm{Y}$ & $\mathrm{N}$ & $\mathrm{Y}$ & $\mathrm{Y}$ & $\mathrm{N}$ & $\mathrm{Y}$ & $\mathrm{N}$ & $\mathrm{Y}$ & $\mathrm{N}$ & $\mathrm{Y}$ & $\mathrm{N}$ & Fair \\
\hline Pekkonen 1995 & $\mathrm{Y}$ & $\mathrm{Y}$ & $\mathrm{N}$ & $\mathrm{Y}$ & $\mathrm{N}$ & $\mathrm{Y}$ & $\mathrm{Y}$ & $\mathrm{N}$ & $\mathrm{Y}$ & $\mathrm{N}$ & $\mathrm{Y}$ & $\mathrm{N}$ & $\mathrm{Y}$ & $\mathrm{N}$ & Fair \\
\hline Johnson 1994 & $\mathrm{Y}$ & $\mathrm{Y}$ & $\mathrm{N}$ & $\mathrm{N}$ & $\mathrm{N}$ & $\mathrm{Y}$ & $\mathrm{Y}$ & $\mathrm{N}$ & $\mathrm{Y}$ & $\mathrm{N}$ & $\mathrm{Y}$ & $\mathrm{N}$ & $\mathrm{Y}$ & $\mathrm{N}$ & Fair \\
\hline Vieregge 1994 & $\mathrm{Y}$ & Y & $\mathrm{N}$ & $\mathrm{Y}$ & $\mathrm{N}$ & $\mathrm{Y}$ & $Y$ & $\mathrm{~N}$ & $Y$ & $\mathrm{~N}$ & $\mathrm{Y}$ & $\mathrm{N}$ & $\mathrm{Y}$ & $\mathrm{N}$ & Fair \\
\hline Svensonn 1993 & $\mathrm{Y}$ & $\mathrm{Y}$ & $\mathrm{N}$ & $\mathrm{Y}$ & $\mathrm{N}$ & $\mathrm{N}$ & $\mathrm{Y}$ & $\mathrm{N}$ & $\mathrm{Y}$ & $\mathrm{N}$ & $\mathrm{Y}$ & $\mathrm{N}$ & $\mathrm{Y}$ & $\mathrm{N}$ & Fair \\
\hline Doan 2010 & $\mathrm{Y}$ & $\mathrm{Y}$ & $\mathrm{N}$ & $\mathrm{N}$ & $\mathrm{N}$ & $\mathrm{Y}$ & $\mathrm{Y}$ & $\mathrm{N}$ & $\mathrm{Y}$ & $\mathrm{N}$ & $\mathrm{Y}$ & $\mathrm{N}$ & $\mathrm{Y}$ & $\mathrm{N}$ & Poor \\
\hline Uemura 2009 & $\mathrm{Y}$ & $\mathrm{Y}$ & $\mathrm{N}$ & $\mathrm{Y}$ & $\mathrm{N}$ & $\mathrm{Y}$ & $\mathrm{Y}$ & $\mathrm{Y}$ & $\mathrm{Y}$ & $\mathrm{N}$ & $\mathrm{Y}$ & $\mathrm{N}$ & $\mathrm{Y}$ & $\mathrm{N}$ & Poor \\
\hline Diederich 2009 & $\mathrm{Y}$ & $\mathrm{Y}$ & $\mathrm{N}$ & $\mathrm{N}$ & $\mathrm{N}$ & $\mathrm{Y}$ & $\mathrm{Y}$ & $\mathrm{N}$ & $\mathrm{Y}$ & $\mathrm{N}$ & $\mathrm{Y}$ & $\mathrm{N}$ & $\mathrm{Y}$ & $\mathrm{N}$ & Poor \\
\hline Perez-1loret 2009 & $\mathrm{Y}$ & $\mathrm{Y}$ & $\mathrm{N}$ & $\mathrm{N}$ & $\mathrm{N}$ & $\mathrm{Y}$ & $\mathrm{Y}$ & $\mathrm{N}$ & $\mathrm{Y}$ & $\mathrm{N}$ & $\mathrm{Y}$ & $\mathrm{N}$ & $\mathrm{Y}$ & $\mathrm{N}$ & Poor \\
\hline Norlinah 2009 & $\mathrm{Y}$ & $\mathrm{Y}$ & $\mathrm{N}$ & $\mathrm{N}$ & $\mathrm{N}$ & Y & Y & $\mathrm{N}$ & $Y$ & $\mathrm{~N}$ & $\mathrm{Y}$ & $\mathrm{N}$ & $\mathrm{Y}$ & $\mathrm{N}$ & Poor \\
\hline Popovic 2008 & $\mathrm{Y}$ & $\mathrm{Y}$ & $\mathrm{N}$ & $\mathrm{N}$ & $\mathrm{N}$ & $\mathrm{Y}$ & $\mathrm{Y}$ & $\mathrm{N}$ & $\mathrm{Y}$ & $\mathrm{N}$ & $\mathrm{Y}$ & $\mathrm{N}$ & $\mathrm{Y}$ & $\mathrm{N}$ & Poor \\
\hline Bleuse 2008 & $\mathrm{Y}$ & $\mathrm{Y}$ & $\mathrm{N}$ & $\mathrm{N}$ & $\mathrm{N}$ & $\mathrm{Y}$ & $\mathrm{Y}$ & $\mathrm{N}$ & $\mathrm{Y}$ & $\mathrm{N}$ & $\mathrm{Y}$ & $\mathrm{N}$ & $\mathrm{Y}$ & $\mathrm{N}$ & Poor \\
\hline Oka 2003 & $\mathrm{Y}$ & $\mathrm{N}$ & $\mathrm{N}$ & $\mathrm{N}$ & $\mathrm{N}$ & $\mathrm{Y}$ & $\mathrm{Y}$ & $\mathrm{N}$ & $\mathrm{Y}$ & $\mathrm{N}$ & $\mathrm{Y}$ & $\mathrm{N}$ & $\mathrm{Y}$ & $\mathrm{N}$ & Poor \\
\hline Vaillancourt 2000 & $\mathrm{Y}$ & $\mathrm{Y}$ & $\mathrm{N}$ & $\mathrm{N}$ & $\mathrm{N}$ & $\mathrm{Y}$ & $\mathrm{Y}$ & $\mathrm{N}$ & $\mathrm{Y}$ & $\mathrm{N}$ & $\mathrm{Y}$ & $\mathrm{N}$ & $\mathrm{Y}$ & $\mathrm{N}$ & Poor \\
\hline Mastrocola 1999 & $\mathrm{Y}$ & Y & $\mathrm{N}$ & $\mathrm{Y}$ & $\mathrm{N}$ & $\mathrm{Y}$ & $\mathrm{Y}$ & $\mathrm{N}$ & $Y$ & $\mathrm{Y}$ & $\mathrm{Y}$ & $\mathrm{N}$ & $Y$ & $\mathrm{~N}$ & Poor \\
\hline Buttner 1996 & $\mathrm{Y}$ & $\mathrm{Y}$ & $\mathrm{N}$ & $\mathrm{Y}$ & $\mathrm{N}$ & $\mathrm{Y}$ & $\mathrm{Y}$ & $\mathrm{N}$ & $Y$ & $\mathrm{~N}$ & $\mathrm{Y}$ & $\mathrm{N}$ & $\mathrm{Y}$ & $\mathrm{N}$ & Poor \\
\hline
\end{tabular}

Questions

1. Was the research question or objective in this paper clearly stated?

2. Was the study population clearly specified and defined?

3. Was the participation rate of eligible persons at least $50 \%$ ? 
4. Were all the subjects selected or recruited from the same or similar populations (including the same time period)? Were inclusion and exclusion criteria for being in the study prespecified and applied uniformly to all participants?

5. Was a sample size justification, power description, or variance and effect estimates provided?

6. For the analyses in this paper, were the exposure(s) of interest measured prior to the outcome(s) being measured?

7. Was the timeframe sufficient so that one could reasonably expect to see an association between exposure and outcome if it existed?

8. For exposures that can vary in amount or level, did the study examine different levels of the exposure as related to the outcome (e.g., categories of exposure, or exposure measured as continuous variable)?

9. Were the exposure measures (independent variables) clearly defined, valid, reliable, and implemented consistently across all study participants?

10. Was the exposure(s) assessed more than once over time?

11. Were the outcome measures (dependent variables) clearly defined, valid, reliable, and implemented consistently across all study participants?

12. Were the outcome assessors blinded to the exposure status of participants?

13. Was loss to follow-up after baseline $20 \%$ or less?

14. Were key potential confounding variables measured and adjusted statistically for their impact on the relationship between exposure(s) and outcome(s)? 